Research article

urn:lsid:zoobank.org:pub:A3CE68AA-C5C6-40B7-B57C-6EF6D949149B

\title{
Revision of the Astyanax orthodus species-group (Teleostei: Characidae) with descriptions of three new species
}

\author{
Raquel I. RUIZ-C. 1,*, César ROMÁN-VALENCIA², Donald C. TAPHORN ${ }^{3}$, \\ Paulo A. BUCKUP ${ }^{4} \&$ Hernán ORTEGA ${ }^{5}$ \\ ${ }^{1,2,3}$ Laboratorio de Ictiología, Universidad del Quindío, P.O. Box. 2639, Armenia, Quindío, Colombia. \\ ${ }^{3} 1822$ North Charles Street, Belleville, Illinois, 62221, USA. \\ ${ }^{4}$ Dept. de Vertebrados, Museu Nacional, Universidade Federal do Rio de Janeiro, RJ, \\ Quinta da Boa Vista, 20940-040 Rio de Janeiro, RJ, Brazil. \\ ${ }^{5}$ Departamento de Ictiología-Museo de Historia Natural, Universidad Nacional Mayor de San Marcos, \\ Apartado 11434, Lima 14, Peru. \\ *Corresponding autor: zutana_1@yahoo.com \\ ${ }^{2}$ Email: ceroman@uniquindio.edu.co \\ 32Email: taphorn@gmail.com \\ ${ }^{4}$ Email: buckup@acd.ufrj.br \\ ${ }^{5}$ Email: hortega.musm@gmail.com

\begin{abstract}
${ }^{1}$ urn:1sid:zoobank.org:author:293A6F02-F383-4948-BEF8-8F715BCBAD49
${ }^{2}$ urn:lsid:zoobank.org:author:3A1C25DF-B824-43D0-AE1F-0C78D991109C

${ }^{3}$ urn:lsid:zoobank.org:author:8FBA4B3B-6E8F-497B-AD3B-0AA59C9109EB

${ }^{4}$ urn:1sid:zoobank.org:author:3C9E8AE8-5B7B-47CD-9FBA-760CAFCF0386

${ }^{5}$ urn:1sid:zoobank.org:author:9DD0B470-D023-41BF-A39D-6578954EB663
\end{abstract}

\begin{abstract}
The Astyanax orthodus species-group includes nine species: Astyanax boliviensis sp. nov., A. bopiensis nom. nov., A. embera sp. nov., A. gandhiae sp. nov., A. moorii comb. nov., A. orthodus, A. superbus, A. villwocki and A. yariguies comb. nov. The group is diagnosed by the presence of a series of pinnate-shaped marks (chevrons) located along the lateral midline, which extends from the humeral region to the caudal peduncle. Astyanax bopiensis nom. nov. is proposed as a substitute name for Astyanacinus multidens, which, along with Astyanax yariguies comb. nov., we reassign to Astyanax. We also propose the synonymy of Astyanacinus with Astyanax. The members of the A. orthodus speciesgroup are distributed in northwestern South America, occurring in the Patia River drainage (A. embera sp. nov.) of the Pacific coast of Colombia, the Atrato River Basin (A. orthodus), the Magdalena River Basin (A. yariguies comb. nov.) of Caribbean Colombia, streams of the southern flank of the Andes of the Orinoco Basin in Venezuela (A. superbus), in the upper Amazon River Basin of Colombia, Ecuador and Peru (A. villwocki, A. gandhiae sp. nov.), from the upper Paraguay River (A. moorii comb. nov.), the Madidi and Mamore Rivers, Bolivia (A. boliviensis sp. nov. and A. bopiensis nom. nov.). All species currently included in Astyanacinus are reassigned to the Astyanax orthodus species-group.
\end{abstract}

Keywords. Characid fish, characiforms, taxonomy. 
Ruiz-C. R.I., Román-Valencia C., Taphorn D.C., Buckup P.A. \& Ortega H. 2018. Revision of the Astyanax orthodus species-group (Teleostei: Characidae) with descriptions of three new species. European Journal of Taxonomy 402 : 1-45. https://doi.org/10.5852/ejt.2018.402

\section{Introduction}

Astyanax Baird \& Girard, 1854 is one of the largest genera of the Neotropical freshwater fish family Characidae. It currently includes more than 100 species, and continues to provide taxonomic and phylogenetic challenges (Kavalco et al. 2009; Bertaco \& Lucena 2010; Ruiz-C. et al. 2011; SchmitterSoto 2016). The species occupy a wide diversity of niches and aquatic environments ranging from the high Andes to lowland coastal swamps and subterranean environments and are widely distributed from Texas, USA, to Argentina (Garutti \& Britski 1997; Ruiz-C. \& Cipriani 2007; Vari \& Castro 2007; Garutti \& Langeani 2009; Wilkens \& Streker 2003; Marinho et al. 2015; Schmitter-Soto 2016). The numerous species and abundant populations of Astyanax exemplify the taxonomic diversity of this genus with high morphological similarities and supposedly widespread geographical distributions.

Astyanax was included in a comprehensive phylogenetic analysis based on morphological characters and was found to include at least nine independent clades (Mirande 2010), making Astyanax paraphyletic if recognized (Schmitter-Soto 2016). Species of Astyanax have also been included in molecular studies (Calcagnotto et al. 2005; Javonillo et al. 2010; Oliveira et al. 2011), which corroborate uncertainty about the limits and monophyly of the genus.

Poecilurichthys Gill, 1858, a taxon based on the type species Astyanax brevoortii (Gill, 1858) from the western side of the Island of Trinidad, was considered by Eigenmann (1910) as a subgenus of Astyanax. Fourteen taxa assigned to Poecilurichthys by Eigenmann (1921) are still valid as species of Astyanax. Ten of these species [Astyanax anterior Eigenmann, 1908, A. abramis (Jenyns, 1842), A. bimaculatus (Linnaeus, 1758), A. bourgeti Eigenmann, 1908, A. janeiroensis Eigenmann, 1908, A. goyacensis Eigenmann, 1908, A. lacustris (Lütken, 1875), A. novae (Eigenmann, 1911), A. orthodus Eigenmann, 1907 and A. rupununi (Fowler, 1914)] share a pigmentation pattern of melanophores in the humeral region of the body that forms a horizontally-ovate blotch (Mirande 2010: character 341). This pattern is present in 15 other species of Astyanax described after the taxonomic revision by Eigenmann (1921) (Astyanax poetzschkei Ahl, 1932; A. superbus Myers, 1942; A. asuncionensis Géry, 1972; A. leopoldi Géry, Planquette \& Le Bail, 1988; A. maculisquamis Garutti \& Britski, 1997; A. unitaeniatus Garutti, 1998; A. argyrimarginatus Garutti, 1999; A. villwocki Zarske \& Géry, 1999; A. altiparanae Garutti \& Britski, 2000; A. clavitaeniatus Garutti, 2003; A. siapae Garutti, 2003; A. bockmanni Vari \& Castro, 2007; A. utiariti Bertaco \& Garutti, 2007; A. xavante Garutti \& Venere, 2009 and A. serratus Garavello \& Sampaio, 2010).

Among these species, young specimens of Astyanax orthodus frequently have a pigmentation pattern of chevrons that are formed by a series of dark lines along myosepta separating the myotomes near the midline of the sides of the body (Eigenmann 1921). These chevron marks are also found in Astyanax superbus Myers, 1942 and A. villwocki Zarske \& Géry, 1999.

The series of chevrons is also found in some species assigned to Astyanacinus (Eigenmann 1907), a genus closely related to Astyanax (Mirande 2010; D’Agosta 2011), that differs only in the large size of the mouth gape. As defined by Eigenmann (1927), Astyanacinus has a longer maxilla and it does not form an angle with the premaxilla (D'Agosta 2011), but this character state is also present in Astyanax orthodus, A. superbus and A. villwocki (personal observation Ruiz-C).

Five species have been assigned to Astyanacinus: Astyanacinus goyanensis (Miranda-Ribeiro, 1944) (upper Tocantins River Basin), A. moorii (Boulenger, 1892) comb. nov. (upper Paraguay River Basin), 
A. multidens Pearson, 1924 (upper Madeira River Basin), A. platensis (Messner, 1962) (La Plata River Basin) and A. yariguies Torres-Mejía et al., 2012 (Magdalena River Basin). However, a re-examination and consideration of the characters supposedly diagnostic for the genus Astyanacinus has led to the relocation of $A$. goyanensis to the genus Astyanax by Bertaco et al. (2010) and A. platensis to the genus Oligosarcus Günther, 1864 by Mirande et al. (2011). Other species of Astyanacinus (A. moorii comb. nov., A. multidens and A. yariguies) share apomorphic features with the "Astyanax bimaculatusgroup" (Mirande 2010). The presence of chevron-shaped marks on the flanks is a character shared with Astyanax superbus and Hyphessobrycon bifasciatus Ellis, 1911 among other species that could relate Astyanacinus to either the Astyanax clade or the Hyphessobrycon luetkeni clade (Mirande 2010).

A phylogenetic analysis of the species of Astyanacinus (D'Agosta 2011) supported the monophyly of the genus, with the inclusion of some species of Astyanax such as A. orthodus and A. superbus. However, evidence also exists showing a relationship of these species with others still included in Astyanax and even with species of the A. bimaculatus species-group (Calcagnotto et al. 2005; Javonillo et al. 2010; Mirande 2010; D’Agosta 2011).

In this study, species are diagnosed as members of the Astyanax orthodus species-group based on the presence of a series of dark chevron-shaped marks present along the sides of the body, positioned both dorsal and ventral to the horizontal myoseptum from the humeral region to the caudal peduncle. They also have a foramen present between the second and third teeth of the inner series of the premaxilla,and tubules for passage of blood vessels on the lamellar portion of the maxilla with the anterior branch running parallel to the anterior margin of the maxilla and extending for one third of its length. These characters support recognition of a group including the members of the Astyanax orthodus speciesgroup: A. orthodus, A. superbus, A. villwocki and species previously included in Astyanacinus (A. moorii comb. nov., A. multidens (= Astyanax bopiensis nom. nov.) and A. yariguies comb. nov.). In this paper, we present a systematic revision of the Astyanax orthodus species-group and describe three new species.

\section{Material and methods}

Morphometric data were recorded from type and non-type material of Astyanax listed in the Material examined sections (below). Comparative material (see Appendix) was made available from institutions in Argentina (ILPLA, MLP), Bolivia (CBF, UMSS), Brazil (MNRJ, MCP), Colombia (IAvHP, ICN-MHN, IUQ), France (MNHM), Mexico (CNPE-IBUNAM), Peru (MUSM acronym of MHN.UNMSM), USA (INHS, AMNH, AUM, UF) and Venezuela (MCNG, MBUCV). Acronyms used follow Sabaj-Pérez (2016).

Osteological characters were observed in cleared and stained (C\&S) specimens prepared with methods outlined in Taylor \& Van Dyke (1985); only adult specimens were cleared and stained to avoid confounding effects of ontogenetic variation in the degree of ossification. The total vertebral count includes those of the Weberian apparatus. Illustrations of diagnostic characters for each species were made from adult specimens. Bone nomenclature follows Weitzman (1962), as modified by Mirande (2010) and Mirande et al. (2013).

Morphometric and meristic data follow Vari \& Siebert (1990), Fink \& Weitzman (1974) and Román-Valencia (2003), except for head length, which was measured from the anterior tip of the snout to the posterior margin of the subopercle and interorbital width, which was measured at the level of the epiphyseal bar. Measurements were collected using digital calipers with a precision of $0.1 \mathrm{~mm}$, except for those of the type material (i.e., Tetragonopterus moorii Boulenger, 1892), which were processed using the software program Image J ver. 1.48 (Schneider et al. 2012). The mean and range of variation for 23 morphometric data are expressed as percentages of standard or head length. Meristic data and sexually dimorphic characters are followed by the number of individuals examined in parentheses. In material examined, the number of specimens inspected both in alcohol and cleared and stained (C\&S) is given 
after the lot number, followed by the minimum and maximum standard length. In the descriptions, the number of individuals recorded for each count follows that value in parentheses. In the tables, SD stands for 'standard deviation', $\mathrm{H}$ for holotype, $\mathrm{L}$ for lectotype and $\mathrm{N}$ for the number of specimens measured.

\section{Results}

Order Characiformes Goodrich, 1909

Family Characidae Latreille, 1825

Genus Astyanax Baird \& Girard, 1854

Astyanax orthodus Eigenmann, 1907 species-group

Some species of Astyanax exhibit a horizontally elongate oval humeral spot with sharp, well delimited margins, which is bordered anteriorly and posteriorly by light regions mostly devoid of melanophores (bimaculatus group). In this study we have observed that the different layers of pigment that form the humeral spot(s), have differing degrees of development and structure that are independent of each other (Fig. 1). We found brown melanophores distributed in a thin superficial layer of the epithelium (Layer 1, Fig. 1) and another deeper layer that consists of dark melanophores (Layer 2, Fig. 1). In some species with a horizontally ovate humeral spot there may be subtle variation in this character, but they retain the basic humeral pigmentation pattern, namely, the pigment model of the humeral spot described for the orthodus group follows the general pattern of the bimaculatus group, however, in the orthodus group the humeral spot has four vertices that give it the shape of a polygon.

\section{Key to the species of the Astyanax orthodus species-group}

1. Predorsal midline with a continuous series of scales covering more than three quarters of the distance between the posterior tip of supraoccipital spine and dorsal-fin origin ...2

- Predorsal midline irregularly scaled, with isolated scales or short series of medial scales alternating with scales that extend to or over the dorsal midline from the sides, especially along the posterior-most portion of the predorsal midline

2. Caudal-peduncle spot restricted to the caudal fin and adjacent caudal peduncle

- Caudal-peduncle spot not restricted to the caudal fin and adjacent caudal peduncle, extended anteriorly as a continuous dark line or stripe on side of body

3. Caudal-peduncle spot short, not extending anteriorly to a vertical through the posterior tip of the adipose fin; body with reticulate pattern from the dorsum to the pelvic region

A. yariguies (Torres-Mejía et al., 2012) (Magdalena River Basin)

- Caudal-peduncle spot long, extending anteriorly to or beyond a vertical through the posterior tip of the adipose fin; body with alternating light and dark horizontal wavy stripes

A. superbus Myers, 1942 (Orinoco River Basin)

4. Caudal-peduncle spot restricted to the midlateral axis of the body, not extending on to the dorsal and ventral margins of bases of caudal-fin rays

.................. orthodus Eigenmann, 1907 (Atrato River Basin, Caribbean Coast of Colombia)

- Caudal-peduncle spot extending on to the dorsal and ventral margins of the caudal- peduncle and the bases of caudal-fin rays ................ embera sp. nov. (Patía River Basin, Pacific Coast of Colombia)

5. Caudal-peduncle spot extending anteriorly as a dark line reaching second humeral spot ......... A. villwocki Zarske \& Géry, 1999 (Ucayali, Beni and Mamoré River drainages, Amazon River Basin)

- Caudal-peduncle spot not extending anteriorly beyond vertical through the anal-fin origin ........6 
6. Chevrons overlying lateral stripe short, their extensions not extending vertically from dorsal and ventral tips, occupying up to two series of scales above and below vertex of chevron; caudalpeduncle spot inconspicuous .......... gandhiae sp. nov. (Cenepa River drainage, upper Amazon)

- Chevrons overlying lateral stripe extended vertically by prolongations from dorsal and ventral tips over three horizontal rows of scales; caudal-peduncle spot conspicuous $\ldots \ldots \ldots \ldots \ldots \ldots \ldots \ldots . \ldots \ldots$

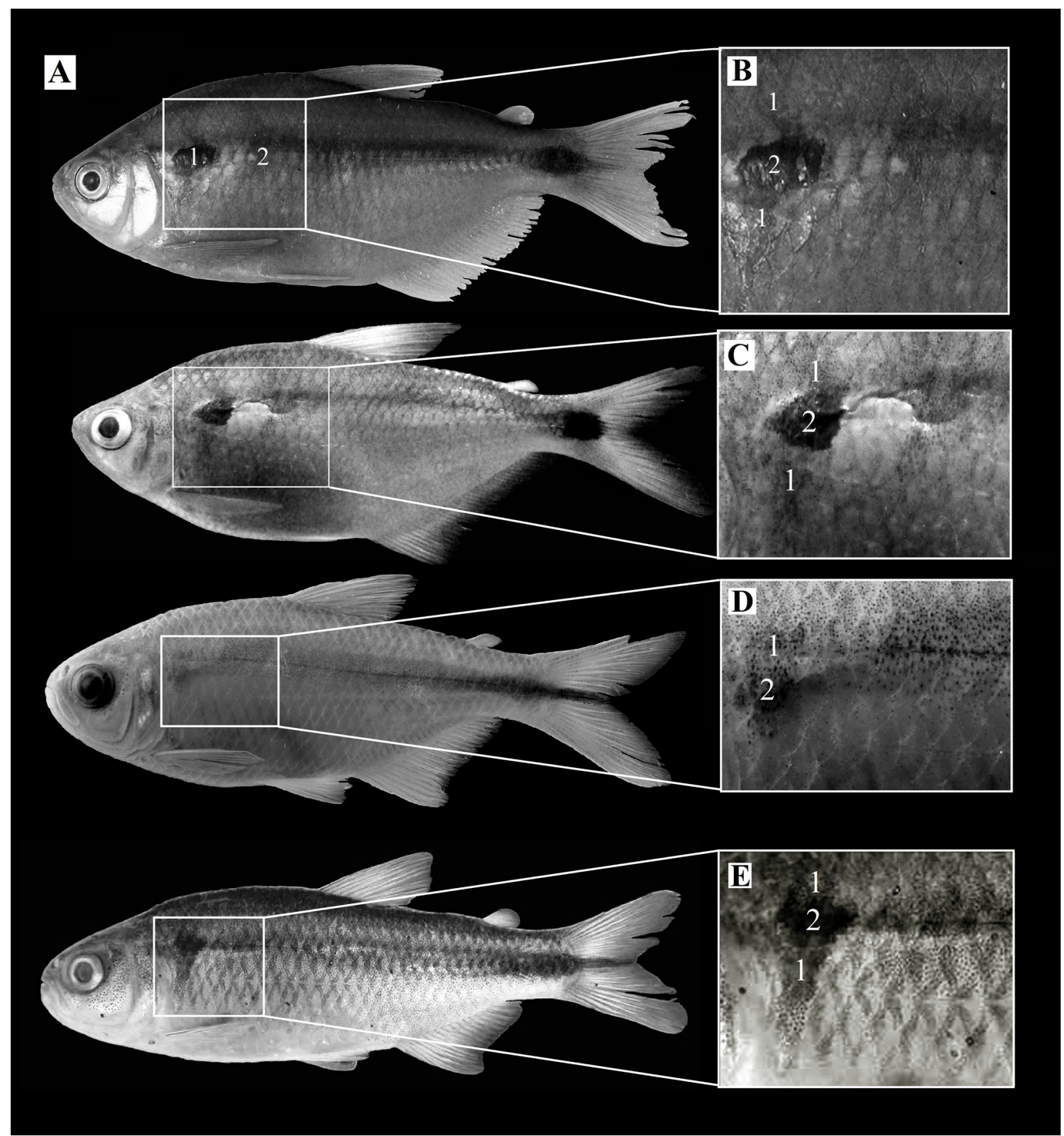

Fig. 1. A. Distribution of pigment in the humeral region of Astyanax species. B. A. bimaculatus (Linnaeus, 1758). C. A. caucanus (Steindachner, 1879). D. A. mexicanus (De Filippi, 1853). E. A. courensis Bertaco, Carvalho \& Jerep, 2010 (modified from Bertaco et al. 2010). The anterior humeral spot consists of two overlapping layers of pigment identified by numbers 1 and 2 (see Román-Valencia et al. 2015: fig. 1): 1. Diffuse vertical bar. 2. Horizontal spot with concentrated pigments. 
7. Teeth present along two-thirds of the length of the maxilla

A. bopiensis nom. nov. (Upper Madeira River drainage).

- Less than two-thirds of the length of the maxilla with teeth ..................................8

8. Lateral line with 43 or fewer scales

A. boliviensis sp. nov. (upper Madeira River drainage, Amazon River Basin)

- Lateral line with 44 or more scales ......A. moorii (Boulenger, 1892) comb. nov. (Upper Paraguay)

\author{
Astyanax embera sp. nov. \\ urn:1sid:zoobank.org:act:9B1792A8-70D6-4167-9136-0DD74844B040
}

Figs 2, 3B, 4, Table 1

\title{
Diagnosis
}

Astyanax embera sp. nov. is a member of the orthodus species-group of Astyanax, differing from other members of the group as follows: from $A$. villwocki, A. superbus, A. gandhiae sp. nov., A. bopiensis nom. nov., A. boliviensis sp. nov. and A. yariguies comb. nov. by the absence of a dark stripe on the sides of the body (vs dark lateral stripe present or anterior prolongation of the caudal peduncle spot extending anteriorly over the silvery lateral stripe). It differs from A. orthodus in having the caudal peduncle spot extending onto the ventral and dorsal margins of the caudal peduncle, covering 4-6 horizontal scale rows (vs covering 2-4 horizontal scale rows on the caudal peduncle, Fig. 3). It also differs from A. orthodus in having an unpigmented band across the anal-fin rays in both sexes (vs pigmentation uniform on analfin rays). It differs from $A$. moorii comb. nov. in the body depth $>39 \% \mathrm{SL}$ (vs $<39 \% \mathrm{SL}$ ), the dorsalpectoral fin distance $>40.5 \%$ SL (vs $<40.5 \% \mathrm{SL}$ ), maxilla length $<33.5 \% \mathrm{HL}$ (vs $>33.5 \% \mathrm{SH}$ ), upper jaw length $<32 \% \mathrm{HL}$ ( $\mathrm{vs}>47 \% \mathrm{SH}$ ) and by the number of lateral-line scales $36-41$ (vs $44-50$ ).

\section{Etymology}

The specific epithet embera is a noun in apposition and refers to the native Americans known as the Embera, who occupy the type locality of this new taxon.

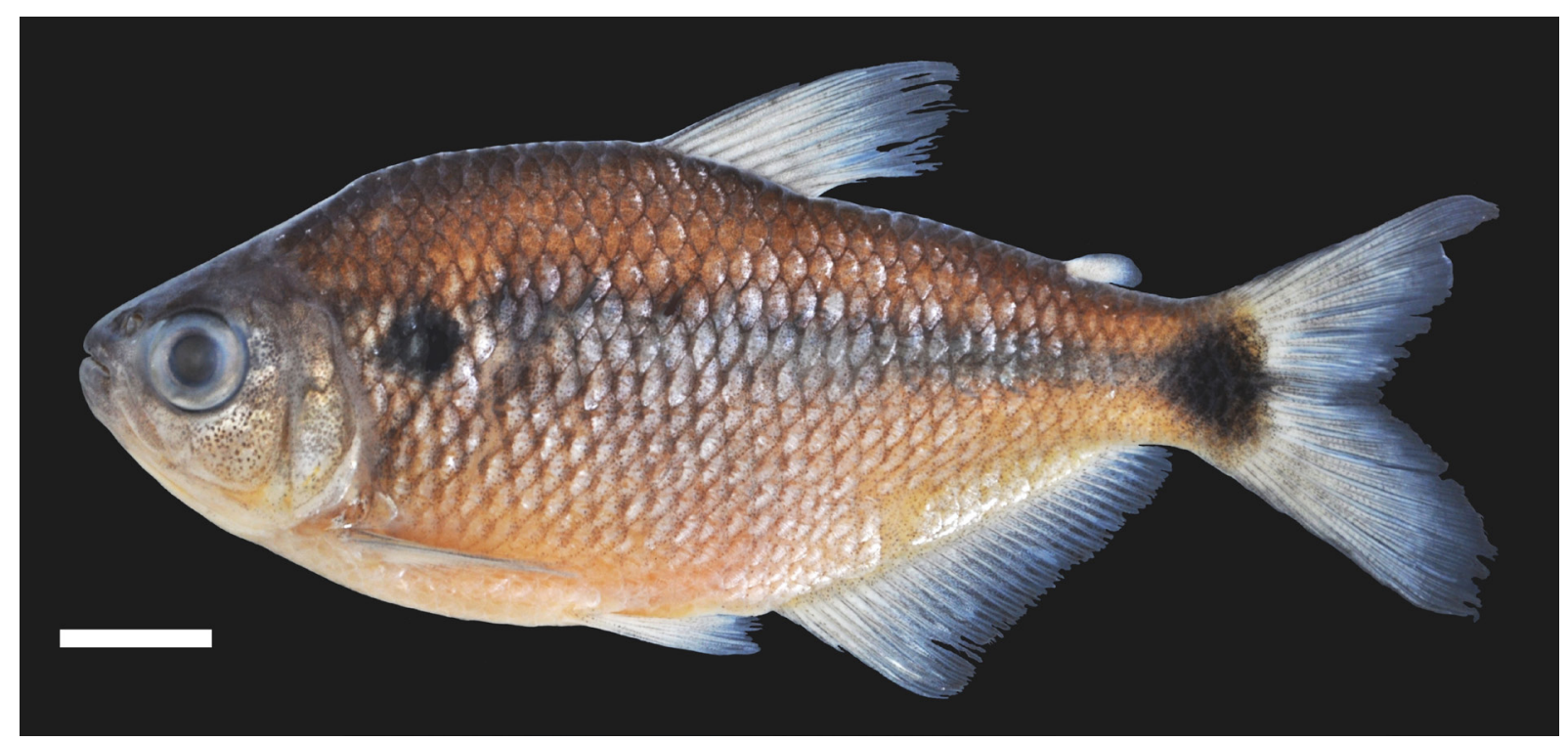

Fig. 2. Astyanax embera sp. nov., holotype, $83.0 \mathrm{~mm}$ SL, Telembí River at mouth of Yamunde River, $1 \mathrm{~km}$ below Barbacoas, Municipality of Barbacoas, Nariño, Pacific coast of Colombia (IUQ 3614). Scale bar $=1 \mathrm{~cm}$. 


\section{Material examined}

\section{Holotype}

COLOMBIA: 83.0 mm SL, Nariño Department, Barbacoas Municipality, Patía River Basin (Pacific Coast), Telembí River drainage, in Telembí River at mouth of Yamunde River, 1 km below Barbacoas, $01^{\circ} 39^{\prime} 56^{\prime \prime} \mathrm{N}, 78^{\circ} 09^{\prime} 12^{\prime \prime} \mathrm{W}, 61 \mathrm{~m}$ a.s.l. (IUQ 3614).

\section{Paratypes}

COLOMBIA: all from Nariño Department, Barbacoas Municipality, Patía River Basin, Telembi River

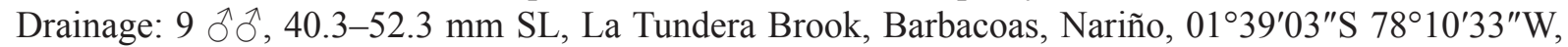
$41 \mathrm{~m}$ a.s.l. (IUQ 2264); 4 $\delta^{\lambda}, 5$ 우, $45.6-89.8 \mathrm{~mm} \mathrm{SL}, 4 \mathrm{C} \& \mathrm{~S}$ (sex unknown), 52.8-63.0 mm SL, same locality as for holotype (IUQ 701); 36 ๙ึ, 11우, 43.2-62.7 mm SL, 4C\&S (sex unknown), 39.2-

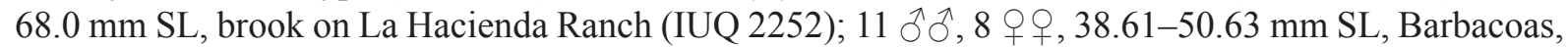
Yamunde River, $01^{\circ} 39^{\prime} 39^{\prime \prime} \mathrm{N}, 78^{\circ} 09^{\prime} 04^{\prime \prime} \mathrm{W}, 43 \mathrm{~m}$ a.s.l. (IUQ 2259); 3 đે $^{\lambda}, 52.6-85.5 \mathrm{~mm}$ SL, collected with holotype (IUQ 989); 1 specimen (sex unknown) C\&S, $53.8 \mathrm{~mm}$ SL, collected with holotype (IUQ1165).
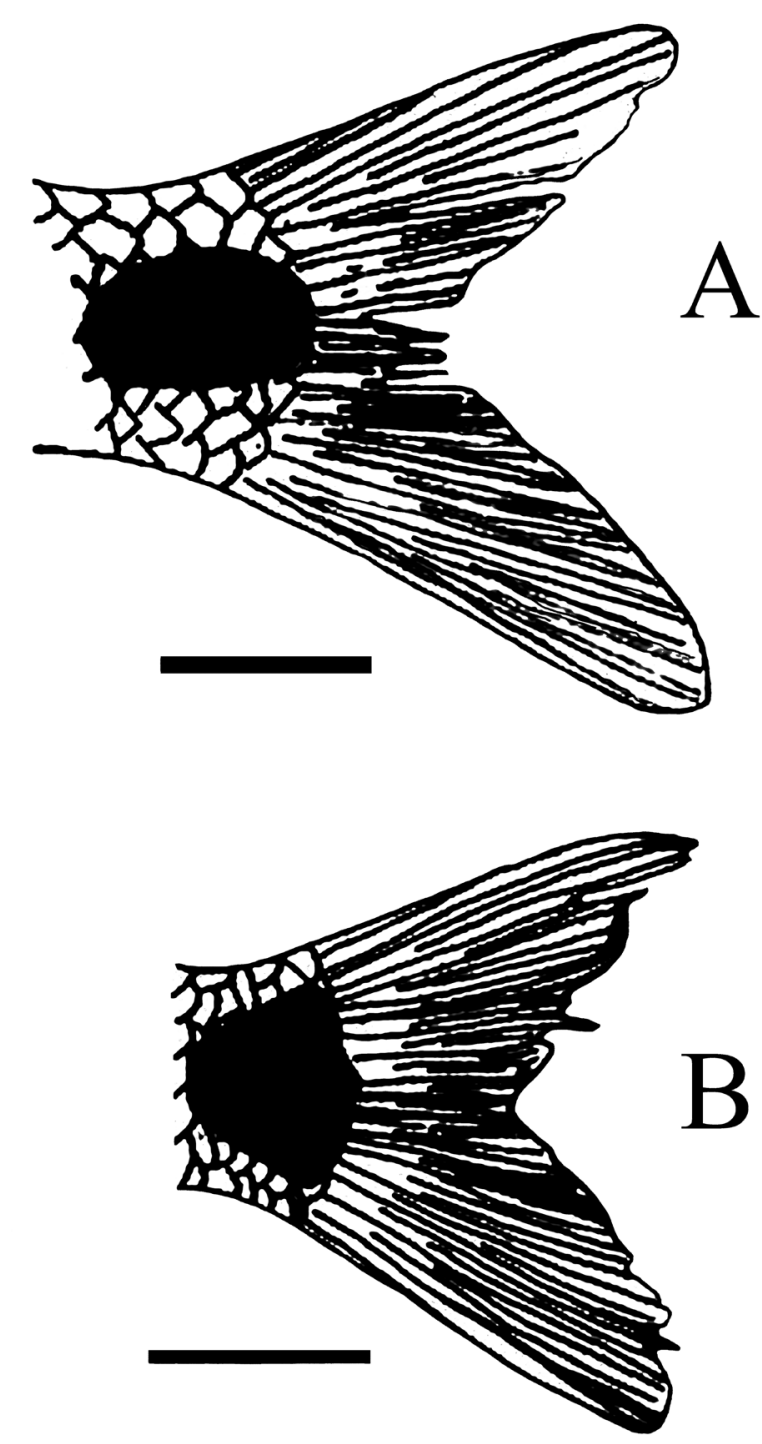

Fig. 3. Shape of caudal-peduncle spot in species of the Astyanax orthodus species-group. A. Astyanax orthodus Eigenmann, 1907. B. Astyanax embera sp. nov. Scale bar $=1 \mathrm{~cm}$. 


\section{Description}

Body compressed, greatest body depth at or anterior to dorsal-fin origin. Mouth terminal. Dorsal profile of head straight between snout tip to posterior margin of supraoccipital spine, convex between head and dorsal fin, convex between last dorsal-fin ray and adipose-fin origin. Caudal peduncle arched, with dorsal profile concave and ventral profile convex. Ventral profile convex between snout tip and posterior end of anal-fin base in males; in females convex to pelvic-fin insertions, concave beyond the insertion of pelvic fin to anal-fin origin.

Premaxillary teeth in two series; outer series with four tricuspid teeth covering three most medial teeth of internal series; inner row with five pentacuspid teeth. Maxilla long, of same width along entire length, with two tricuspid teeth set in anterior-most part of ventral margin. Dentary with anterior four teeth pentacuspid, following ten teeth smaller, progressively inclined posteromedially, varying from tri- to unicuspid; proportion of tri- vs unicuspid teeth quite variable.

Pored lateral-line scales 36(1), 37(11), 38(11), 39(13), 40(1), 41(1) $(\mathrm{n}=38)$; transverse scales from lateral line to dorsal-fin origin 7(13), $8(25)(\mathrm{n}=38)$; scales from lateral line to anal-fin origin $7(1), 8(29)$, $9(8)(n=38)$; scales from lateral line to pelvic-fin insertion 6(22), 7(15), 8(1) $(n=38)$. Predorsal midline covered with bilobed medial scales for more than three quarters of its length, naked anteriorly. Dorsalfin rays iii $9(n=38)$; first simple ray reduced in size, easily visible only in $C \& S$ specimens, detectable with dissecting needle in non-C\&S specimens; second simple ray about half length of third simple ray. Distal margin of dorsal fin slightly convex. Adipose-fin origin anterior to vertical through insertion of last anal-fin ray. Pectoral-fin rays i 10 i (2), i 11 i (23), i 12 i (12), i $13(1)(n=38)$. Anal-fin rays iii 25(7), iii 26(9), iii 27(12), iii 28(9), iii 29(1) $(\mathrm{n}=38)$; first simple rays only visible in C\&S material. Anal-fin origin posterior to vertical through insertion of last dorsal-fin ray (Table 1). Principal caudal-fin rays $10(8)$ associated with four dorsal hypurals, $9(8)$ associated with three ventral hypurals; dorsal procurrent rays $10-11(8)$; ventral procurrent rays $9-10(8)$.

Total vertebrae 34(8), including those of the Weberian apparatus: precaudal centra 16(2)-17(6), last two without true ribs; caudal centra 17(2)-18(6). Epipleurals 21(2)-22(6). Epineurals 30(2)-31(6); posterior-most epineural may reach anterior surface of urostyle. Hypurals 7(8); first dorsal hypural with anterior margin dotted, without projections without extensions that articulate the urostyle; second and third hypural with anterior margin swollen that contacting urostyle.

\section{Pigmentation in alcohol}

Sides of body yellowish, with reticulated pattern predominant over dorsal region of coelomic cavity. Silvery stripe present from humeral region to caudal-peduncle base, overlain by series of chevronshaped marks formed by dark lines along myosepta between myotomes extending from dorsal region of coelomic cavity to caudal peduncle; pigmented muscle septae forming chevrons not coinciding with scale rows. Chevrons without distal extensions both in juvenile and adult specimens.

Dorsal region of head and body chestnut brown. Sides of cranium and ventral surface of body light brown, not silvery. The pigments of the humeral region form an anterior and posterior humeral spot. The anterior spot is formed by two layers of pigment: brown melanophores distributed in thin superficial layer of the epithelium (Layer 1, Fig.1); deeper layer with dark melanophores (Layer 2, Fig. 1). Layer 2 forming polygon-shaped spot, with two parts, forming vertices on margins, usually with four sides, located from third to sixth or seventh scale of lateral series. Posterior humeral spot situated two or three scales posterior to anterior humeral spot, arc- or sigmoid-shaped, inconspicuous, covering two to three scales above lateral-line. Scales on sides of body with spots or dots. Caudal peduncle spot pentagonal, its posterior tip or margin centered on middle caudal-fin rays, usually not further prolonged on middle 
caudal-fin rays. Pectoral and pelvic fins mostly hyaline; pelvic fins with melanophores at tips of rays. Dorsal, caudal and anal fins with melanophores on interradial membranes.

\section{Sexual dimorphism}

Sexual dimorphism was observed in the ventral profile, which is convex from snout tip to posterior end of anal-fin base in males, but in females is convex from snout tip to the pelvic-fin insertions, then concave to the origin of the anal fin. No hooks were detected on fins of examined adult individuals.

\section{Distribution}

Middle portion of the Telembí River drainage, which is a tributary of the Patía River, Nariño Department, Pacific coast of Colombia (Fig. 4).

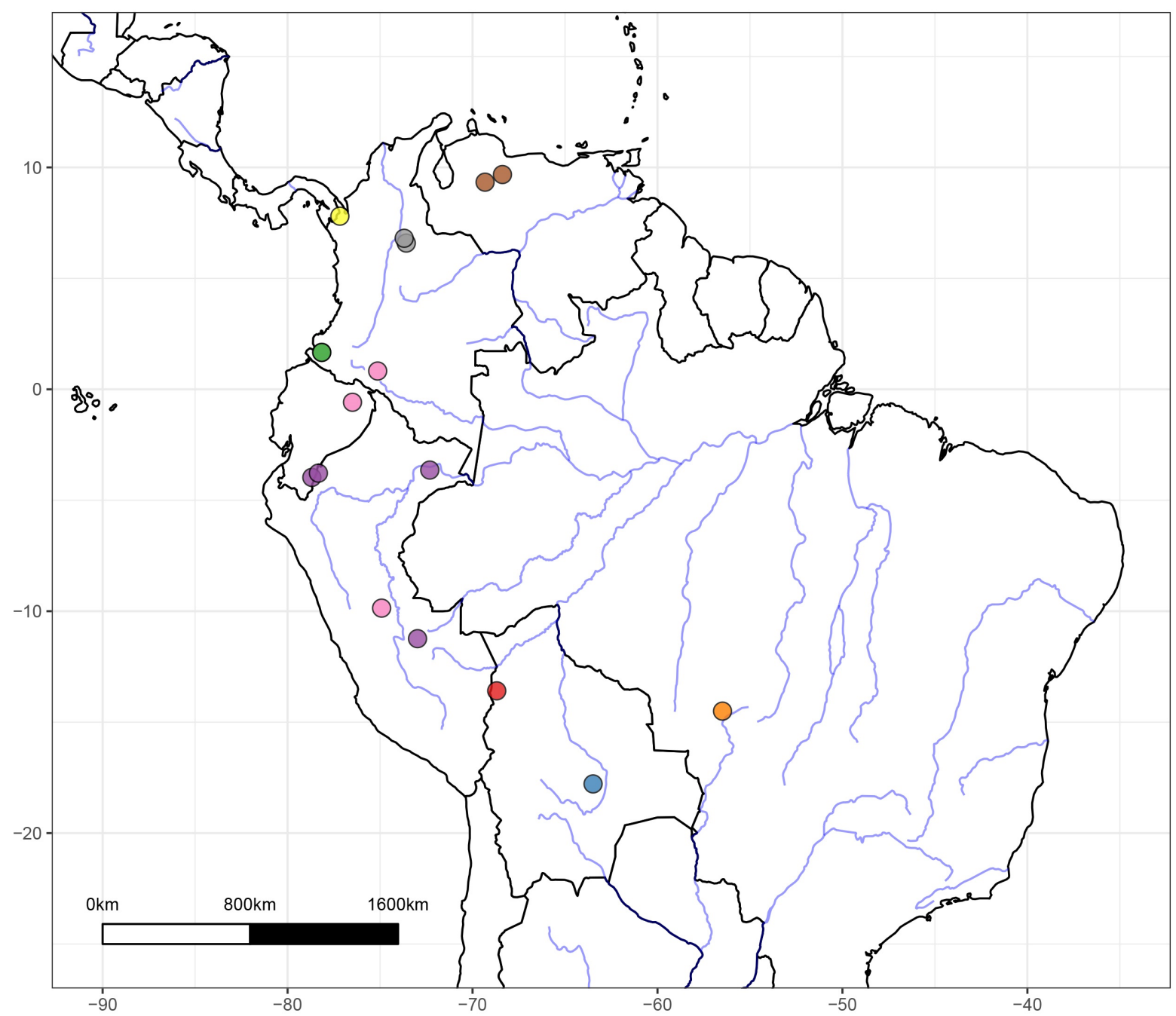

Fig. 4. Distribution of species of the Astyanax orthodus species-group (symbol includes type localities). 


\title{
Comments
}

The stream where the type locality of this species is located is subject to mining activity for gold, silver and platinum.

\author{
Astyanax boliviensis sp. nov. \\ urn:lsid:zoobank.org:act:A4DF0719-0A75-4401-9F8D-D52AA7FFDDF6
}

Figs 4-5, Table 1

\section{Diagnosis}

Astyanax boliviensis sp. nov. is a member of the orthodus species-group of Astyanax, differing from other species of the group in having lines extending from the tips of the chevrons on both the anterior and posterior extremes (proximal and distal sections of chevron extensions), forming extensions between the chevrons (vs chevrons without lines extending from their tips), except $A$. moorii comb. nov. which is distinguished by the number of lateral-line scales 39-42 (vs 44-50). It also differs from A. moorii comb. nov. in the upper jaw length $>34 \% \mathrm{HL}$ (vs $<47 \% \mathrm{HL}$ ). It further differs from $A$. villwocki by the absence of a dark stripe on the sides of the body (vs dark lateral stripe present or anterior prolongation of the caudal peduncle spot extending over the silvery lateral stripe). It further differs from A.orthodus, A. embera sp. nov. and A. yariguies in having a conspicuous rhomboidal caudal-peduncle spot with a short, anterior, prolongation that does not surpass a vertical through the anal-fin origin (vs spot on caudal peduncle a short polygon shape not surpassing the posterior tip of the anal fin in $A$. orthodus and $A$. embera sp. nov.; spot on caudal peduncle elongated as a stripe, continuing anteriorly to humeral region in $A$. villwocki). It differs from A. bopiensis nom. nov., in having fewer than four teeth extending over less than one third of the maxillary (vs more than five teeth extending over more than two thirds of the maxillary).

\section{Etymology}

The specific epithet boliviensis refers to Bolivia, the country where the type series was collected.

\section{Material examined}

\section{Holotype}

BOLIVIA: 87.9 mm SL, La Paz, Iturralde Province, Amazon River Basin, Madeira-Beni-Madidi-

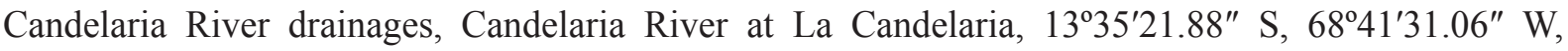
$304 \mathrm{~m}$ a.s.l. (CBF 13504).

\section{Paratypes}

BOLIVIA: Iturralde, La Candelaria, Ami National Park, Madidi River drainage: 5 specimens (sex unknown), 33.1-89.5 mm SL (CBF 7592); 8 specimens (sex unknown), 57.0-72.6 mm SL, 2 specimens (sex unknown) C\&S, 49.0-75.2 mm SL (CBF 7434); 12 specimens (sex unknown), 32.3-76.7 mm SL (CBF 7594); 4 specimens (sex unknown), 43.6-63.3 mm SL, 1 specimen (sex unknown) C\&S, $72.2 \mathrm{~mm}$ SL, Ixiamas (CBF 2828). - Isiboro, Mamoré River drainage: 8 specimens (sex unknown), 44.7-58.1 mm SL, de Villa River (UMSS 4692); 4 specimens (sex unknown), 49.4-86.0 mm SL, Rancho Cuatro Esquinas (UMSS 3750); 15 specimens (sex unknown), 54.7-79.0 mm SL, Colonia River San Carlos (UMSS 5282).

PERU: Puno, Sandia province: 2 specimens (sex unknown), 40.9-73.9 mm SL, 2 specimens (sex unknown) C\&S, $70.3 \mathrm{~mm}$ SL, Tavara River $2 \mathrm{~km}$ from the mouth of Quebrada Grande, Zona Reservada, Tambopata-Candamo (MUSM 3410). 


\section{Description}

Body compressed, greatest body depth at or anterior to origin of dorsal fin. Mouth terminal. Anterior half of dorsal profile of head slightly sigmoid, convex between verticals through snout tip and orbit, posterior half slightly concave between verticals through orbit and posterior margin of supraoccipital spine; profile between posterior margin of supraoccipital spine and origin of dorsal fin as between last ray of dorsal fin and origin of adipose fin convex. Dorsal and ventral margins of caudal peduncle arched, concave and convex, respectively. Ventral profile convex from tip of snout to insertion of pelvic fin, feature visible in both sexes.

Premaxillary teeth in two series; outer series with four tricuspid teeth covering three most medial teeth of inner series; inner tooth row with five pentacuspid teeth. Maxilla long, of same width along entire length, with three teeth in anterior-most part of ventral margin; anterior-most teeth pentacuspid; remaining two teeth tricuspid. Dentary with four anterior teeth pentacuspid, followed laterally by $8-11$ smaller teeth of increasing posterior inclination, reducing from tri- to unicuspid.

Pored scales of lateral line 39(2), 40(10), 42(3)(n=15), transverse scales from lateral line to dorsal-fin origin 7(1), 8(1) 10(13) $(n=15)$, scales from lateral line to anal-fin origin 7(2) 8(13) $(n=15)$, scales from lateral line to pelvic-fin insertion 6(3), 7(2), 8(10) $(\mathrm{n}=15)$. Predorsal midline covered with bilobed medial scales for more than $3 / 4$ of its length, naked anteriorly.

Dorsal-fin rays iii $9(\mathrm{n}=15)$; first simple ray small, only visible in cleared and stained specimens; second simple ray about half length of third simple ray. Distal margin of dorsal fin slightly convex. Adipose-fin origin anterior to vertical through insertion of last anal-fin ray. Pectoral-fin rays i 10(10), i 11(1), i 14 (4). Pelvic-fin rays i 6-7 i. Anal-fin rays iii 23-30, first simple rays only visible in cleared and stained material. Anal-fin origin posterior to vertical through insertion of last dorsal-fin ray (Table 1).

Caudal-fin rays 10-10; dorsal lobe with 12(4), 14(1) procurrent rays, ventral with 10(5) procurrent rays. Upper 10(5) principal caudal-fin rays associated with four dorsal hypurals, next 9(5) associated with three ventral hypurals and last principal ray associated with last hemal spine. Total vertebrae 35(5), including those of Weberian apparatus: precaudal centra 16(3) and 17(2), last three without true pleural rib. Caudal centra 18(3), 19(2). Epineurals 36(1), 38(2), 40(1), 41(1) posterior-most epineural may not

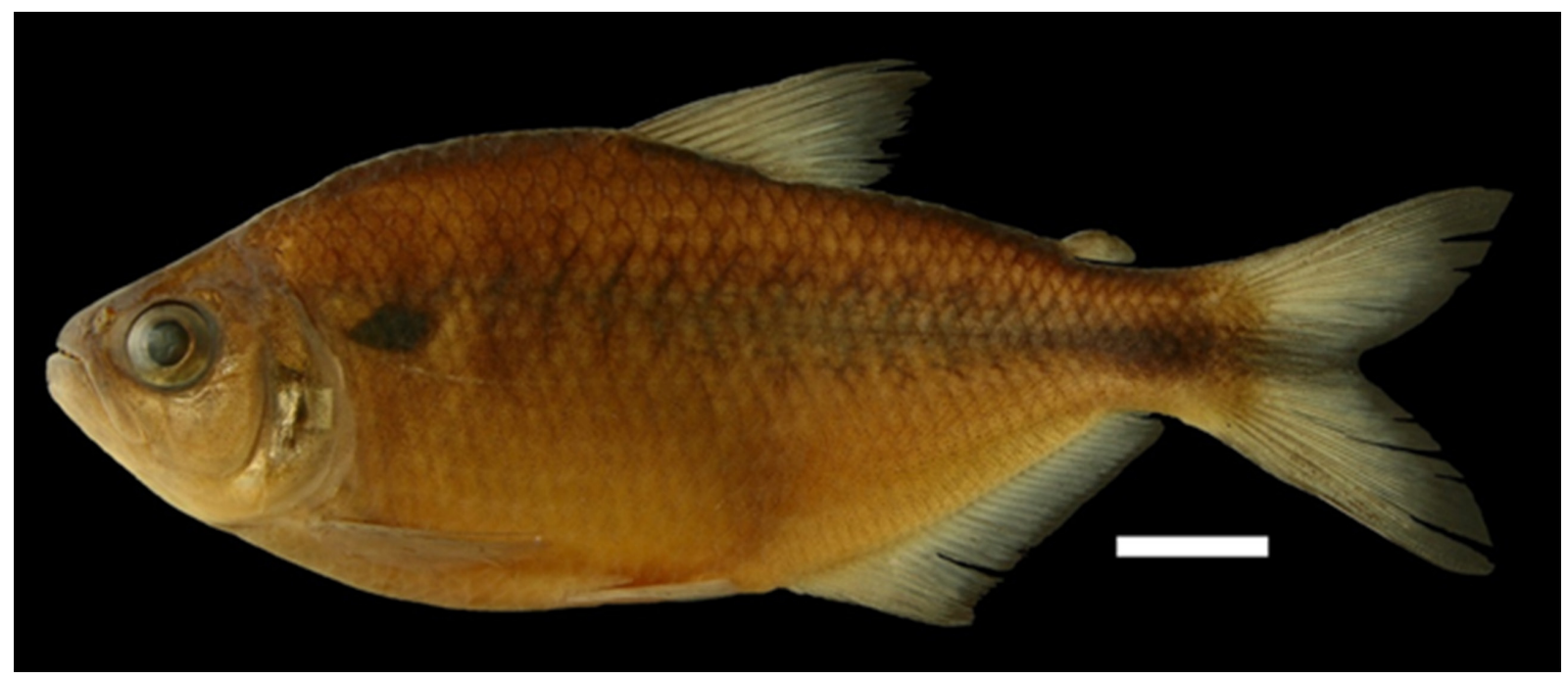

Fig. 5. Astyanax boliviensis sp. nov., paratype, $79.0 \mathrm{~mm}$ SL, Colonia San Carlos River, Isiboro, Mamoré, Bolivia (UMSS 5282). Scale bar $=1 \mathrm{~cm}$. 


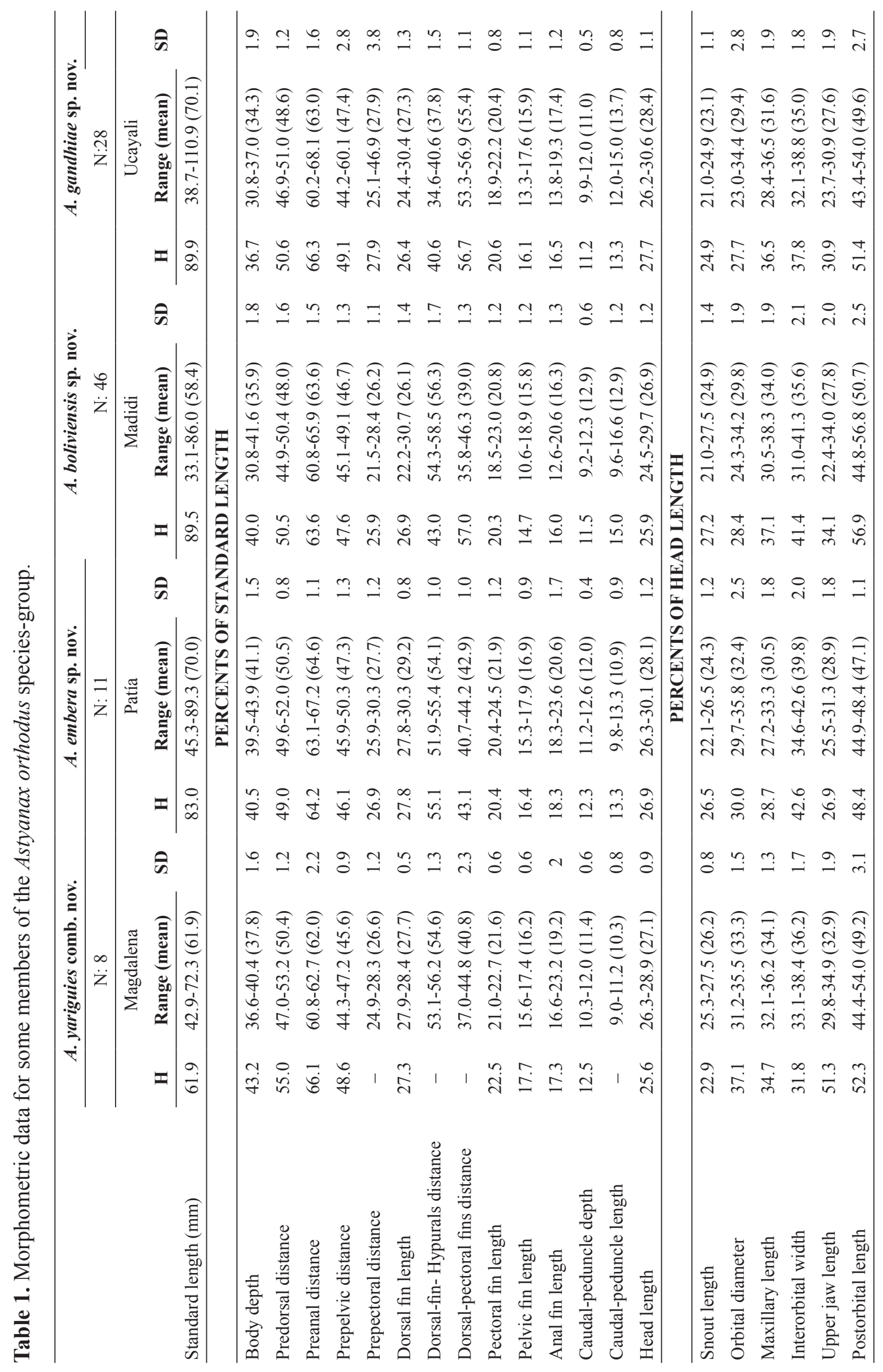


reach anterior surface of urostyle; epipleurals 20(5). Caudal skeleton with seven hypurals. First three hypurals with swollen anterior margins in contact with urostyle.

\title{
Pigmentation in alcohol
}

Sides of body yellowish, without reticulated pattern, with silver midlateral stripe present from humeral region to caudal-peduncle base, overlain by series of chevron-shaped marks formed by dark lines along myosepta between myotomes extending from dorsal region of coelomic cavity to caudal peduncle; pigmented muscle septae forming chevrons not coinciding with scale rows. Chevrons with distal extensions both in juvenile and adult specimens.

Dorsal region of head and body chestnut brown. Sides of cranium and ventral surface of body light brown, not silvery. Melanophores of humeral region forming two (anterior and posterior) humeral spots. The anterior spot is formed by two layers of pigment, with brown melanophores distributed in thin superficial layer of the epithelium (Layer 1, Fig. 1); deeper layer that with dark melanophores (Layer 2, Fig. 1). Layer 2 forming polygon-shaped spot, with two parts, forming vertices on margins, usually forming four-sided spot located from second to fifth or sixth scale of lateral series. Posterior humeral spot situated two scales posterior to anterior humeral spot, arc- or sigmoid-shaped, inconspicuous and covers two to three scales above lateral-line. Individual scales on sides of body with spots or dots. Caudal peduncle spot rhomboid with short anterior extension over silver lateral stripe not surpassing anal-fin origin, dark pigment of caudal peduncle stripe continued on to middle caudal-fin rays with dark pigment present on tips of remaining rays. Pectoral, pelvic, dorsal and anal fins hyaline.

\section{Sexual dimorphism}

No sexual dimorphism was observed, no hooks found on fins.

\section{Distribution}

Known from the drainages of the Madidi and Mamoré Rivers, tributaries of the Madeira River, Upper Amazon River Basin of Bolivia and Peru (Fig. 4).

\author{
Astyanax gandhiae sp. nov. \\ urn:lsid:zoobank.org:act:DB1A95AA-8E70-40F4-B739-043872A32906
}

Figs 4, 6, Table 1

\section{Diagnosis}

Astyanax gandhiae sp. nov. is a member of the orthodus species-group of Astyanax differing from others members of the group (A. orthodus, A.villwocki, A. superbus, A. bopiensis nom. nov., A. boliviensis sp. nov., A. yariguies comb. nov. and $A$. embera sp. nov.) in lacking a spot on the caudal peduncle. It can be further distinguished from $A$. villwocki by having a short lateral stripe extending from the caudal spot, that does not extend anteriorly beyond a vertical through the origin of the anal fin (vs lateral stripe extending anteriorly beyond a vertical through anterior origin of the anal fin). It differs from A. bopiensis nom. nov. in having fewer teeth that do not cover more than a third of the length of the maxillary (vs a larger number of teeth covering more than two thirds of the maxillary). It differs from A. moorii comb. nov. for dorsal-fin-hypural distance less than $45 \%$ SL(vs more than 50 ), by dorsalpectoral distance greater than $50 \%$ SL (vs less than 50), interorbital distance greater than $32 \%$ HL (vs less 32 ) and by upper jaw length than less $35 \% \mathrm{HL}$ (vs greater than 40 ).

\section{Etymology}

This species epithet is named in homage to the late Mrs Maria Gandhi Calderon, mother of the first author, and used as a noun in apposition. 


\section{Material examined}

\section{Holotype}

PERU: 89.4 mm SL, Department of Amazonas, Condorcanqui Province, Marañon River Basin, upper Cenepa River drainage, $3^{\circ} 58^{\prime} 15^{\prime \prime}$ S, 7841'15" W (MUSM 46845).

\section{Paratypes}

PERU: Department of Amazonas, Amazon River Basin, Condorcanqui, upper Cenepa River drainage: 14 specimens (sex unknown), 62.1-109.6 mm SL, Quebrada Capitán (MUSM 20891, MUSM 21278); 2 specimens (sex unknown), 56.1-68.7 mm SL, Capitán Quebrada (MUSM 21278); 2 specimens (sex unknown), 85.9-97.1 mm SL, Quebrada Capitán Ponce, $750 \mathrm{~m}$ a.s.l. (MUSM 21287); 1 specimen (sex unknown), $85.7 \mathrm{~mm} \mathrm{SL}$, collected with holotype (MUSM 21300); 1 specimen (sex unknown), $65.4 \mathrm{~mm}$ SL, Capitan Ponce Bravo Quebrada, 346'41.40" S, 78 20'4.61" W (MUSM 21312); 1 specimen

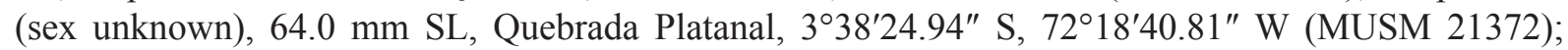
11 specimens (sex unknown), 38.7-49.3 mm SL, Ucayali department, Atalaya province, Sepahua, Lazaro

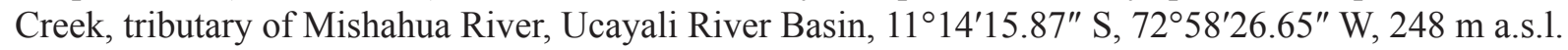
(MUSM 35474); 1 specimen (sex unknown), $44.5 \mathrm{~mm}$ SL, Huacamayo River, km. 155 on road from Pucallpa to Tingo-Maria, Padre Abad province, Ucayali River Basin (MUSM 2392); 1 specimen (sex unknown), $93.9 \mathrm{~mm}$ SL, 2 specimens (sex unknown) C\&S, 59.0-61.2 mm SL, Víbora Creek, tributary of Pisqui River, Loreto, upper Amazon (MUSM 46846); 3 specimens (sex unknown), 50.0-98.6 mm SL, Tavara River $2 \mathrm{~km}$ from mouth of Quebrada Grande, Puno, Sandia, Zona Reservada TambopataCandamo (MUSM 46847).

\section{Description}

Body compressed, greatest body depth at or anterior to dorsal-fin origin. Mouth terminal. Dorsal profile of head straight between snout tip and posterior margin of supraoccipital spine, convex between head and dorsal fin, convex between head and at base of dorsal fin, convex between last dorsal-fin ray to adipose-fin origin. Dorsal and ventral caudal-peduncle margins straight. Ventral profile convex between tip of snout and pelvic-fin insertion.

Premaxillary teeth in two series; outer series with four tricuspid teeth covering three medial most teeth of inner series; inner row with five pentacuspid teeth. Maxilla long, of same width along entire length, with 3-6 tricuspid teeth set in anterior-most part of ventral margin. Dentary with anterior four teeth pentacuspid, followed laterally by $8-9$ smaller teeth that progressively increase in postero-medial inclination, decreasing from tri- to unicuspid; number of lateral teeth highly variable.

Pored scales of lateral line 40(15), 41(3), 42(1) $(\mathrm{n}=18)$, scales from lateral line to origin of dorsal fin $8(18)(n=18)$, scales from lateral line to origin of anal fin $7(10), 8(8)(n=18)$, scales from lateral line to insertion of pelvic fin 6(11), 7(7) $(n=18)$. Rays of dorsal fin iii 9, first simple ray small, only visible in cleared and stained specimens, second simple ray about half length of third simple ray. Distal margin of dorsal fin slightly convex. Origin of adipose fin anterior to vertical through insertion of last ray of anal fin. Rays of pectoral fin i 10 ii (11), i 12 ii (7). Rays of pelvic fin i 7(18). Rays of anal fin iii-iv 25-27; first simple rays only visible in cleared and stained material. Origin of anal fin posterior to vertical through insertion of last ray of dorsal fin (Table 1).

Caudal fin with 10-9 principal rays; dorsal lobe supporting 12(4), procurrent rays; ventral lobe, 10(4) procurrent rays. Upper 10(4) principal caudal-fin rays associated with four dorsal hypurals, next 9(4) associated with three ventral hypurals.

Total vertebrae 37(4), including those of Weberian apparatus: precaudal centra 17(2) and 18(2), last two without true pleural rib. Caudal centra 19(2), 20 (2). Epineurals 34(2); posterior-most epineural 
occasionally not reaching anterior surface of urostyle; epipleurals 21(2). Caudal skeleton with seven hypurals. First dorsal three hypurals with swollen anterior margin in contact with urostyle.

\section{Pigmentation in alcohol}

Sides of body yellowish, without reticulated pattern over dorsal region of coelomic cavity, silvery stripe extending from humeral region to base of caudal peduncle, overlain by series of chevron-shaped marks formed by dark lines along myosepta between myotomes extending from dorsal region of coelomic cavity to caudal peduncle; pigmented muscle septae forming chevrons not coinciding with scale rows. Chevrons lacking distal extensions both in juvenile and adult specimens.

Dorsal region of head and body chestnut brown. Sides of cranium and ventral surface of body light brown, not silvery. Melanophores of humeral region forming two (anterior and posterior) humeral spots. The anterior spot formed by two layers of pigment, with brown melanophores distributed in thin superficial layer of epithelium (Layer 1, Fig. 1) and another deeper layer consisting of dark melanophores (Layer 2, Fig. 1). Layer 2 forming polygon-shaped spot made up of two different layers of melanophores that do not precisely overlap, forming vertices on lateral margins, usually resulting in four-sided spot located between third and sixth or seventh scale of lateral series. Posterior humeral spot situated two or three scales posterior to the anterior humeral spot, arc- or sigmoid-shaped, inconspicuous, covering two to three scales above lateral-line. Individual scales on sides of body lacking spots or dots. Spot on caudal peduncle absent. Lateral stripe formed by dispersed brown pigment present only on posterior portion of body, located above posterior two-thirds of anal-fin base and extending on to caudal peduncle. Pectoral, pelvic, dorsal and anal fins hyaline; pigment present on interradial membranes of middle caudal-fin rays.

\section{Sexual dimorphism}

No sexual dimorphism observed, no hooks found on fins.

\section{Distribution}

Astyanax gandhiae sp. nov. is known from the Ucayali and Madre de Dios River drainages, Cenepa River, tributary from Marañón River, Upper Amazon Basin, Peru (Fig. 4).

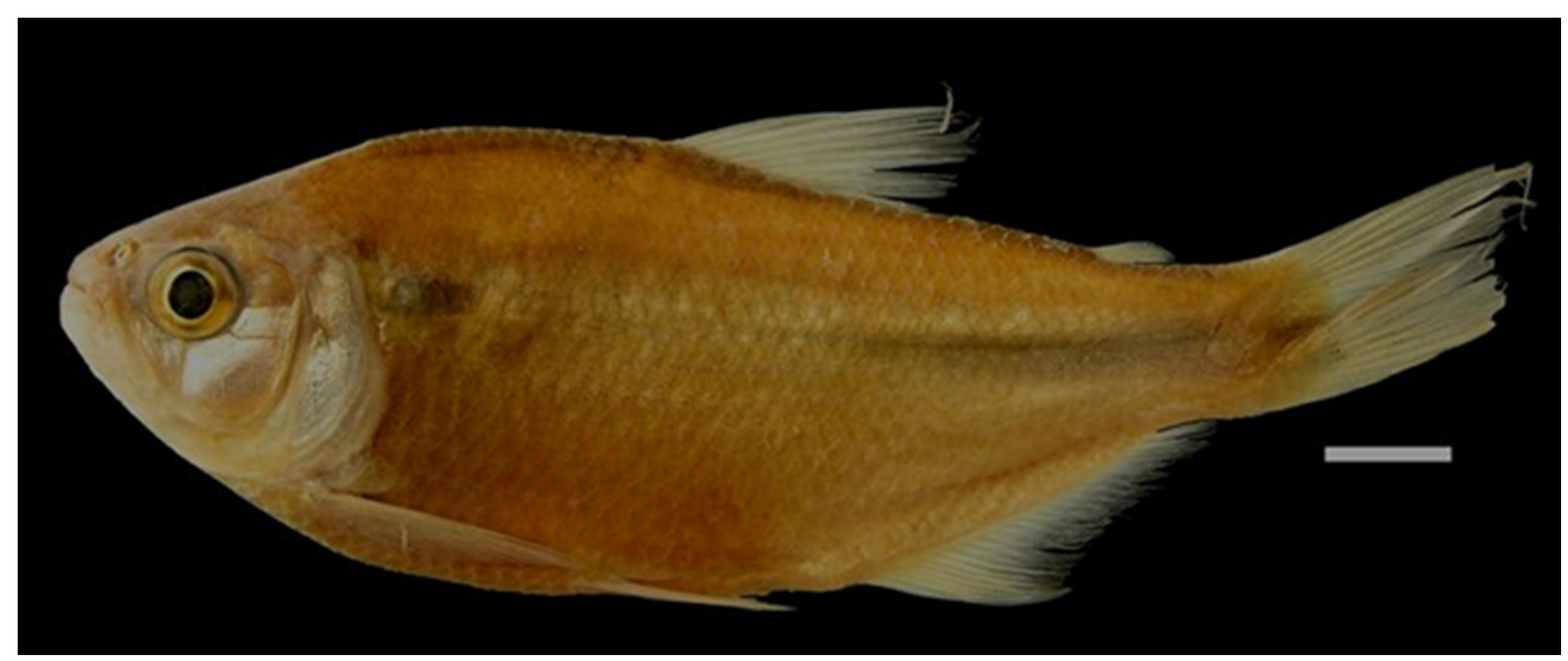

Fig. 6. Astyanax gandhiae sp. nov., holotype, $89.4 \mathrm{~mm}$ SL, Condorcanqui, Amazonas, Upper Cenepa River drainage (MUSM 46845). Scale bar $=1 \mathrm{~cm}$. 
Astyanax bopiensis nom. nov.

Figs 4, 7, Table 2

Astyanacinus multidens Pearson, 1924: 41, pl. 9 fig. 4. Original description, type locality: Bolivia, Colorado River, lower Bopi River.

\section{Diagnosis}

Astyanax bopiensis nom. nov. is a member of the orthodus species-group, differing from other species of the group in having a reticulated pattern on the sides of the body formed by dark pigment on the medio-distal margins of scales (vs reticulated pattern absent); and in having 7 to 13 teeth on the maxilla covering at least half the length of its ventral margin (vs 0-6 teeth); there are four scales touching the base of the pectoral fin along its ventral margin (vs three scales along ventral margin of pectoral-fin base; Fig. 9); number of neural spines from the fourth vertebra to the first pterygiophore of the dorsal fin 7 to 11 (vs 5 to 6). It differs from A. moorii comb. nov. in having the dorsal-fin-hypural distance less than $45 \%$ SL (vs more $50 \%$ SL), by body depth less $34 \%$ SL (vs more $34 \%$ SL), by dorsal-fin length less $28 \%$ SL (vs more $28 \%$ SL), by dorsal pectoral-fin distance more than $50 \%$ SL (vs less than $50 \%$ SL), by pectoral-fin length less $21.5 \%$ SL (vs more than $21.5 \%$ SL), by pelvic-fin length less $16 \%$ SL (vs more than $16 \% \mathrm{SL}$ ), by maxilla length more than $46.5 \% \mathrm{HL}$ (vs less than $40 \% \mathrm{HL}$ ) and by upper jaw length less $45 \%$ HL (vs more than $45 \% \mathrm{HL}$ ).

\section{Etymology}

The specific epithet bopiensis refers to the river where the original type material was collected. It is used as a noun in apposition.

\section{Material examined}

\section{Lectotype}

BOLIVIA: (sex unknown), 96.9 mm SL, Colorado River, Lower Bopi (CAS 39955).

\section{Paralectotypes}

BOLIVIA: (sex unknown) 79.8-122.9 mm SL, Río Colorado, Lower Bopi (CAS 236977)

\section{Non type material}

PERU: 1 specimen (sex unknown), Puno, Sandia (MUSM 3410); Madre de Dios (MUSM 3418, MUSM 3758); 1 specimen (sex unknown), $143.9 \mathrm{~mm}$ SL (CAS 38955); 2 specimens (sex unknown), 49.4$50.5 \mathrm{~mm}$ SL, 1 specimen (sex unknown) C\&S, Puno, Sandia Tavara River, Zona Reservada TambopataCandamo (MUSM 3410); 5 specimens (sex unknown), 38.9-57.3 mm SL, 2 specimens (sex unknown) C\&S, Culli Creek, Alto Madre de Dios River, Madre de Dios River Basin, Manu, Madre de Dios (MUSM 3814); 1 specimen (sex unknown), 143.9 mm SL, Madre de Dios, Manu, Culli stream, Madre de Dios River, Upper Amazon River (MUSM 3758).

\section{Description}

Body compressed, greatest body depth at or anterior to dorsal-fin origin. Mouth terminal. Dorsal profile of head straight between snout tip and posterior margin of supraoccipital spine, convex between head and dorsal fin. Convex between head and at base of dorsal fin, convex from last dorsal-fin ray to adiposefin origin. Dorsal and ventral caudal peduncle margins straight. Ventral profile convex from tip of snout to pelvic-fin insertion.

Premaxillary teeth in two series; outer series with four tricuspid teeth covering three medial-most teeth of inner series. Inner row with five pentacuspid teeth. Maxilla long, of same width along entire length, with 7-13 teeth on anterior-most part of ventral margin; anterior-most teeth tricuspid then with less 
well-defined cusps, 4 or 5 posterior teeth conical. Dentary with anterior four pentacuspid teeth, followed laterally by 11-13 smaller teeth of increasing posterior inclination, decreasing from tri- to unicuspid. Pored scales of lateral line 39(4), 40(4) or 41(2), scales from lateral line to dorsal-fin origin 7(4) to 8(6) $(\mathrm{n}=10)$, scales from lateral line to anal-fin origin 7(8) to $8(2)(\mathrm{n}=10)$, scales from lateral line to pelvicfin insertion 5(3) to 6(7) $(\mathrm{n}=10)$, predorsal midline with complete series of scales along dorsal midline.

Dorsal-fin rays iii $9(\mathrm{n}=10)$; first simple ray small, only visible in cleared and stained specimens; second simple ray about half length of third simple ray. Distal margin of dorsal fin slightly convex. Adipose-fin origin anterior to vertical through insertion of last anal-fin ray. Pectoral-fin rays i 11-12 i. Pelvic-fin rays i 7 i. Anal-fin rays iii-v, 22(2), 23(5), 24(1), 25(1) $(n=10)$, first simple rays only visible in cleared and stained material. Anal-fin origin posterior to vertical through insertion of last dorsal-fin ray.

Total vertebrae 36-38(3), including those of the Weberian apparatus: precaudal centra 18(2), 19(1), last three without true pleural rib. Caudal centra 18(1), 19(2). Epineurals 33(2), 35(1), posterior-most epineural occasionally not reach anterior surface of urostyle; epipleurals 21(1), 22 (2). Caudal fin with seven hypurals; dorsal and ventral lobes approximately equal in length and width; second hypural thickened anteriorly; 11(1), 12(2) dorsal procurrent rays; 10(3) principal rays in dorsal lobe, 10(2), 11(1) ventral procurrent rays, 9(3) principal rays in ventral lobe.

\section{Pigmentation in alcohol}

Sides of body yellowish, with reticulated pattern over upper region of coelomic cavity, silver stripe extending from humeral region to caudal-peduncle base; overlain by series of chevron-shaped marks formed by dark lines along myosepta between myotomes extending from dorsal region of coelomic cavity to caudal peduncle; pigmented muscle septae forming chevrons not coinciding with scale rows.

Dorsal region of head and body chestnut brown. Sides of cranium and ventral surface of body light brown, not silvery. Melanophores of humeral region forming two spots (anterior and posterior humeral spots). Anterior spot formed by two layers of pigment: brown melanophores (Layer 1, Fig.1) distributed in thin superficial layer of epithelium, another deeper layer consisting of dark melanophores (Layer 2, Fig. 1). Layer 2 forming polygon-shaped anterior humeral spot, divided in two groups of melanophores that do not precisely overlap, forming four-sided spot extending from the third to fourth or fifth scale of lateral series. Posterior humeral spot situated two or three scales posterior to anterior humeral spot, arc- or sigmoid-shaped, inconspicuous, covering two to three scales above lateral-line. Scales on sides of body with spots or dots.

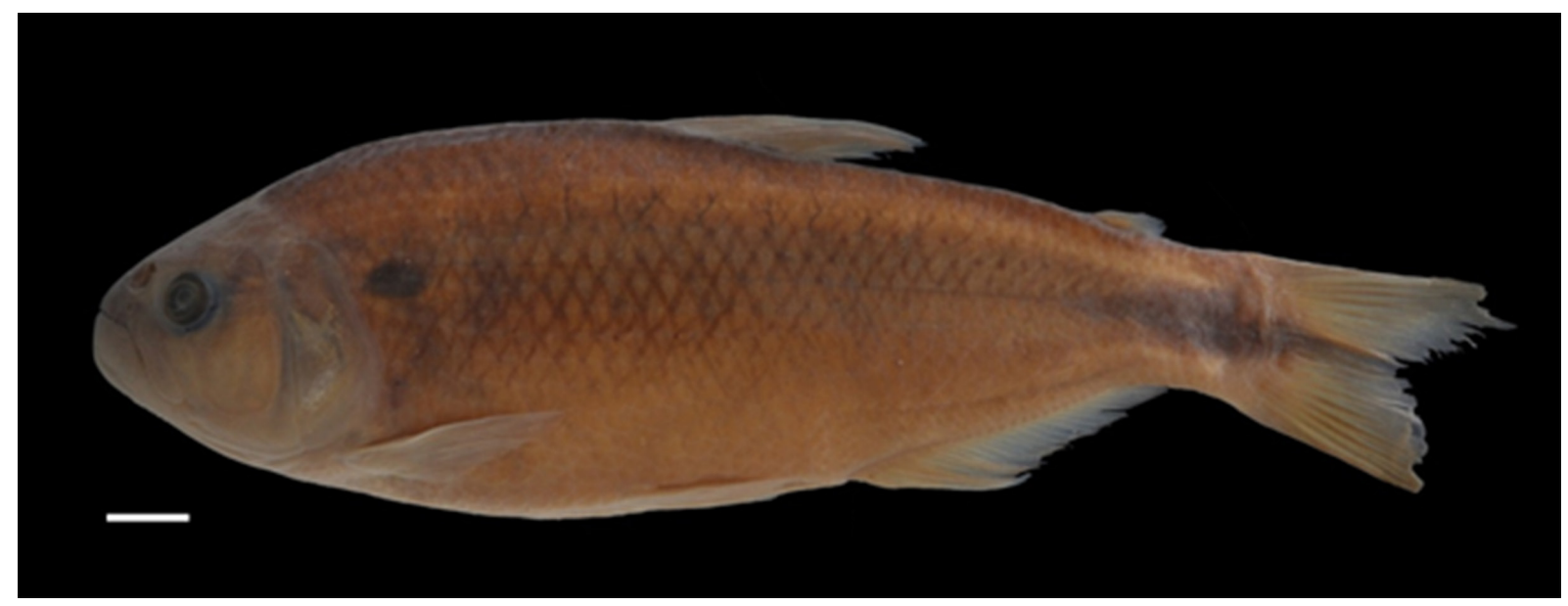

Fig. 7. Astyanax bopiensis nom. nov., $143.9 \mathrm{~mm}$ SL, Quebrada Culli, Madre de Dios River drainage, Upper Amazon, Peru (MUSM 3758). Scale bar $=1 \mathrm{~cm}$. 


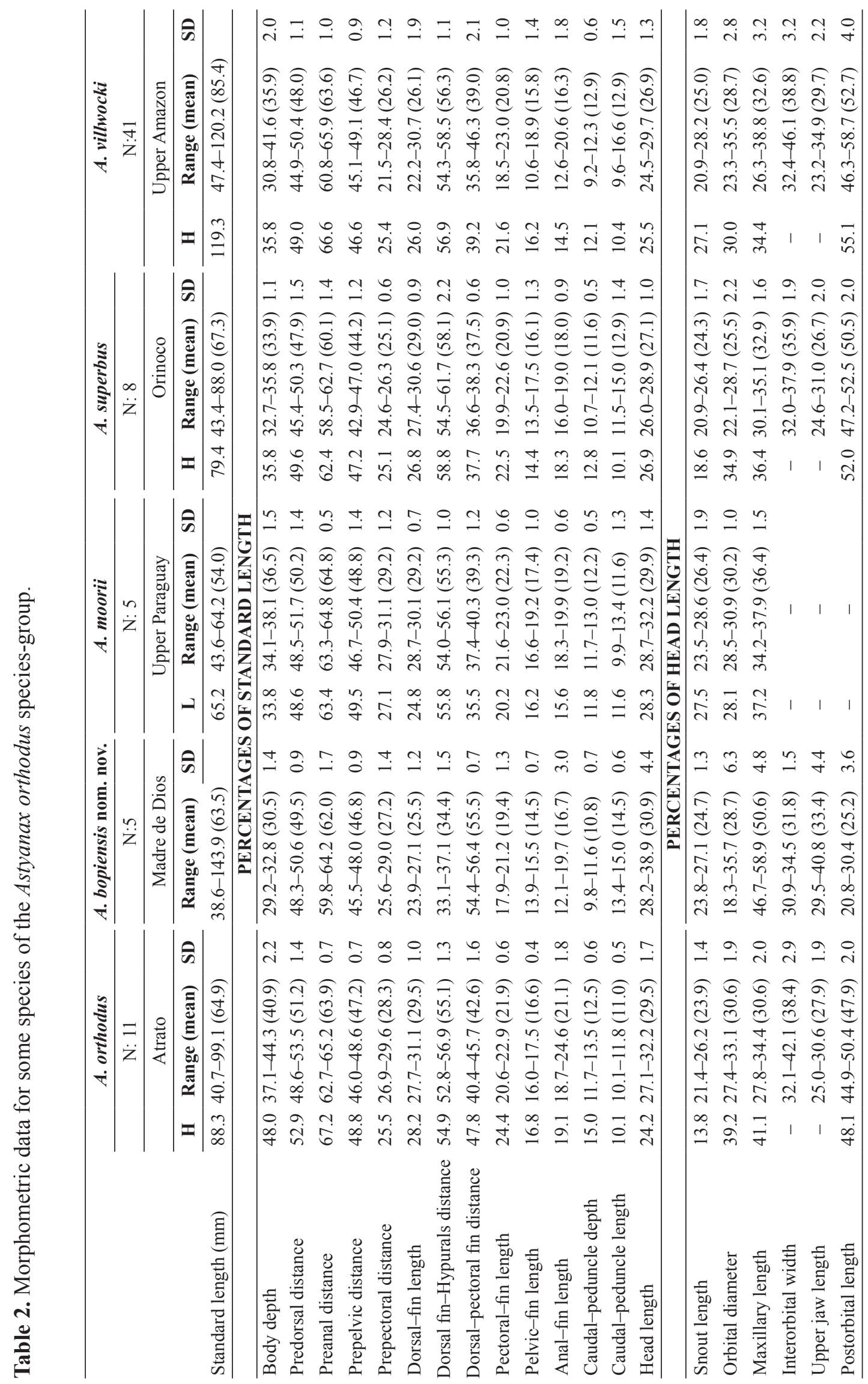


Caudal peduncle spot rhomboid with short anterior extension (over silver lateral stripe) that does not extend anterior beyond vertical through anal-fin origin; dark pigment of caudal peduncle stripe continued onto middle caudal-fin rays with dark pigment present on tips of remaining rays. Pectoral, pelvic, dorsal and anal fins hyaline.

\section{Sexual dimorphism}

No sexual dimorphism observed.

\section{Taxonomic comments}

Our assignment of Astyanacinus multidens Pearson, 1924 to the genus Astyanax relegates it to the status of a junior secondary homonym of Astyanax multidens Eigenmann, 1908. We propose the replacement name, Astyanax bopiensis nom. nov., following rules established in Article 59 of the International Code of Zoological Nomenclature (International Commission on Zoological Nomenclature 1999).

\section{Distribution}

Known from the drainages of the Madidi and Mamoré Rivers, Colorado River, lower Bopi River, tributaries of the Madeira River, upper Amazon Basin of Bolivia and Peru (Puno and Madre de Dios) (Fig. 4).

Astyanax orthodus Eigenmann in Eigenmann \& Ogle, 1907

Figs $3 \mathrm{~A}, 4,8$, Table 2

Astyanax orthodus Eigenmann in Eigenmann \& Ogle, 1907: 27, fig. 23. Original description, type locality: Truando, Rio Atrato River Basin, Chocó, Colombia.

\section{Diagnosis}

Astyanax orthodus is a member of the orthodus species-group (as defined above) differing from A. villwocki, A. superbus, A. bopiensis nom. nov., A. gandhiae sp. nov. and A. yariguies by having a conspicuous, polygonal spot on the caudal peduncle that does not extend anteriorly to vertical line through posterior tip of anal fin (vs spot extending anteriorly as a stripe beyond vertical line through posterior tip of anal fin). It further differs from A. superbus by the absence of brown marks along the sides of body (vs presence of a series of longitudinal brown marks along the sides of body). It differs from $A$. boliviensis sp. nov. in having shorter, simple extension of the chevrons (vs chevron extension elongate and branched distally). It differs from $A$. gandhiae sp. nov. in having a reticulated pattern predominant over upper region of coelomic cavity (vs without reticulated pattern predominant over upper region of coelomic cavity). It differs from A. embera sp. nov. in the position, size and shape of the spot on the caudal peduncle, which does not extend to the dorsal and ventral margins of the caudal peduncle (vs caudal peduncle extending as a fan-shaped blotch that reaches, or almost reaches, the dorsal and ventral margins of the caudal peduncle, Fig. 3A). The new species is distinct from A. moorii comb. nov. in having the distance between the dorsal and pectoral fins more than $40.4 \%$ HL (vs less than $40.3 \% \mathrm{HL}$ ), interorbital distance more than $32 \% \mathrm{HL}$ (vs less $32 \% \mathrm{HL}$ ) and upper jaw length less than $31 \%$ HL (vs more than $45 \% \mathrm{HL}$ ).

\section{Etymology}

The specific epithet orthodus is latinized from Greek 'orthodon', meaning 'straight tooth', in reference to the straight posterior surface of the inner premaxillary teeth and the cusps, which Eigenmann (in Eigenmann \& Ogle 1907) used to distinguish A. orthodus from A. bimaculatus. 


\section{Material examined}

Holotype (examined from photograph)

COLOMBIA: $88.3 \mathrm{~mm}$ SL, NW Colombia, Department of Chocó, Rio Sucio Municipality, Urabá, Truandó River, lower Atrato River Basin, Caribbean coast (USNM 55655).

\section{Other material}

COLOMBIA: Chocó: 2 q, 66.1-71.6 mm SL, Atrato River Basin, Truandó River, tributary Atrato River (AMNH 5370); 2 +, $86.9 \mathrm{~mm}$ SL, Yuto, Atrato River Basin, Yuto River, tributary Atrato River (IAvHP 6494); 16 우, 32.3-100.7 mm SL, 2 đิ ฮิ, 2 우, C\&S, 51.4-67.8 mm SL, Rio Sucio municipality, vereda Sautatá, Atrato River Basin,Tendal Creek (IAvHP 7146); 11 우, 37.4-51.9 mm SL, Atrato River Basin, Rio Sucio Municipality, Sautata Strema ("vereda"), Tendal Creek ("quebrada"), Parque Natural Nacional Los Katios, $07^{\circ} 48^{\prime} 08^{\prime \prime}$ N, $77^{\circ} 10^{\prime} 22^{\prime \prime}$ W, $161 \mathrm{~m}$ a.s.1. (IAvHP 7208); 8 q + , 32.6-76.1 mm SL, 2 우 우 C\&S, 56.8-61.3 mm SL, rio Sucio Municipality, Sautata Stream ("vereda"), Atrato River Basin, Tendal Creek, Parque Natural Nacional Los Katios (IAvHP 7209); 2 우, 82,6-99.4 mm SL, Sucio River, Sautata Stream ("vereda"), Atrato River Basin,Tendal Creek, Parque Natural Nacional Los Katios (IAvHP 7210); 1 § , 71.5 mm SL, Acandí, Atrato River Basin, tributary of Nati River (IUQ 1319).

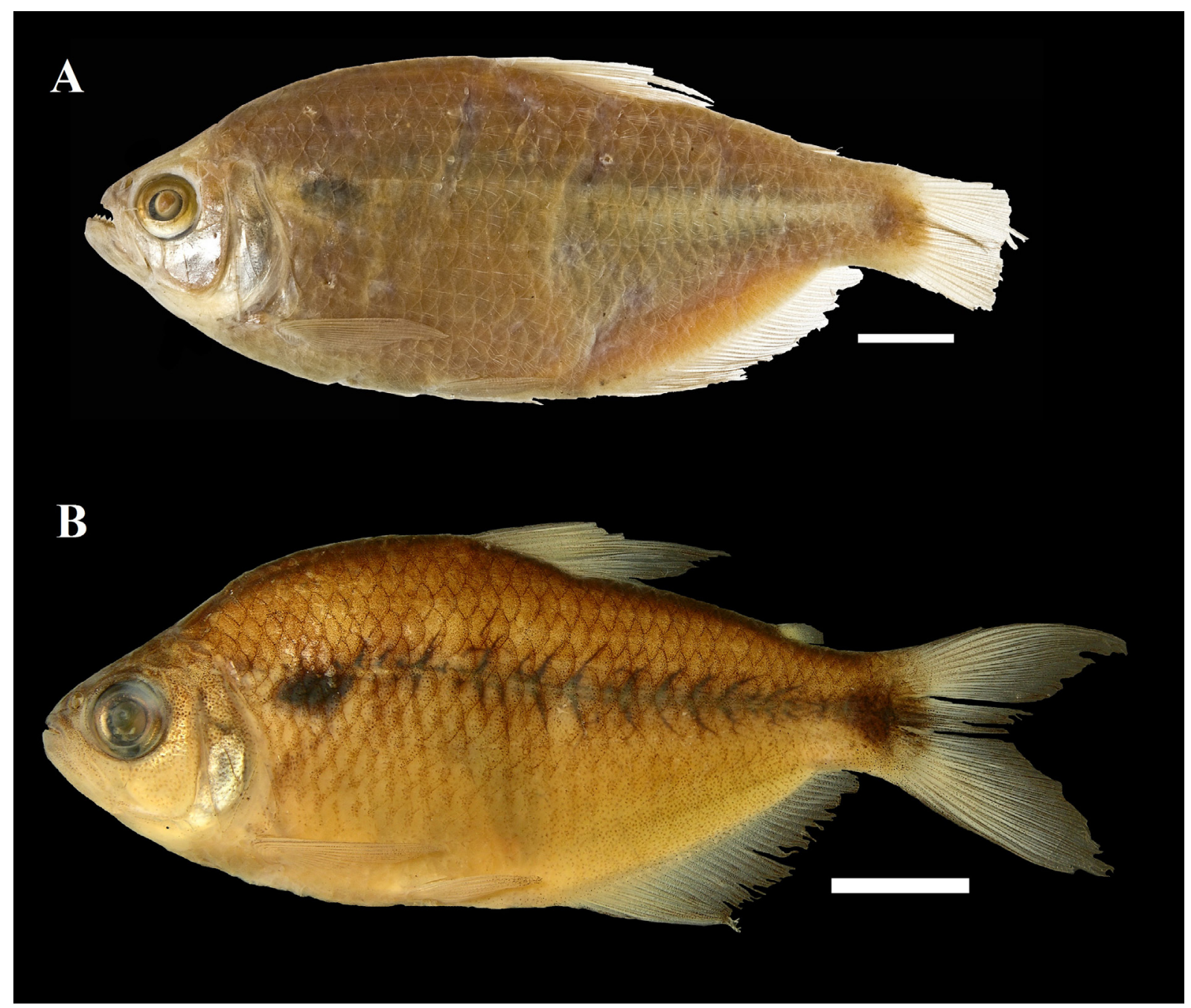

Fig. 8. Astyanax orthodus Eigenmann, 1907. A. Holotype, $88.3 \mathrm{~mm} \mathrm{SL}$, Truando River, Atrato River Basin, Chocó, Pacific coast of Colombia (USNM 55655). B. $32.5 \mathrm{~mm}$ SL, Vereda Sautatá, Atrato River drainage, Chocó, Pacific coast of Colombia (IAVH 7146). Scale bars $=1 \mathrm{~cm}$. 


\section{Description}

Body compressed, greatest body depth at or anterior to dorsal-fin origin. Mouth terminal. Dorsal anterior profile of head sigmoid, concave between snout tip and posterior margin of supraoccipital crest, convex between supraoccipital and dorsal fin, convex between last dorsal-fin ray and adipose-fin origin. Dorsal and ventral caudal peduncle margins straight. Ventral profile convex from tip of snout to pelvic-fin insertion.

Premaxillary teeth in two series; outer series with four tricuspid teeth covering three internal teeth of inner series; inner row with five pentacuspid teeth. Maxilla long, of same width along entire length, with 2-3 tricuspid teeth set in anterior most part of ventral margin. Dentary with anterior four teeth pentacuspid, followed laterally by $8-10$ smaller teeth of increasing posterior inclination and reducing from tri to unicuspid, total number of lateral teeth quite variable.

Pored lateral-line scales 35(1), 37(6), 38(10), 39(4), 40(6), 41(1), 42(1) $(\mathrm{n}=29)$, scales between lateral line and origin of dorsal fin 7(27), 8(3) $(\mathrm{n}=30)$, scales between lateral line and origin of anal fin $8(4)$, $9(24)(n=28)$, scales between lateral line and pelvic-fin insertion 6(27), 7(3) $(n=30)$. Dorsal-fin rays iii 9(30), predorsal midline covered with medial, bilobed scales for more that $3 / 4$ of its length, naked anteriorly. Postdorsal profile convex, from last dorsal-fin ray to adipose-fin origin; first simple ray small, only visible in cleared and stained specimens; second simple ray about half length of third simple ray. Distal margin of dorsal fin slightly convex. Adipose-fin origin anterior to vertical through insertion of last anal-fin ray. Pectoral-fin rays i 11 ii (15), i 12(7) $(n=22)$. Anal-fin rays iv-v 24(1), 26(1), 27(6), $28(8), 29(5), 30(3), 31(1)(\mathrm{n}=27)$. Anal-fin origin posterior to vertical through insertion of last dorsalfin ray (Table 1). Caudal fin with 10 (6) leading principal rays in dorsal and ventral lobes, each lobes with $8(6)$ procurrent rays.

Total vertebrae 34(4), 35(2), including those of Weberian apparatus: 16(4)-17(2) precaudal centra, last three without ribs; caudal centra 18(4)-19(2). Epipleurals 20(4)-21(2). Epineurals 30(4), 31(2); posterior most epineural may reach anterior surface of urostyle. Hypurals 7(6), first dorsal hypural with anterior margin swollen, without projections that articulate with the urostyle; second and third hypurals with anterior margin swollen and contacting urostyle.
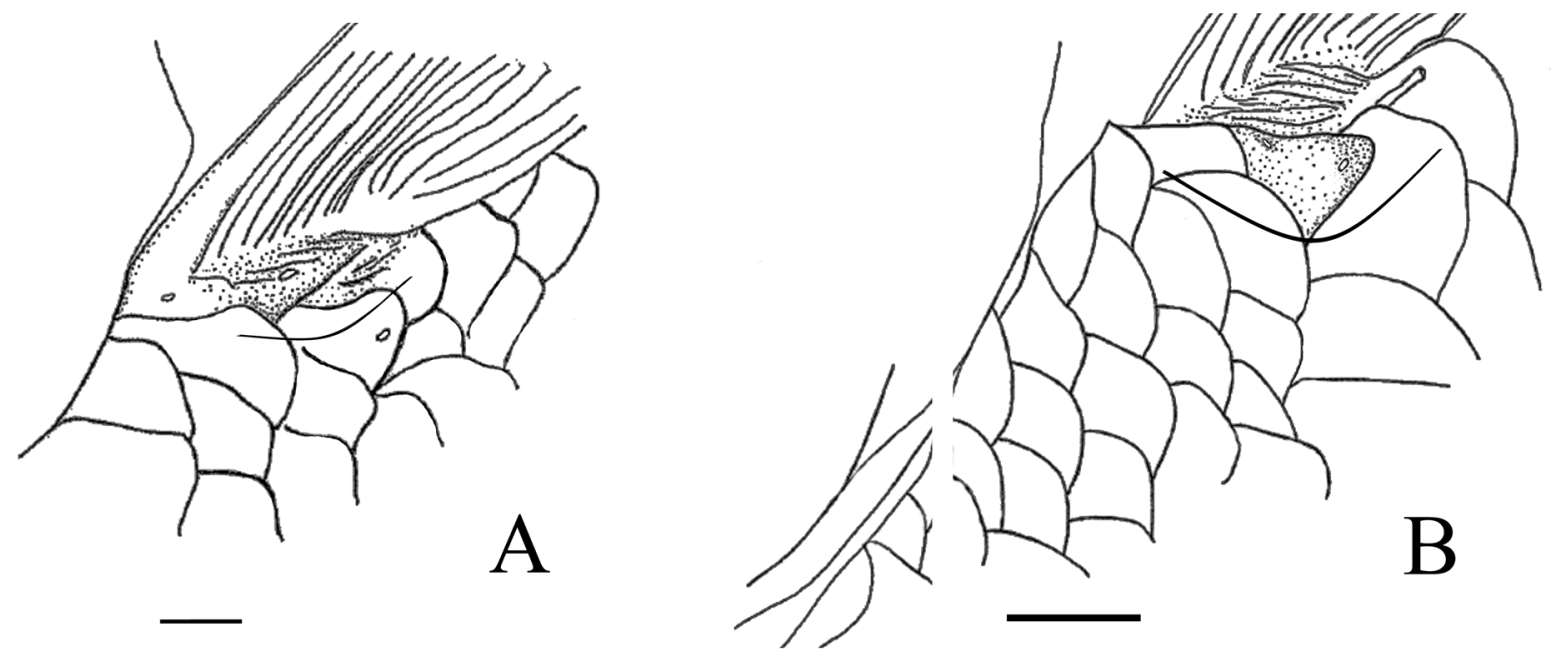

Fig. 9. Squamation of pectoral-fin base, ventral view. A. Astyanax bimaculatus (Linnaeus, 1758). B. Astyanax yariguies (Torres-Mejía, Hernández \& Senechal, 2012) comb. nov. In A, the pore of pectoral-fin is in epithelial tissue, covered or circumscribed by three scales indicated by the curved line, while in B, the pore of the base of pectoral-fin is part of a scale circumscribed by four scales, indicated by the curved line. Scale bars $=1 \mathrm{~cm}$. 


\section{Pigmentation in alcohol}

Sides of body yellowish, with reticulated pattern predominant over upper region of coelomic cavity, silvery stripe present from humeral region to caudal-peduncle base, overlain by series of chevronshaped marks formed by dark lines along myosepta between myotomes extending from dorsal region of coelomic cavity to caudal peduncle; pigmented muscle septae forming chevrons not coinciding with scale rows. Chevrons present in juveniles, immature specimens and adults, without distal extensions. Dorsal region of head and body chestnut brown. Sides of head and ventral surface of body light brown, not silvery. Melanophores of humeral region forming two spots. Anterior spot formed by two layers of pigment: brown melanophores distributed in a thin superficial layer of the epithelium (Layer 1, Fig. 1), deeper layer of dark melanophores (Layer 2, Fig. 1). Layer 2 forming a polygon-shaped spot, consisting of two groups of melanophores that do not precisely overlap, forming four-sided spot, extending from third to sixth or seventh scale of lateral line. Posterior humeral spot situated two or three scales posterior to the anterior humeral spot, arc- or sigmoid-shaped, inconspicuous, covering two to three scales above lateral line. Scales on sides of body with spots or dots. Spot on caudal peduncle pentagonal, located over lateral axis of peduncle, prolonged on posterior tips of middle caudal-fin rays, not extending to dorsal and ventral margins of caudal peduncle. Pectoral fins mostly hyaline, melanophores present on distal tips of pelvic-fin rays and interradial membranes of dorsal, caudal and anal fins.

\section{Sexual dimorphism}

Sexually dimorphic characters observed in one male, consisting of 7 to 12 small hooks located on distal portions of all branched anal-fin rays.

\section{Distribution}

Astyanax orthodus has been reported from the Pacific slopes of Central America (Angulo et al. 2013) and Colombia in South America (Torres-Mejía et al. 2012). However, based on the results of this study, A. orthodus occurs only in the lower Atrato River Basin, which flows into the Caribbean Sea in the Truando Department of north-western Colombia (Fig. 4). Populations identified as A. orthodus outside of the Atrato River Basin and similar to A. embera sp. nov., described herein, represent an as yet unrecognized new species.

\section{Astyanax superbus Myers, 1942}

Figs 4, 10, Table 2

Astyanax superbus Myers, 1942: 92, fig. 2. Original description, type locality: small brook tributary to Río Tamanaco at Camoruco, $20 \mathrm{~km}$ NE of San Carlos, Cojedes state, Venezuela.

\section{Diagnosis}

Astyanax superbus is a member of the orthodus species-group of Astyanax, differing from all other members of the group by the presence of longitudinal, wavy alternating dark and silver stripes on the sides of the body (vs pigment pattern reticulated, outlining scales, or sides of body uniformly pigmented) and the roughly rectangular shape of the caudal-peduncle spot, whose anterior margin diffusely fades out across the midlateral stripe, but does not surpass a vertical line through origin of the anal fin (vs spot on caudal peduncle extending anteriorly as a black stripe across the midlateral stripe reaching the humeral region in A. villwocki, or spot on caudal peduncle restricted to the caudal peduncle in A. orthodus and A. embera sp. nov.; or a conspicuous, rhomboid with short anterior extension that does not extend anteriorly beyond vertical line through origin of anal fin in $A$. bopiensis nom. nov.; or an inconspicuous spot on caudal peduncle in A. gandhiae sp. nov.). Astyanax superbus also has fewer epineurals than other members of the orthodus group (31-32 vs 33-34). It is distinguished from A. moorii comb. nov. 
by having the preanal distance less than $63 \%$ SL (vs more than $63 \% \mathrm{SL}$ ), the interorbital distance more $32 \% \mathrm{SL}$ (vs less than $32 \% \mathrm{SL}$ ) and the length of the upper jaw less than $32 \mathrm{HL}$ (vs more than $46 \% \mathrm{HL}$ ).

\section{Etymology}

The meaning of the name superbus was not explained in the original description. It is based on the Latin adjective 'superbus' meaning 'proud', probably used in a positive way, meaning 'magnificent', as in the English word 'superb'.

\section{Material examined}

\section{Holotype}

VENEZUELA: $79.4 \mathrm{~mm}$ SL, Cojedes State, Orinoco River Basin, small brook tributary to Tamanaco River at Camoruco, $20 \mathrm{~km}$ NE of San Carlos (SU 36489).

\section{Other material}

VENEZUELA: 1 specimen (sex unknown), $43.3 \mathrm{~mm}$ SL, 2 specimens (sex unknown) C\&S, 45.7$49.8 \mathrm{~mm}$ SL, Portuguesa State, Guache River, Portuguesa River drainage (INHS 28666); 2 specimens (sex unknown), 64.1-87.8 mm SL, 2 specimens (sex unknown) C\&S, 65.7-68.8 mm SL, Barinas State, Musao Uno Creek, Socopo-Barinas highway (MCNG 6350); 3 specimens (sex unknown), 67.370.4 mm SL, Portuguesa State, Guanare, Guache River at Garabote (MCNG 36349).

\section{Description}

Body compressed, greatest body depth at or anterior to dorsal-fin origin. Mouth terminal. Dorsal profile straight between snout tip and posterior tip of supraoccipital spine, convex between head and dorsal fin, convex between last dorsal-fin ray and adipose-fin origin. Caudal peduncle arched, with dorsal profile concave, ventral profile convex. Ventral profile convex from snout tip to posterior end of anal-fin base.

Premaxillary teeth in two series; outer series with four tricuspid teeth covering three most medial teeth of internal series; inner row with five pentacuspid teeth. Maxilla long, of same width along entire length, with 2-6 tricuspid teeth set in anterior most part of ventral margin. Dentary with anterior four teeth pentacuspid, followed by 10-12 teeth smaller, progressively inclined posteromedially, varying from trito unicuspid; proportion of tri- vs unicuspid teeth quite variable.

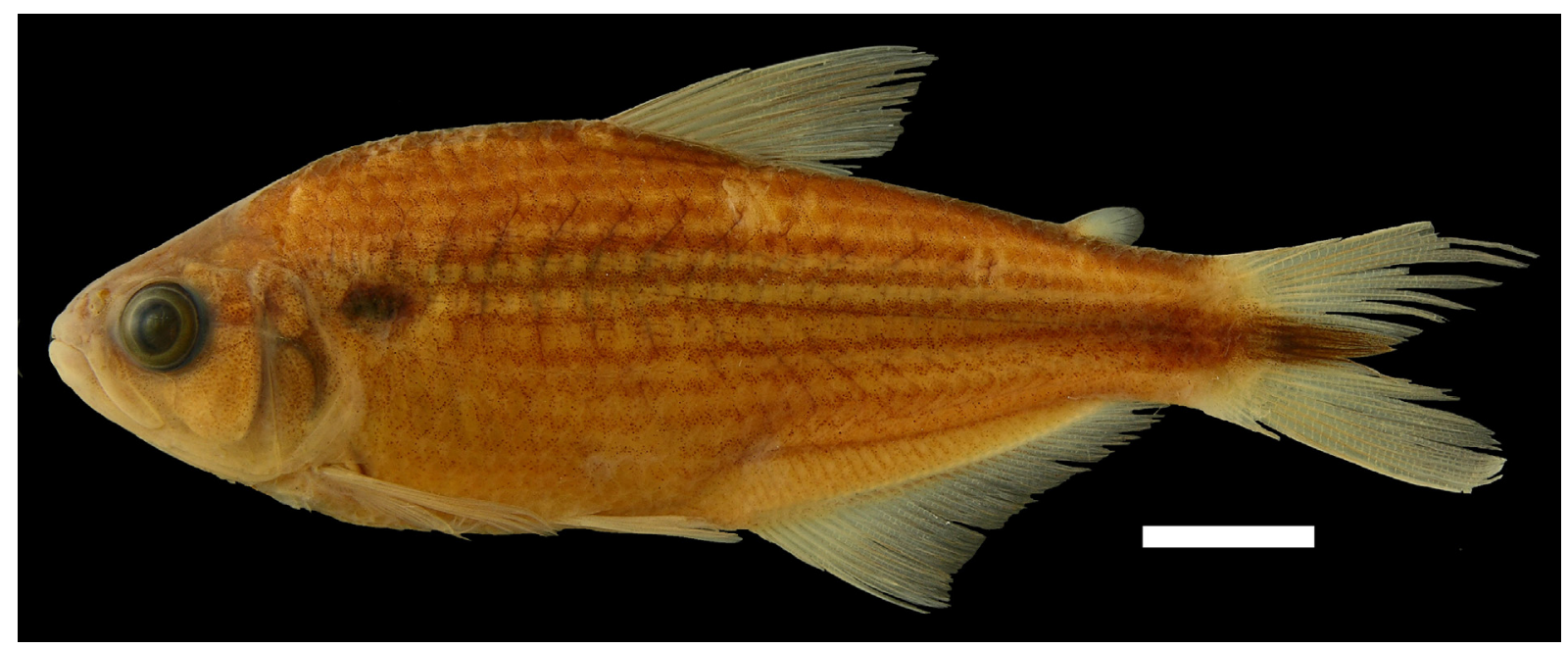

Fig. 10. Astyanax superbus Myers, 1942, $70.4 \mathrm{~mm}$ SL, Guache River, Garabote, Portuguesa state, Venezuela (MCNG 36349). Scale bar $=1 \mathrm{~cm}$. 
Pored lateral line scales 39(2), 40(3), 41(2), 42(1) $(\mathrm{n}=8)$; transverse scales from lateral line to origin of dorsal fin 7(4), 8(4) $(n=8)$; scales from lateral line to origin of anal fin 7(4), 8(4) $(n=8)$; scales from lateral line to insertion of pelvic fin $6(7), 7(1)(n=8)$. Predorsal midline series of scales incomplete; midline scales alternating with lateral scales overlapping on anterior two-thirds of predorsal series, continuous only in posterior part of predorsal area. Dorsal-fin rays iii $9(\mathrm{n}=8)$, first simple ray small, easily visible only in C\&S specimens, detectable in with dissecting needle in non-C\&S specimens $(\mathrm{n}=4)$; second simple ray about half length of third simple ray; distal margin of dorsal fin slightly convex. Adipose-fin origin anterior to vertical through insertion of last anal-fin ray. Pectoral-fin rays i 11(1), i12 (4), i 13(3) $(n=8)$. Anal-fin rays iii 27(3), iii 28(4), iii 29(1) $(n=8)$. First simple rays only visible in C\&S material. Anal-fin origin posterior to vertical through insertion of last dorsal-fin ray (Table 1). Caudal fin with 10 principal rays in both dorsal and ventral lobes; 11(4) procurrent rays in dorsal lobe, 9(3) or 10(1) in ventral. Upper 10(4) principal rays associated with four dorsal hypurals, $9(8)$ associated with three ventral hypurals.

Total vertebra 36(2), 37(2) $(n=4)$, including those of Weberian apparatus: precaudal centra 16(2), 17(2), the last three without true ribs; caudal centra 19(2), 20(2). Epipleurals 21(2), 22(2). Epineurals 31(2), 32(2); posterior-most epineural occasionally not reaching anterior surface of urostyle. Hypurals 7(4); first dorsal hypural with anterior margin swollen; first, second and third hypural with anterior margin swollen and contacting urostyle.

\section{Pigmentation in alcohol}

Sides of body yellowish, with thin silver and dark wavy stripes over the lateral surface of the body. Silver stripe present from humeral region to caudal peduncle base, overlain by series of chevron-shaped marks formed by dark lines along myosepta between myotomes extending from dorsal region of coelomic cavity to caudal peduncle; pigmented muscle septae forming chevrons not coinciding with scale rows. Chevrons without distal extensions both in juvenile and adult specimens.

Dorsal region of head and body chestnut brown. Sides of cranium and ventral surface of body light brown, not silvery. Melanophores of humeral region forming two spots. Anterior spot formed by two layers of pigment: brown melanophores distributed in a thin superficial layer of the epithelium (Layer 1, Fig. 1), deeper layer of dark melanophores (Layer 2, Fig. 1). Layer 2 typically forms polygon shaped spot, consisting of two groups of melanophores that do not precisely overlap, forming four-sided spot extending from third to sixth or seventh scale of lateral series. Posterior humeral spot situated two or three scales posterior to the anterior humeral spot, arc- or sigmoid-shaped, inconspicuous, covering two to three scales above lateral-line. Caudal-peduncle spot roughly rectangular, with anterior margin diffuse, not extending anteriorly beyond vertical through anal-fin origin. Dorsal, pectoral, pelvic and anal fins hyaline.

\section{Sexual dimorphism}

Undetected in examined adults.

\section{Distribution}

This species is present in upland tributaries of the Apure River, a left-margin tributary to the Orinoco River in Venezuela (Fig. 4).

Astyanax villwocki Zarske \& Géry, 1999

Figs 4, 11, Table 2

Astyanax villwocki Zarske \& Géry, 1999: 200, figs 1-2. Original description, type locality: Rio Pacal, Rio Pachitea Basin, Departamento Ucayali, Peru. 


\section{Diagnosis}

Astyanax villwocki is a member of the orthodus species-group of Astyanax differing from the other members of the group by the absence of a distinct caudal-peduncle spot (vs present) and having instead a dark stripe, continuing anteriorly to the humeral region (vs absent).

\section{Etymology}

Named after Prof. Wolfgang Villwock, Hamburg, who collected some of the first specimens of the type material, including the holotype, and made them available for study.

\section{Material examined}

\section{Holotype}

PERU: 98.1 mm SL, Ucayali, Peruvian Amazon Basin, Pachitea River drainage, Pacal River (MTD F 22400).

\section{Other material}

PERU: 1 + , $118.8 \mathrm{~mm}$ SL, Ucayali department, Coronel Portillo province, Instituto Veterinario de Investigaciones Tropicales y de Altura (IVITA) Ivita Piscigranja, Pucallpa, Ucayali (MUSM 148); 1 , 43.6 mm SL, Madre de Dios department, Manu Province, Manu National Park Manu River, Pakitza Lavandería Creek (MUSM 2285); 4 우, 43.4-54.4 mm SL, Madre de Dios, Manu, Manu National Park, Picaflor Creek (MUSM 2499); 8 우, 33.2-42.6 mm SL, Madre de Dios, Manu, PNM, Picaflor Creek (MUSM 4288); 2 우, 50.4-101.6 mm SL, Cusco, La Convención, Echarate, Urubamba River, quebrada Hayanamato (MUSM 14461); 16 우, 55.1-95.5 mm SL, Loreto, Ucayali, Rashaya,Víbora Creek, Pisqui River Basin (MUSM 15881); 1 , , 69.3 mm SL, Loreto, Corrientes River, Andoas (MUSM

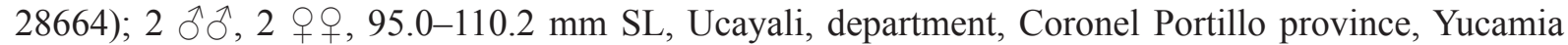
River, Ucayali River Basin (MUSM 33560); 1 ㅅ, 4 우 ㅇ, 98.2-112.5 mm SL, Ucayali, Coronel Portillo, Pucallpa Pichaya River (MUSM 33609); 1 ð, 122.3 mm SL, Loreto, Maynas, Pucacuro River, $175 \mathrm{~m}$

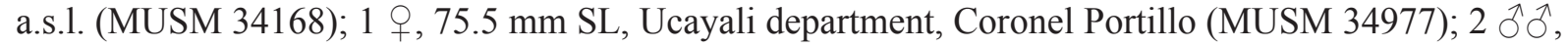
114.6-115.8 mm SL, Ucayali, Coronel Portillo, Blanca stream, Ucayali River Basin (MUSM 34994).

COLOMBIA: 1 †, 87.9 mm SL, Caquetá, Yurayaco, Amazon River Basin, Inchiyaco River, on the road from Villa Garzón to San José de Fragua (IUQ 121); 1 \%, 84.3 mm SL, Caquetá, Yurayaco River, on the road from Yurayaco to Villa Garzón (IUQ 180); 1 q C\&S, 60.4 mm SL, Caquetá, Creek tributary

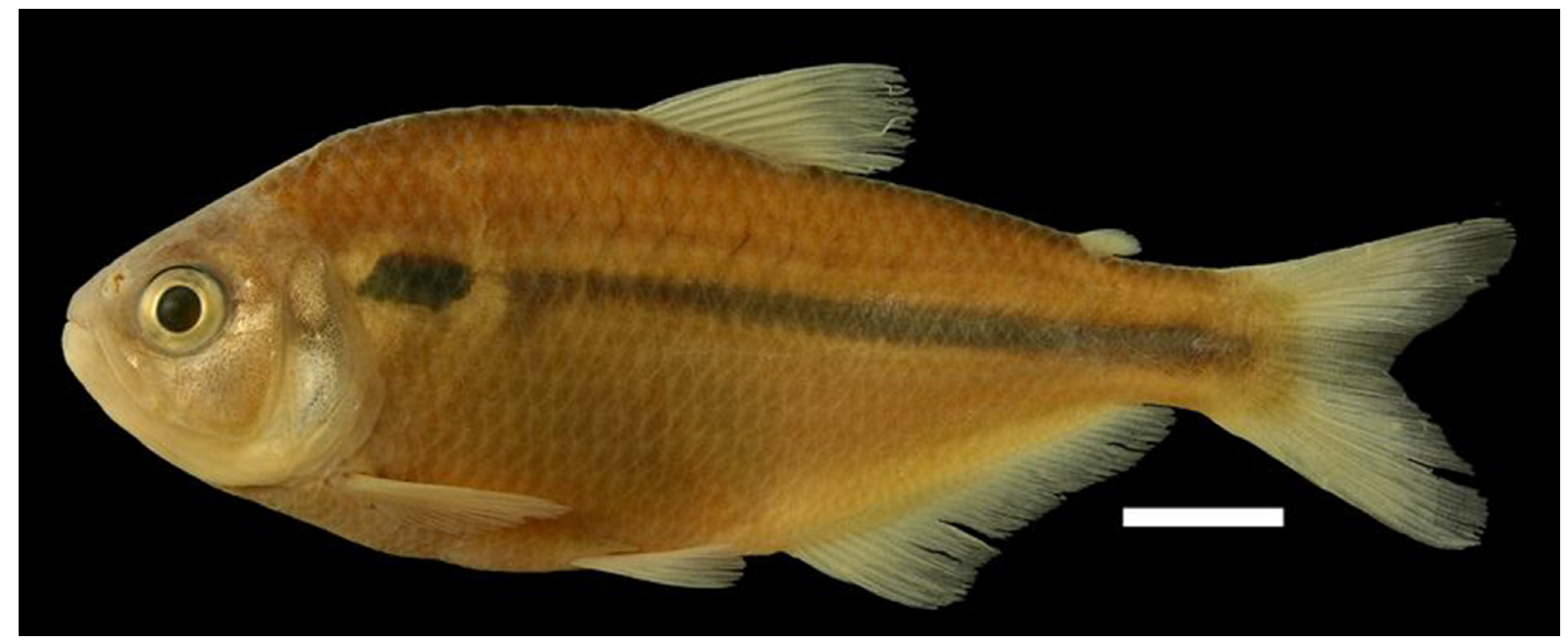

Fig. 11. Astyanax villwocki Zarske \& Géry, 1999, 74.7 mm SL, Caquetá River, Colombia (IUQ 3593). Scale bar $=1 \mathrm{~cm}$. 
Yurayaco River, road Villa Garzón (IUQ 1218); 1 ð, 96.5 mm SL, Putumayo, Amazon River Basin, Orito Creek, south of the farm La Palma, ca $1 \mathrm{~km}$ from the Guamez River, vereda Calimonte, Orito (IUQ 1871); 1 đ, 47.4 mm SL, Caquetá, Amazon River Basin, Yurayaco River, in the village Yurayaco (IUQ 1893); 1 ô, $63.5 \mathrm{~mm}$ SL, Pazalosa Creek, village in Usmo, Caquetá River (IUQ 1888); 1 + , $77.7 \mathrm{~mm}$ SL, Caquetá (IUQ 3593).

ECUADOR: 1 ऽ, 2 우, 71.3-80.4 mm SL, Napo, Sunka flooded area ("estero") at 20 minutos or $0.5 \mathrm{Km}$ from Sunka Well (MEPN 2723); 3 +, , $72.3 \mathrm{~mm}$ SL, Napo, Sunka flooded area ("estero") at 20 minutos or $0.5 \mathrm{Km}$ from Sunka Well (MEPN 2769); 1 ㅇ, $13.4 \mathrm{~mm}$ SL, Pastaza, Santi flooded area ("estero") at $2 \mathrm{Km}$ from Manalí Well at la Trucha No. 3 (MEPN 6176); 2 +,$+ 116.0-118.9 \mathrm{~mm}$ SL, 1 ㅇ C\&S, $111.5 \mathrm{~mm}$ SL, Pastaza, Danta River $500 \mathrm{~m}$ from the exploration platform (MEPN 6180); 1 o , 3 우우, 81.5-91.7 mm SL, 1 ○ C\&S, 72.3 mm SL, Amazon River Basin, Sovelca flooded area ("estero"), tributary Napo River (MEPN 6186); 1 +, $88.52 \mathrm{~mm}$ SL, Sucumbios, 300 m, Bocapore River to $2 \mathrm{~km}$, at

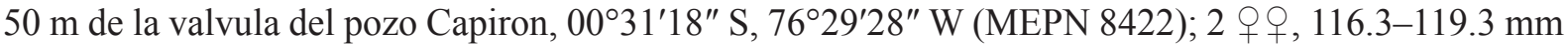
SL, Yeye River, $200 \mathrm{~m}$ from head of Ginta Well, Sucumbios (MEPN 9560).

\section{Description}

Body compressed, greatest body depth at or anterior to dorsal-fin origin. Mouth terminal. Dorsal profile straight between snout tip and posterior tip of supraoccipital spine, straight between supraoccipital spine and dorsal-fin origin, convex between head and at base of dorsal fin, convex between last dorsal-fin ray and adipose-fin origin. Caudal peduncle arched, with dorsal profile concave, ventral profile convex. Ventral profile convex from tip of snout to pelvic-fin insertion.

Premaxillary teeth in two series; outer series with four tricuspid teeth covering three most medial teeth of inner series; inner row with five pentacuspid teeth. Maxilla long, of same width along entire length, with 3-5 tricuspid teeth set in anterior most part of ventral margin. Dentary with anterior four teeth pentacuspid, followed by 7-9 teeth smaller, progressively inclined posteromedially, varying from tri- to unicuspid; proportion of tri- vs unicuspid teeth quite variable.

Pored scales of lateral line 39(4), 40(4), 41(6), 42(3), 44(1) $(n=18)$; transverse scales between lateral line and origin of dorsal fin 7(18), 8(1) (n=19); scales between lateral line and origin of anal fin 6(3), 7(15) $(\mathrm{n}=18)$; scales between lateral line and insertion of pelvic fin 6(13), 7(5) $(\mathrm{n}=18)$. Predorsal midline covered with bilobed medial scales for more than $3 / 4$ of its length, naked anteriorly. Rays of dorsal fin iii 9 $(\mathrm{n}=18)$; first simple ray small, easily visible only in C\&S specimens, detectable with dissecting needle in non-C\&S specimens; second simple ray about half length of third simple ray. Distal margin of dorsal fin slightly convex. Origin of adipose fin anterior to vertical line through insertion of last anal-fin ray. Rays of pectoral fin i 12(8), i 13(10) $(n=18)$. Rays of anal fin iii 25(10), iii 26(7), iii 27(2); first simple rays only visible in $\mathrm{C} \& \mathrm{~S}$ material. Origin of anal fin posterior to vertical line through insertion of last ray of dorsal fin. Caudal fin with 9(1), 10(2) principal rays in dorsal lobe and 10(1), 11(2) in ventral lobe, dorsal lobe with 10(3) procurrent rays, ventral with 8(2), 9(1). Principal rays of dorsal lobe associated with four dorsal hypurals, those of ventral lobe associated with three ventral hypurals.

Total vertebrae 36(1), 37(2), including those of the Weberian apparatus: precaudal centra 17(1), 18(2); last two vertebrae modified with elongate transverse process not in contact with dorsal tip of its rib; caudal centra 19(3). Epipleurals 21(1), 22(2). Epineurals 30(1), 32(2), posterior-most epineural occasionally reaching anterior surface of urostyle. Hypurals 7(3); first dorsal hypural with anterior margin swollen, without projections that articulate the urostyle; second and third hypural dorsal with anterior margin swollen that contacting urostyle. 


\section{Pigmentation in alcohol}

Sides of body yellowish, without reticulated pattern over the lateral surface of the body. Dark lateral stripe from humeral region to caudal-peduncle base, overlain by series of chevron-shaped marks formed by dark lines along myosepta between myotomes extending from anterior third of anal fin; only distal tips of chevrons located to midlateral stripe visible, chevron-shaped marks less evident in adults $(\geq 3 \mathrm{~cm}$ SL). Pigmented muscle septae that form series of chevrons not coinciding with horizontal rows of scales, not aligned with scale edges. Chevrons present in juveniles, immature specimens and adults, without distal extensions.

Dorsal region of head and body chestnut brown. Sides of cranium and ventral surface of body light brown, not silvery. Melanophores of humeral region forming two spots. Anterior spot formed by two layers of pigment: brown melanophores distributed in thin superficial layer of the epithelium (Layer 1, Fig. 1), deeper layer of dark melanophores (Layer 2, Fig. 1). Layer 2 forms a polygon-shaped spot consisting of two groups of melanophores that do not precisely overlap, typically forming four-sided spot. Second humeral spot located one scale posterior to anterior humeral spot, arc- or sigmoid-shaped, inconspicuous, covering two to three scales above lateral line. Spot on caudal peduncle absent. Pectoral fins mostly hyaline; melanophores present on distal tips of pelvic-fin rays and interradial membranes of dorsal, caudal and anal fins.

\section{Sexual dimorphism}

Distribution of hooks on fins varying from 12-16 in the pelvic fin, 15-17 in the anal fin; males with longer unbranched rays in dorsal, pectoral and pelvic fins; distal tips of latter two fins extend posteriorly to pelvic-fin origin and anal-fin insertion, respectively.

\section{Distribution}

Amazon River drainages of Peru, Ecuador and Colombia (Fig. 4).

\section{Comments on type specimens of Astyanax villwocki}

Astyanax villwocki was described by Zarske \& Géry (1999) based on specimens from the drainages of the Pachitea River in Peru, the Beni River in Bolivia and the Madeira River. However, examination of the type specimens revealed differences among specimens included in the original description. Specimens from the Madeira River (MTDF 2214- 22115; ZFMK 20781) do not have the diagnostic characters of A. villwocki; they lack the lateral stripe (vs dark lateral stripe present) and have a series of chevrons extending along the entire lateral stripe (vs chevron series not surpassing anterior third of anal fin). We therefore re-identify the specimens from the Madeira River as Astyanax boliviensis sp. nov.

Astyanax yariguies (Torres-Mejía, Hernández \& Senechal, 2012) comb. nov.

Figs 4, 12, Table 1

Astyanacinus yariguies Torres-Mejía, Hernández \& Senechal, 2012: 501-506, figs 1-2. Original description, type locality: Rio Cascajales, Colombia.

\section{Diagnosis}

Astyanax yariguies is a member of the orthodus species-group of Astyanax, differing from the other members of the group, except for $A$. orthodus, in having a short polygonal caudal-peduncle spot (vs a cane-shaped mark that extends anteriorly to a vertical through the posterior anal-fin tip in A. superbus, an elongate mark that extends anteriorly to the humeral region in $A$. villwocki, and a short nail-shaped spot in $A$. bopiensis nom. nov. and A. boliviensis sp. nov.; spot on caudal peduncle inconspicuous 
in $A$. gandhiae sp. nov., and spot on caudal peduncle pentagonal, but extended towards dorsal and ventral margins of peduncle in $A$. embera sp. nov.). It differs from $A$. orthodus by the greater number of maxillary teeth (6 vs 2-3). It differs from most species of the orthodus-group in having 9-10 series of scales between the dorsal-fin origin and the lateral line (vs 7-8, except for A. bopiensis nom. nov. with $7-10$ ). It is distinguished from $A$. moorii comb. nov. by orbital diameter greater than $31 \% \mathrm{HL}$ (vs less than $31 \% \mathrm{HL}$ ), interorbital distance more $32 \% \mathrm{HL}$ (vs less than $32 \% \mathrm{HL}$ ) and upper jaw length less than $35 \%$ HL (vs more than $45 \%$ HL).

\section{Etymology}

The species name refers to the Yariguíes, the indigenous group that inhabited an area that includes the watershed of the Cascajales River. They fiercely defended their pristine territory for more than 400 years, which likely contributed to the preservation of the species described here. The Yariguíes finally succumbed to invasion and extermination in the mid- $20^{\text {th }}$ century. The species name is treated as a noun in apposition (Torres-Mejía et al. 2012).

\section{Type material}

Holotype (not examined)

COLOMBIA: 61.9 mm SL, Santander, El Carmen, Magdalena River system (Atlantic coast), Cascajales River drainage, Sucio River, under bridge on the road from El Carmen to Vereda Island (UIST 1752).

\section{Material examined}

\section{Paratypes}

COLOMBIA: 1 đ, 6 우, 41.9-72.2 mm SL, Santander, Islandia locality, Magdalena River Basin, La Concordia Creek, 6³5'22.3" N, 7334'58.1" W (ICNMNH 17642).

\section{Description}

Body compressed, greatest body depth at or anterior to origin of dorsal fin. Mouth terminal. Dorsal profile sigmoid between snout tip and posterior margin of supraoccipital spine (anterior part convex, posterior part concave), convex between head and dorsal fin, convex between head and at dorsal-fin

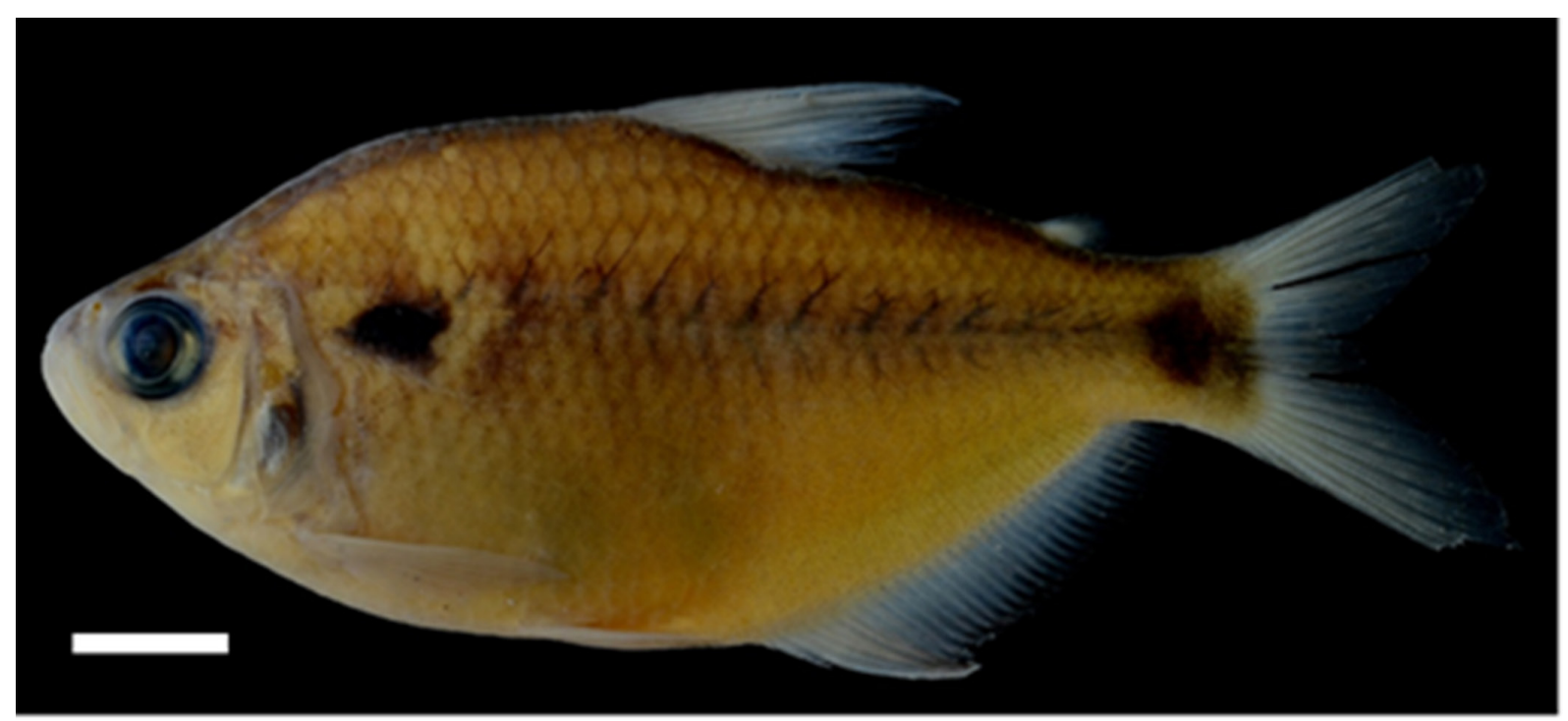

Fig. 12. Astyanax yariguies (Torres-Mejía, Hernández \& Senechal, 2012) comb. nov., paratype, 75.5 $\mathrm{mm}$ SL, La Concordia Creek, Santander, Colombia (ICNMNH 17642). Scale bar $=1 \mathrm{~cm}$. 
base, convex between last ray of dorsal fin and origin of adipose fin. Caudal peduncle with straight dorsal and ventral profiles. Ventral profile convex between snout tip and insertion of pelvic fin.

Premaxillary teeth in two series; outer series with four tricuspid teeth covering three most medial teeth of inner series; inner row with five pentacuspid teeth. Maxilla long, of same width along entire length, with 2-3 tricuspid teeth set in anterior most part of ventral margin. Dentary with anterior four pentacuspid teeth, followed laterally by $8-10$ teeth smaller, progressively inclined posteromedially, varying from tri- to unicuspid; proportion of tri- vs unicuspid teeth quite variable.

Pored lateral line scales 39(2), 40 (4); transverse scales from lateral line to dorsal-fin origin 9(1), 10 (5); scales from lateral line to anal-fin origin 7(1), 8(3), 9 (2); scales from lateral line to pelvic-fin insertion 6(1), 7(3), 8(2). Predorsal midline covered with bilobed medial scales for more than $3 / 4$ of its length, naked anteriorly. Dorsal-fin rays iii 9 (6), first simple ray small, easily visible only in C\&S specimens, detectable with dissecting needle in non-C\&S specimens; second simple ray about half length of third simple ray. Distal margin of dorsal fin slightly convex. Origin of adipose fin anterior to vertical through insertion of last ray of anal fin. Rays of pectoral fin i 10 (1), i 11(1). Rays of pelvic fin i 7(2). Rays of anal fin iii 28-30(8), first simple rays only visible in cleared and stained material (Table 1). Origin of anal fin posterior to vertical line through insertion of last dorsal-fin ray.

Total vertebrae 32(1), 35(1), including those of the Weberian apparatus: precaudal centra 16(1), 17(1); last three without pleural ribs; caudal centra 17(1)-19(1). Epipleurals 19-20. Epineurals 30-31, posterior-most epineural occasionally reaching anterior surface of urostyle. Hypurals 7 (2); first dorsal hypural with anterior margin swollen, without projections articulating with urostyle; second and third hypural with anterior margin swollen, contacting urostyle.

\section{Pigmentation in alcohol}

Sides of body yellowish, with reticulated pattern predominant over the lateral surface of the body. Silvery stripe between humeral region and caudal fin, overlain by series of chevron-shaped marks formed by dark lines along myosepta between myotomes extending from upper region of coelomic cavity to caudal peduncle; pigmented muscle septae forming chevrons not coinciding with scale rows. Chevrons without distal extensions both in juvenile and adult specimens.

Dorsal region of head and body chestnut brown. Sides of cranium and ventral surface of body light brown, not silvery. Melanophores of humeral region forming two spots. Anterior spot formed by two layers of pigment: brown melanophores distributed in a thin superficial layer of the epithelium (Layer 1, Fig. 1), deeper layer consisting of dark melanophores (Layer 2, Fig. 1). Layer 2 forms a polygon shaped spot, consisting of two groups of melanophores that do not precisely overlap, typically forming foursided spot extending from third to sixth or seventh scale of lateral series. Posterior humeral spot situated two or three scales posterior to the anterior humeral spot, arc- or sigmoid-shaped, inconspicuous, covering two to three scales above lateral-line. Caudal-peduncle spot short, elliptical in shape, not extending anteriorly to vertical through posterior margin of adipose fin. Pectoral, pelvic, dorsal and anal fins hyaline. Pigment present on interradial membranes of middle caudal-fin rays.

\section{Sexual dimorphism}

Males with small hooks on distal tips of rays of all fins: dorsal fin with hooks on third simple ray and on all branched rays; pelvic, anal and pectoral fins with hooks on branched rays; caudal fin with hooks on four middle rays. 


\section{Taxonomic comments}

This species is transferred from Astyanacinus to Astyanax because it shares the anteriorly directed V-shaped chevrons along myomere junctions with members of the orthodus species-group. The conspicuous polygon-shaped humeral spot is also similar (Fig. 1), consisting of dark melanophores.

\section{Distribution}

Astyanax yariguies is known from Colombia, the Magdalena River Basin and the Cascajales River drainage (Fig. 4).

Astyanax moorii (Boulenger, 1892) comb. nov.

Figs 4, 13, Table 2

Tetragonopterus moorii Boulenger, 1892: 11, pl. 2 fig. 1. Original description, type locality: Chapala Plateau, Mato Grosso State, Brazil.

Astyanacinus moorii - Eigenmann 1910: 435; Pearson 1924: 41. (Beni River Basin at Tumupasa; Popoi River, Upper Beni; Ixiamas; Huachi; Rurrenabaque).

\section{Diagnosis}

Astyanax moorii comb. nov. is a member of the orthodus species-group of Astyanax, differing from other species of the group in having an inconspicuous spot in the caudal peduncle (vs conspicuous peduncle spot) and by the length of the upper jaw more than $47 \% \mathrm{HL}$ (vs less than $47 \% \mathrm{HL}$ ), and from A. orthodus, A. superbus, A. yariguies and A. gandhiae sp. nov. in the interorbital distance being 27.4$31.4 \% \mathrm{HL}$ (vs $>32 \% \mathrm{HL}$ ); it is distinguished from A. bopiensis nom. nov. and A. gandhiae sp. nov., A. orthodus and A. embera sp. nov. by the distance between the dorsal and pectoral fins $37.4-40.3 \% \mathrm{SL}$ (vs more than $40.4 \mathrm{SL}$ ); from $A$. villwocki by the absence of a dark band on the side surface of the body (vs present) and from A. bopiensis nom. nov. by the maxillary length $34.0-37.9 \%$ HL (vs $46.7-58.9 \%$ HL).

\section{Etymology}

The specific epithet moorii refers to the collector Mr. Spencer le Marchant Moore, who collected the type material of Astyanax moorii comb. nov.

\section{Type material}

Lectotype (examined from photograph)

BRAZIL: 1 specimen, $65.2 \mathrm{~mm}$ SL; Upper Paraguay Chapala Plateau, Mato Grosso State (BMNH 1892.4.20.51; photo BMNH 1892-4-20-51-2 2).

\section{Paralectotype}

BRAZIL: 1 specimen, SL unknown; Upper Paraguay Chapala Plateau, Mato Grosso State (BMNH 1892.4.20.52; photo BMNH 1892-4-20-51-2 1).

\section{Material examined}

BRAZIL: State of Mato Grosso: 2 specimens (sex unknown), 50.3-64.7 mm SL, stream ("riacho") near Manso Hydro-Electric Plant, Cuiabá River Basin, in the region of Fazenda Nova (MNRJ 29284); 3 specimens (sex unknown), 43.2-59.0 mm SL, Forte Stream ("ribeirão"), tributary of the Coxipó-Açu River, Cuiabá River Basin, Municipality of Cuiabá (MNRJ 1190). 


\section{Description}

Body compressed, greatest body depth at or anterior to dorsal-fin origin. Mouth terminal. Anterior half of dorsal profile of head slightly straight; profile between posterior margin of supraoccipital spine and dorsal-fin origin as between last dorsal-fin ray and adipose-fin origin is slightly convex. Dorsal and ventral margins of caudal peduncle straight. Ventral profile convex from tip of snout to pelvic-fin insertion, feature visible in both sexes.

Premaxillary teeth in two series; outer series with three to five tricuspid teeth, so the outer lateral tooth; inner tooth row with five pentacuspid teeth. Maxilla with three to four teeth in anterior-most part of ventral margin. Dentary with four anterior teeth pentacuspid, followed laterally by 6-10 smaller teeth of increasing posterior inclination, reducing from tri- to unicuspid.

Pored scales of lateral line 41(1), 44(2), 45(1), 46(1), 47(1), 50(1), $(n=7)$, transverse scales from lateral line to origin of dorsal fin 8(5) a $9(2)(n=7)$, scales from lateral line to origin of anal fin $6(1), 7(5), 8(1)$ $(n=7)$, scales from lateral line to insertion of pelvic fin $6(5), 7(2),(n=7)$. Predorsal midline covered with bilobed medial scales for more than $3 / 4$ of its length, naked anteriorly. Rays of dorsal fin iii 9 ( $n=$ 7); first simple ray small, only visible in cleared and stained specimens; second simple ray about half length of third simple ray. Distal margin of dorsal fin slightly convex. Origin of adipose fin anterior to vertical line through insertion of last ray of anal fin. Rays of pectoral fin i 12(1), i 13(5), i 14(1). Pelvicfin rays i 6(1), i 7(6). Rays of anal fin iii(2), iv(v) and 28(1), 29(4), 30(1) and 32(1), first simple rays only visible in cleared and stained material. Origin of anal fin posterior to vertical line through insertion of last dorsal-fin ray.

Caudal-fin rays 10-9, dorsal lobe with 11(5), 13(2) procurrent rays, ventral with 10(7) procurrent radios. Upper 10(5) principal rays of caudal fin associated with four dorsal hypurals, next 9(2) associated with three ventral hypurals and last principal ray associated with last hemal spine. Total vertebrae 37(3), including those of the Weberian apparatus: precaudal centra 15(2) y 16(1), last two without true pleural rib. Caudal centra 19(2), 20(1). Epineurals 36(1), 38(2), 40(1), 41(1) posterior-most epineural may not reach anterior surface of urostyle; epipleurals 20(5). Caudal skeleton with seven hypurals. First three hypurals with swollen anterior margins in contact with urostyle.

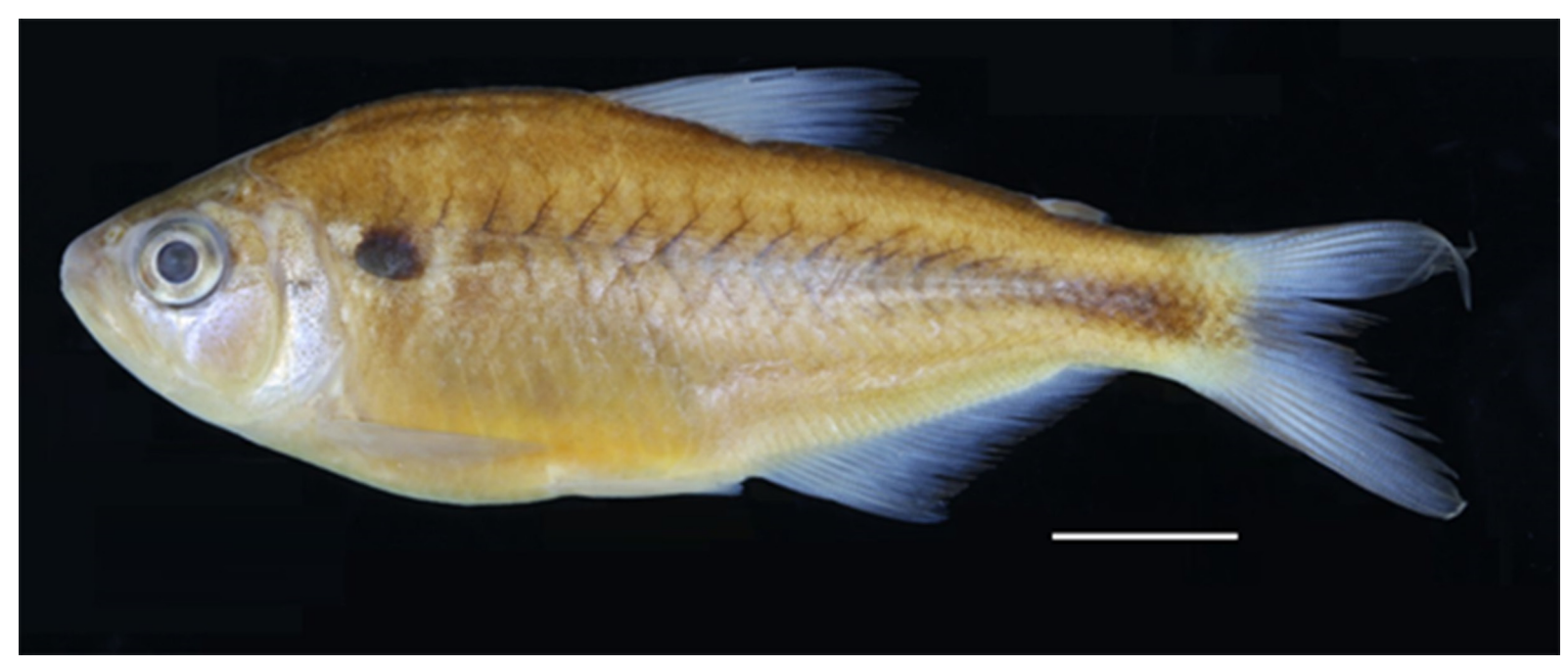

Fig. 13. Astyanax moorii (Boulenger, 1892), $64.7 \mathrm{~mm}$ SL, Creek near the Manso Hydroelectric Plant, Cuiabá River drainage, Fazenda Nova region, Mato Grosso State, Brazil (MNRJ 29284). Scale bar = $1 \mathrm{~cm}$. 


\section{Pigmentation in alcohol}

Sides of body yellowish, without reticulated pattern, with silver midlateral stripe present from humeral region to caudal-peduncle base, overlain by series of chevron-shaped marks formed by dark lines along myosepta between myotomes extending from dorsal region of coelomic cavity to caudal peduncle; pigmented muscle septae forming chevrons not coinciding with scale rows. Chevrons with distal extensions both in juvenile and adult specimens.

Dorsal region of head and body chestnut brown. Sides of cranium and ventral surface of body light brown, not silvery. Melanophores of humeral region forming two (anterior and posterior) humeral spots. The anterior spot is formed by two layers of pigment, with brown melanophores distributed in thin superficial layer of the epithelium (Layer 1, Fig. 1); deeper layer that with dark melanophores (Layer 2, Fig. 1). Layer 2 forming polygon-shaped spot, with two parts, forming vertices on margins, usually forming four-sided spot located from second to fifth or sixth scale of lateral series. Posterior humeral spot situated two scales posterior to anterior humeral spot, rectangle-shaped, inconspicuous and covering two to three scales above lateral-line. Individual scales on sides of body without spots or dots. Caudalpeduncle spot rhomboid with short anterior extension over silver lateral stripe not surpassing anal-fin origin, dark pigment of caudal peduncle stripe continued on to middle caudal-fin rays with dark pigment present on tips of remaining rays. Pectoral, pelvic, dorsal and anal fins hyaline.

\section{Sexual dimorphism}

No sexual dimorphism was observed, no hooks found on fins.

\section{Taxonomic comments}

This species is transferred from Astyanacinus to Astyanax because it shares the anteriorly directed V-shaped chevrons along myomere junctions with members of the orthodus species-group. The conspicuous polygon-shaped humeral spot is also similar (Fig. 1), consisting of dark melanophores.

\section{Distribution}

Known from the Alto Paraguay River in Brazil (Fig. 4).

\section{Discussion}

Our comparisons among members of the Astyanax orthodus group demonstrated that pigmentation characters are useful to differentiate species from different hydrographic drainages. The great morphological similarities among species from the Pacific, Orinoco and Amazon drainages makes it difficult to differentiate the taxa. However, pigmentation and osteological characters indicate a diversification that may be due to differences in habitat as well as geographic isolation (Schluter 2000; Martin \& Pfennig 2009). On the other hand, differences in body shape among the species of the Madre de Dios River in the Amazon Basin may be related to differing water velocities (Langerhans et al. 2003).

The allopatric pattern of distribution exhibited by the nine species recognized in this study is consistent with a hypothesis of geographic isolation as the main factor leading to diversification within the orthodus species-group. This hypothesis is also consistent with our observation that morphology and pigmentation patterns are most similar between species in adjacent drainages. This is the case on the Pacific coast where we find A. villwocki and A. embera sp. nov., and for the Orinoco and Amazon Basins where $A$. superbus and $A$. gandhiae sp. nov. occur in adjacent areas.

The high diversity of Astyanax, recognized as a subfamily by Van Der Laan et al. (2014), has been related to morphotypes and pigmentation patterns in the humeral and caudal peduncle regions in this study. Given the rampant parallelism observed in characters used in the taxonomy of the family Characidae 
(Mirande 2010), the description and recognition of pigmentation characters in the humeral region was proposed as new in related genera of Characidae, as well as the distribution of scales in the predorsal area and along the base of the anal fin. Garutti \& Langeani (2009) proposed the establishment of two subgroups within the bimaculatus species-group: one for those species that have a black lateral stripe from the humeral region to the caudal peduncle and another for those with the caudal spot limited to the caudal peduncle. The orthodus clade could correspond to a new clade within the bimaculatus group, as indeed it is suggested in the phylogenetic hypothesis proposed by Calgagnotto et al. (2005) and Schmitter-Soto (2016).

In spite of the complexity of species diagnosis among cryptic species, pigmentation characters used here were useful to differentiate species from different hydrographic drainages. The great similarity of the species from the Pacific, Orinoco and Amazon drainages makes it difficult to differentiate the taxa. However, pigmentation and osteological characters indicate a diversification that may be due to differences in habitat as well as to geographic isolation (Schluter 2000; Martin \& Pfennig 2009).

The hypothesis of phylogenetic relationships among Characidae proposed by Mirande $(2009,2010)$ and based on morphological and pigmentation characters included eighteen species of Astyanax, but did not include any species of Astyanacinus. Mirande $(2009,2010)$ provisionally regarded Astyanacinus as incertae sedis, noting that it has characters that support conflicting relationships with either the Astyanax clade or the Hyphessobrycon luetkeni clade. One character in particular supports the relationship between species of Astyanax and Astyanacinus: the horizontally elongated, roughly oval humeral spot with sharp, well delimited margins and bordered anteriorly and posteriorly by light regions, mostly devoid of melanophores. The species sharing this character were recognized as members of the Astyanax bimaculatus-group (Mirande 2010), including species (e.g., A. villwocki, A. superbus, A. orthodus), which are included in the Astyanax orthodus subgroup, as defined in the present study. Mirande (2010) also noted that the main character (maxilla long and not forming an angle with the premaxilla) regarded as diagnostic of Astyanacinus by Eigenmann (1921) is found in other species traditionally included in Astyanax, which we include here in the Astyanax orthodus clade (A. villwocki, A. superbus, A. orthodus). Species of Astyanacinus also lack several characters present in members of the Hyphessobrycon luetkeni clade, including the reduction of the lateral line. Thus, considering the totality of characters, it is more parsimonious to hypothesize that the lateral chevron marks of Hyphessobrycon bifasciatus were acquired independently, whereas the chevron marks present in species of Astyanacinus represent an apomorphic trait shared with members of the Astyanax bimaculatus-group.

Astyanax yariguies was assigned to the genus Astyanacinus because it was reported to have a continuous series of scales on the predorsal midline: "with 13 scales (vs 14 scales; 16 in Astyanacinus multidens and 15 in Astyanax superbus)" (Torres-Mejía et al. 2012). Our observations, however, do not confirm that statement. We observed very few scales present on the predorsal midline in A. yariguies, A. superbus, A. bopiensis nom. nov., A. villwocki, A. orthodus and A. embera sp. nov. The incompleteness of the predorsal series of scales and the presence of chevron marks in A. yariguies are thus interpreted as nested synapomorphies justifying the inclusion of A. yariguies in the Astyanax orthodus species-group.

Astyanacinus was regarded as a valid taxon by D'Agosta (2011). However, the phylogenetic analysis leading to that conclusion considered only four species of Astyanax and, most importantly, it did not include any species of the Astyanax bimaculatus-group. As demonstrated by Mirande (2009, 2010), Astyanax comprises numerous clades. Demonstration of monophyly of Astyanacinus is not sufficient to validate the genus, unless it can be demonstrated that the group is not nested withing a subgroup of Astyanax. Additionally, molecular analyses (Calcagnotto et al. 2005; Ornelas-García et al. 2008) do not corroborate the hypothesis of a monophyly of Astyanacinus as proposed by D'Agosta (2011). 
Our recognition of the orthodus species-group as a member of the Astyanax clade must be regarded as provisional until a comprehensive phylogenetic analysis of Astyanax becomes available. Our observations, however, provide a working hypothesis for nested groups that can contribute to a more comprehensive phylogenetic study of Astyanax. Based on this work, we find that Astyanacinus species are a clade within Astyanax and so Astyanacinus is a junior synonym of Astyanax.

\section{Acknowledgements}

We thank the Universidad del Quindío, Armenia, Colombia (UQ) for financial and logistic support for our research (project 594 to C. Román-Valencia, R.I. Ruiz-C. and D.C. Taphorn) and the Facultad de Ciências Básicas (UQ) for research travel funds to D.C. Taphorn. (June-July 2013 and 2014). The research of P.A. Buckup received financial support from CNPq (307610/2013-6, 564940/2010-0, 476822/2012-2), FAPERJ (E-26/111.404/2012) and CAPES. The following persons provided loans of material under their care: Soraya Barrera and Jaime Sarmiento, Francisco A. Villa, Jaime Aguirre C., German Parra, Paulo A. Buckup, Romain Causse, Mike Retzer and B. Chernoff, Georges Lenglet, Ramiro Barriga, Mabel Maldonado, Jon Armbruster, Claudia A. Medina, Laurence M. Page, Luz Fernanda Jimenez, Barbara Brown, Margaret Lucena and Carlos A. Lucena, Amalia Miquelarena, Marcos Mirande and Ana M. Frias F. Photographs of Astyanax moorii comb. nov. were produced by Victor de Brito. Cristian RománPalacios drafted the distribution map (Fig. 4), Claudio Oliveira and two anonymous reviewers provided comments and recommendations for a previous version of this paper.

\section{References}

Angulo A., Garita-Alvarado C.A., Bussing W.A. \& López M.I. 2013. Annotated checklist of the freshwater fishes of continental and insular Costa Rica: additions and nomenclatural revisions. Check List 9: 987-1019. https://doi.org/10.15560/9.5.987

Bertaco V.A. \& Lucena C.A.S. 2010. Redescription of Astyanax obscurus (Hensel, 1870) and A. laticeps (Cope, 1894) (Teleostei: Characidae): two valid freshwater species originally described from rivers of southern Brazil. Neotropical Ichthyology 8: 7-20. Available from http://www.scielo.br/pdf/ni/v8n1/ v08n1a02.pdf [accessed 6 Dec. 2017].

Bertaco V.A., Carvalho F.R. \& Jerep F.C. 2010. Astyanax goyanensis (Miranda-Ribeiro, 1944), new combination and Astyanax courensis, new species (Ostariophysi: Characiformes): two Characidae from the upper rio Tocantins Basin, central Brazil. Neotropical Ichthyology 8: 265-275. https://doi.org/10.1590/S1679-62252010000200004

Boulenger G.A. 1892. On some new or little-known fishes obtained by Dr. J. W. Evans and Mr. Spencer Moore during their recent expedition to the Province of Matto Grosso, Brazil. Annals and Magazine of Natural History (Series 6) 10 (55) (art. 2): 9-12.

Calcagnotto D., Schaefer S.A. \& DeSalle R. 2005. Relationships among characiform fishes inferred from analysis of nuclear and mitochondrial gene sequences. Molecular Phylogenetics and Evolution 36: 135-153. https://doi.org/10.1016/j.ympev.2005.01.004

D’Agosta F.C.A. 2011. Taxonomia e relacoes filogenéticas do genero Astyanacinus Eigenmann 1907 (Characiformes: Characidae). Unpublished M.Sc. thesis. Universidade de São Paulo, Brazil.

Eigenmann C. 1910. Catalogue of freshwater fishes of tropical and South temperate America. In: Scott W.B. (ed.) Reports of the Princeton University Expedition to Patagonia, 1896-1899. Volume 3 Zoölogy: 375-511, Indiana University, Bloomington, USA. https://doi.org/10.5962/bhl.title.2097

Eigenmann C.H. 1921. The American Characidae. Memoirs of the Museum of Comparative Zoology 43: 97. 
RUIZ-C. R.I. et al., Revision of the Astyanax orthodus species-group

Eigenmann C.H. 1927. The American Characidae. Memoirs of the Museum of Comparative Zoology 43: $311-428$.

Eigenmann C.H. \& Ogle F. 1907. An annotated list of characin fishes in the United States National Museum and the Museum of Indiana University, with descriptions of new species. Proceedings of the United States National Museum 33: 1-36. https://doi.org/10.5479/si.00963801.33-1556.1

Fink W.L. \& Weitzman S.H. 1974. The so-called Cheirodontin fishes of Central America with descriptions of two new species (Pisces: Characidae). Smithsonian Contributions to Zoology 172: 1-46. https://doi.org/10.5479/si.00810282.172

Garutti V. \& Britski H.A. 1997. Descrição de uma espécie nova de Astyanax (Teleostei, Characidae), com mancha umeral horizontalmente ovalada, da bacia do rio Guaporé, Amazônia. Papéis Avulsos de Zoologia Museu de Zoologia da Universidade de São Paulo 40: 217-229.

Garutti V. \& Langeani F. 2009. Redescription of Astyanax goyacensis Eigenmann, 1908 (Ostariophysi: Characiformes: Characidae). Neotropical Ichthyology 7: 371-376.

https://doi.org/10.1590/S1679-62252009000300003

International Comission on Zoological Nomenclature. 1999. International Code of Zoological Nomenclature. 4. ed. International Trust for Zoological Nomenclature, London.

Javonillo R., Malabarba L.R., Weitzman S.H. \& Burns J.R. 2010. Relationships among major lineages of characid fishes (Teleostei: Ostariophysi: Characiformes), based on molecular sequence data. Molecular Phylogenetics and Evolution 54: 498-511. https://doi.org/10.1016/j.ympev.2009.08.026

Kavalco K.F., Oliveira Brandão K. de, Pazza R. \& Almeida-Toledo L.F. 2009. Astyanax hastatus Myers, 1928 (Teleostei, Characidae): A new species complex within the genus Astyanax? Genetics and Molecular Biology 32: 477-483. https://doi.org/10.1590/S1415-47572009005000055

Langerhans R.B., Layman C.A., Langerhans A.K \& Dewitt T.J. 2003. Habitat-associated morphological divergence in two Neotropical fish species. Biological Journal of the Linnean Society 80: 689-698. https://doi.org/10.1111/j.1095-8312.2003.00266.x

Marinho M.M.F., Camalier P. \& Birindelli J.L.O. 2015. Redescription of Astyanax guianensis Eigenmann 1909 (Characiformes: Characidae), a poorly known and widespread fish from the Amazon, Orinoco and Guiana Shield drainages. Zootaxa 3931: 568-578. https://doi.org/10.11646/zootaxa.3931.4.6

Martin R.A. \& Pfennig D.W. 2009. Disruptive selection in natural populations: the roles of ecological specialization and resource competition. The American Naturalist 174: 268-281. https://doi.org/10.1086/600090

Mirande J.M. 2009. Weighted parsimomy phylogeny of the family Characidae (Teleostei: Characiformes). Cladistics 25: 1-39. https://doi.org/10.1111/j.1096-0031.2009.00262.x

Mirande J.M. 2010. Phylogeny of the family Characidae (Teleostei: Characiformes): from characters to taxonomy. Neotropical Ichthyology 8: 385-568. https://doi.org/10.1590/S1679-62252010000300001

Mirande J.M., Aguilera G. \& Azpelicueta M.M. 2011. A threatened new species of Oligosarcus and its phylogenetic relationships, with comments on Astyanacinus (Teleostei: Characidae). Zootaxa 2994: $1-20$.

Mirande J.M., Jerep F.C. \& Vanegas-Rios J.A. 2013. Phylogenetic relationships of the enigmatic Carlastyanax aurocaudatus (Eigenmann) with remarks on the phylogeny of the Stevardiinae (Teleostei: Characidae). Neotropical Ichthyology 11: 747-766. https://doi.org/10.1590/S1679-62252013000400003

Myers G.S. 1942. Studies on South American fresh-waters fishes. Stanford Ichthyological Bulletin 2: $89-135$. 
Oliveira C., Avelino G.S., Abe K.T., Mariguela T.C., Benine R.C., Ortí G., Vari R.A. \& Castro R.M.C. 2011. Phylogenetic relationships within the speciose family Characidae (Teleostei: Ostariophysi: Characiformes) based on multilocus analysis and extensive ingroup sampling. BMC Evolutionary Biology 11: 275. https://doi.org/10.1186/1471-2148-11-275

Ornelas-García C.P., Domínguez-Domínguez O. \& Doadrio I. 2008. Evolutionary history of the fish genus Astyanax Baird \& Girard (1854) (Actinopterygii, Characidae) in Mesoamerica reveals multiple morphological homoplasies. BMC Evolutionary Biology 8 (340). https://doi.org/10.1186/1471-2148-8-340

Pearson N.E. 1924. The Fishes of the Eastern Slope of the Andes. Indiana University Studies 11, Indiana University, Bloomington, USA.

Román-Valencia C. 2003. Sistemática de las especies Colombianas de Bryconamericus (Characiformes, Characidae). Dahlia 6: 17-58.

Román-Valencia C., Ruiz-C.R., Taphorn D.C., Jiménez-Prado P. \& García-Alzate C.A. 2015. A new species of Bryconamericus (Characiformes, Stevardiinae, Characidae) from the Pacific coast of northwestern Ecuador, South America. Animal Biodiversity and Conservation 38.2: 241-252. Available from http://abc.museucienciesjournals.cat/files/ABC_38-2_pp_241-252.pdf [accessed 20 Oct. 2017].

Ruiz-C.R.I. \& Cipriani R. 2007. Morfometría geométrica de Astyanax siapae (Pisces, Characidae). Dahlia 9: 63-75.

Ruiz-C.R.I., Román-Valencia C., Herrera B. Peláez O. \& Ermakova-A.A. 2011. Variación morfológica de las especies de Astyanax subgénero Zygogaster (Pisces, Characiformes, Characidae). Animal Biodiversity and Conservation 34: 47-66. Available from

http://abc.museucienciesjournals.cat/wp-content/blogs.dir/2/files/ABC-34-1-pp-47-66.pdf [accessed 20 Oct. 2017].

Sabaj-Perez M.H. 2016. Standard Symbolic Codes for Institutional Resource Collections in Herpetology and Ichthyology: an online reference, version 6.5 (16 Aug. 2016).

Available from http://www.asih.org/ [accessed 20 Oct. 2017].

Schluter D. 2000. The Ecology of Adaptive Radiation. Oxford University Press, Oxford.

Schmitter-Soto J.J. 2016. A phylogeny of Astyanax (Characiformes: Characidae) in Central and North America. Zootaxa 4109: 101-130. https://doi.org/10.11646/zootaxa.4109.2.1

Schneider C.A., Rasband W.S. \& Eliceiri K.W. 2012. NIH Image to ImageJ: 25 years of image analysis. Nature Methods 9: 671-675. https://doi.org/10.1038/nmeth.2089

Taylor W.R. \& Van Dyke G.C. 1985. Revised procedures for staining and clearing small fishes and other vertebrates for bone and cartilage study. Cybium 9: 107-119.

Torres-Mejía M., Hernández E. \& Senechal V. 2012. A new species of Astyanacinus (Characiformes: Characidae) from the Río Magdalena System, Colombia. Copeia 2012: 501-506.

https://doi.org/10.1643/CI-10-160

Van Der Laan R., Eschmeyer W. \& Fricke R. 2014. Family-group names of recent fishes. Zootaxa 3882: 1-230. https://doi.org/10.11646/zootaxa.3882.1.1

Vari R. \& Castro R.M.C. 2007. New species of Astyanax (Ostariophysi, Characiformes, Characidae) from the Upper Rio Paraná System, Brazil. Copeia 2007 (1): 150-162.

https://doi.org/10.1643/0045-8511(2007)7\%5B150:NSOAOC\%5D2.0.CO;2

Vari R.A. \& Siebert D.J. 1990. A new unusually sexually dimorphic species of Bryconamericus (Pisces: Ostariophysi: Characidae) from the Peruvian Amazon. Proceedings of the Biology Society of Washington 103: 516-524. 
Weitzman S.H. 1962. The osteology of Brycon meeki, a generalized characid fish, with an osteological definition of the family. Stanford Ichthyological Bulletin 8: 1-77.

Wilkens H. \& Strecker U. 2003. Convergent evolution of the cavefish Astyanax (Characidae, Teleostei): genetic evidence from reduced eye-size and pigmentation. Journal of Linnean Society 80: 545-554. https://doi.org/10.1111/j.1095-8312.2003.00230.x

Zarske A. \& Géry J. 1999. Astyanax villwocki sp. nov. - a new characid fish from the upper Amazon Basin of Peru and Bolivia (Teleostei, Characiformes, Characidae). Mitteilungen aus dem Hamburgischen Zoologischen Museum und Institut 96: 199-206.

Manuscript received: 5 October 2016

Manuscript accepted: 15 March 2017

Published on: 8 February 2018

Topic editor: Rudy Jocqué

Desk editor: Kristiaan Hoedemakers

Printed versions of all papers are also deposited in the libraries of the institutes that are members of the EJT consortium: Muséum national d'Histoire naturelle, Paris, France; Botanic Garden Meise, Belgium; Royal Museum for Central Africa, Tervuren, Belgium; Natural History Museum, London, United Kingdom; Royal Belgian Institute of Natural Sciences, Brussels, Belgium; Natural History Museum of Denmark, Copenhagen, Denmark; Naturalis Biodiversity Center, Leiden, the Netherlands; Museo Nacional de Ciencias Naturales-CSIC, Madrid, Spain; Real Jardín Botánico de Madrid CSIC, Spain. 


\section{Appendix}

\section{Comparative material examined}

Astyanax chico Casciotta \& Almirón, 2004: ARGENTINA: 3 specimens (56.6-70.5 mm SL), 1 specimen C\&S (68.3 mm SL), Salta, Campo Largo, "arroyo" or "quebrada" tributary of the Itau River (IUQ 1646).

Astyanax endy Mirande, Aguilera \& Azpelicueta, 2006: ARGENTINA: 9 specimens (45.2-61.1 mm SL), Salta, Orán, Bermejo River Basin, Blanco River at El Oculto (IUQ 1636).

Astyanax elachylepis Bertaco \& Lucinda, 2005: BRAZIL: 1 specimen $(88.9 \mathrm{~mm}), 1$ specimen C\&S (80.4 mm SL), Maranhão River, Goiás (MCP 16054).

Astyanax fasciatus (Cuvier, 1819): BRAZIL: 5 specimens (84.9-101.4 mm SL), Rio de Janeiro State, Municipality of Rio Claro, Ribeirão das Lages Hydrolectric damn, at Da Prata River branch (MNRJ 20716).

Astyanax festae (Boulenger, 1898): ECUADOR: 2 specimens (44.6- $44.8 \mathrm{~mm}$ SL), 2 specimens C\&S (45.5-46.8 mm SL), Manabi province, Pacific Basin, Puerto Viejo (AMNH 5367). - PERU: 30 specimens (36.8-50.9 mm SL), Tumbes department, Zarumilla province, Zarumilla Rive (MUSM 1981); 5 specimens (39.4-43.1 mm SL), Tumbes, Tumbes River (MUSM 3291); 53 specimens (25.4-54 mm SL), Tumbes River, Piojo channel bridge (MUSM 3395); 4 specimens (43.3-44.8 mm SL), Tumbes, Zarumilla, Zarumilla River La Pampa (MUSM 5764).

Astyanax integer Myers, 1930: COLOMBIA: 1 specimen (59.7 mm SL), Tauramena, Casanare (IAvHP 3243); 2 specimens (90.9-109.4 mm SL), Orinoco River, Meta (IAvHP 3516); 5 specimens (49.2-66.1 mm SL), Urichare Creek, inspección Puerto Caldas, Granada, Meta, Orinoco River Basin (IAvHP 5169); 12 specimens (54.1-64.7 mm SL), Cravo Sur River, Yopal, Casanare (IAvHP ex 7912); 1 specimen (70.6 mm SL), Urichare Creek, inspección Puerto Caldas, Granada, Meta, Orinoco River Basin (IAvHP 11253). - VENEZUELA: 5 specimens (45.9-58.6 mm SL), quebrada Guatiré, tributary Orinoco River, Anzoategui (MBUCV 33123); 1 specimen (53.1 mm SL), creek tributary Apure River, Portuguesa state (MCNG 48480); 5 specimens (51.2-57.2 mm SL), Rabipelado Creek, tributary Apure River, Portuguesa (MCNG 52153).

Astyanax lineatus (Perugia, 1891): ARGENTINA: 3 specimens (55.5-60.2 mm SL), Agua Caliente Creek,

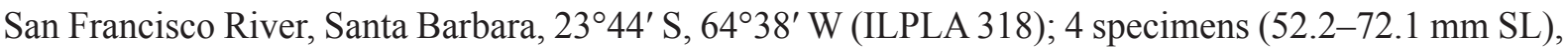
Saladillo River, Guames, Salata, $24^{\circ} 40^{\prime}$ S, $65^{\circ} 03^{\prime}$ W (ILPLA 1423); 3 specimens (47.6-62.5), de las Conchas River RN 34 y 9.5 km N of Metán (loc. 51) Juramento River Basin, $25^{\circ} 28^{\prime} \mathrm{S}, 64^{\circ} 57^{\prime} \mathrm{W}$, Salta (ILPLA 1446); 2 specimens (77.6-80.3 mm SL), 3 specimens C\&S (46.6- $59.4 \mathrm{~mm} \mathrm{SL),} \mathrm{Bermejo} \mathrm{River}$ sobre la ruta Prov. 19, Oran, Salta, Paraná River (IUQ 1647). - BOLIVIA: 3 specimens (46.7-94.2 mm SL), San Bernardo River en el camino Yucumo, Rurrenabaque, Beni (CBF 2606); 12 specimens (57.4$89.1 \mathrm{~mm}$ SL), Ixiamas, at $15 \mathrm{~km} \mathrm{~W}$ of Ixiamascamino al alto Madidi, La Paz (CBF 2810); 4 specimens (40.8-70.4 mm SL), National Park at management area Amboro, Ichilo, Santa Cruz (CBF 7185); 6 specimens (45.8-50.8 mm SL) (CBF 7448); 1 specimen (50.5 mm SL), Santa Cruz, Quise River, San Pablo drainage, Santa Cruz (UF 167447); 1 specimen (73,8 mm SL), Piray River, Mamoré drainage (UF 167471); 7 specimens (50.9-67.6 mm SL), Heredia River, Parapeti, Chuquisaca, 1948'11.3724" S,

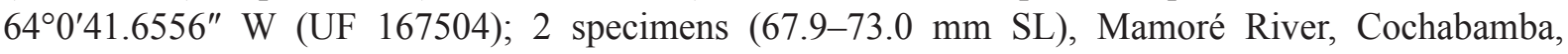
$18^{\circ} 7^{\prime} 48.8532^{\prime \prime} \mathrm{S}, 64^{\circ} 53^{\prime} 41.9504^{\prime \prime} \mathrm{W}$ (UF 167515); 20 specimens (52.7-85.6 mm SL), Tacuaral Creek, Tohomonoco, Alto Beni River, Madeira, 1545'46.33" S, 6744'84.66" W (UMSS 8928); 20 specimens (56.4-86.1 mm SL), Tacuaral Creek, Tohomonoco, Alto Beni River, Madeira (UMSS 10012). - PERU: 4 specimens (58.4-75.3 mm SL), Tambopata River, Madre de Dios department (MUSM 11301). 
RUIZ-C. R.I. et al., Revision of the Astyanax orthodus species-group

Astyanax maximus (Steindachner, 1876): COLOMBIA: 2 specimens (104.3-105.8 mm SL), Guayuyaco River, in the village Miraflor, Cauca department, on the road from Villa Garzoa to San Jose de Fragua (IUQ 616); 2 specimens (98.9-115.9 mm SL), Inchiyaco River, on the road from villa Garzon to San Jose de Fragua (IUQ 971); 6 specimens (59.8-130.3 mm SL), 1 specimen C\&S (53.2 mm SL), Tambor River, on the road from Villa Garzón to San José de Fragua, Caquetá (IUQ 972); 2 specimens (86.3$113.9 \mathrm{~mm}$ SL), Nabueno Creek sector of Miraflor Cauca, on the road from villa Garzon to San Jose del Fragua (IUQ 1067); 1 specimen (112.3 mm SL), La Vio Creek on the road via Florencia to La Montañita, Vereda Citarca, Caqueta department (IUQ 1426); 2 specimens (114.6-140.3 mm SL), Orteguaza River, Casqueta (IUQ 1598).

Astyanax mexicanus (De Filippi, 1853): USA: 8 specimens (47.4-59.7 mm SL), 2 specimens C\&S (53.0-63.7 mm SL), Devils River, Texas (INHS 80766). - MEXICO: 2 specimens (31.1-35.6 mm SL), Tonalá River, San José, Tancuchapa, Choapas (UNAM-P 12235).

Astyanax ruberrimus (De Filippi, 1853): COLOMBIA: 5 specimens (62.5-75.6 mm SL), mouth of Yamunde River, Telembi River, $1 \mathrm{~km}$ below Barbacoas, Nariño department (IUQ 253); 2 specimens (62.7-74.6 mm SL), Patía River, refugio UPESIA, Patía municipality, Cauca department, Pacifico Basin (IUQ 1237).

Astyanax viejita (Valenciennes, 1850): VENEZUELA: 3 specimens (45.8-59.2 mm SL), Cachirí River, Lago de Maracaibo (MBUCV 18265).

Astyanax abramis (Jenyns, 1842): ARGENTINA: 1 specimen (85.6 mm SL), El Pescado Creek, Anta department, Salta, $24^{\circ} 42^{\prime} \mathrm{S}, 6^{\circ} 38^{\prime} \mathrm{W}$ (ILPLA 1); 1 specimen (90.5 mm SL), 1 specimen C\&S $(89.0 \mathrm{~mm}$ SL), Laguna La Mira, Santa Fe (ILPLA 359); 1 specimen (93.2 mm SL), Paraná River Basin, Corrientes (ILPLA 874); 1 specimen (93.9 mm SL), 1 specimen C\&S (81.6 mm SL), Corrientes province (MLP 1630); 1 specimen (105.5 mm SL), to $1 \mathrm{~km}$ from mouth of the Iguazu River, Misiones province (MLP 9427).

Astyanax altiparanae Garutti \& Britski, 2000: BRAZIL: 3 specimens (105.0-110.6 mm SL), 1 specimen C\&S (101.3 mm SL), Piracicaba River, São Paulo, 2243'19" S, 47³9'21" W (MCP 27862).

Astyanax atratoensis Eigenmann, 1907: COLOMBIA: 21 specimens (55.0-117.9 mm SL), Atrato River (IAvHP 7140); 2 specimens (78.4-82.3 mm SL), Turbo municipality, Antioquia department, Atrato River Basin, Muerto Creek, última Ciénaga, El Cuarenta locality (IAvHP 7187); 3 specimens (71.2-91.8 mm SL), Antioquia department, Turbo, Atrato River Basin, ciénaga Tumarado, El Cuarenta locality (IAvHP 7206); 2 specimens (85.7-88.2 mm SL), 2 specimens C\&S (83.6-84.9 mm SL), Chocó department, Quibdó, Atrato River on Malecón de Quibdó (IUQ 84); 3 specimens (90.2-110.7 mm SL), Chocó, Atrato River Basin, Negro River, El Ganado locality (IUQ 696); 2 specimens (68.9-76.0 mm SL), 1 specimen C\&S (64.8 mm SL), Chocó department, Atrato River Basin Negro River, ciénaga de Achuara (IUQ 745).

Astyanax bimaculatus (Linnaeus, 1758): ESSEQUIBO-GUYANA: 1 specimen (44.9 mm SL), 1 specimen C\&S (68.0 mm SL), Amacuro River, Santa Rosa (AMNH 14434); 1 specimen (52.5 mm SL), Yaraquita River (AMNH 14549); 1 specimen (27.3 mm SL), Georgetown, Demerara (AMNH 221021).

Astyanax sp. 1: VENEZUELA (Bolívar state, Caroni River drainage): 7 specimens (25.5-59.1 mm SL), 3 specimens C\&S (36.8-47.9 mm SL), originating of the Claro River in Fundo el Barco, entering by green house from the road Puerto Ordaz, Ordaz-Ciudad Piar, 760'50" N, 633ㄴ'58" W (AUM 55081); 6 specimens (53.1-62.4 mm SL), little river near the beach Ride below the dam, $7^{\circ} 82^{\prime} 22^{\prime \prime} \mathrm{N}, 63^{\circ} 98^{\prime} 75^{\prime \prime} \mathrm{W}$ (MCNG 18212); 3 specimens (44.0-45.0 mm SL), Tocoma River E of San Juan de Tocoma, $7^{\circ} 72^{\prime} 92^{\prime \prime}$ N, 
$63^{\circ} 15^{\prime} 83^{\prime \prime} \mathrm{W}$ (MCNG 18234); 4 specimens (36.7-45.4 mm SL), Claro River under the bridge on the road to Gurí, 7 $91^{\prime} 67^{\prime \prime} \mathrm{N}, 63^{\circ} 08^{\prime} 89^{\prime \prime} \mathrm{W}$ (MCNG 18252); 8 specimens (47.5-69.4 mm SL), Tocomita River $5 \mathrm{~km}$ northward from the highway access to the Guri dam Gurí, $7^{\circ} 80^{\prime} 69^{\prime \prime} \mathrm{N}, 63^{\circ} 09^{\prime} 86^{\prime \prime} \mathrm{W}$ (MCNG 18283); 7 specimens (41.8-51.4 mm SL), Tocoma River, lower stretch, at an access through the railway route, below high voltage cables, $7^{\circ} 84^{\prime} 44^{\prime \prime} \mathrm{N}, 63^{\circ} 08^{\prime} 50^{\prime \prime} \mathrm{W}$ (MCNG 18331); 2 specimens (33.7-42.9 mm SL), Claro River E of Los Tanques, $7^{\circ} 92^{\prime} 22^{\prime \prime} \mathrm{N}, 6^{\circ} 10^{\prime} 14^{\prime \prime} \mathrm{W}$ (MCNG 18387); 8 specimens (44.5-58.5 mm SL), Tocomita River isolated pool $2 \mathrm{~km}$ above RC_7 (MCNG 18461); 2 specimens (68.3-72.7 mm SL), Tocoma River, stream ("morichal”) near Mereycito, $7^{\circ} 47^{\prime} 08^{\prime \prime} \mathrm{N}, 63^{\circ} 24^{\prime} 17^{\prime \prime} \mathrm{W}$ (MCNG 18517);

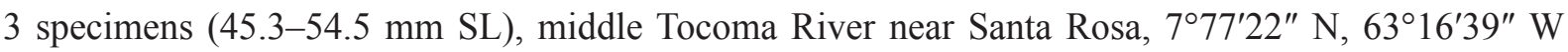
(MCNG 18541); 5 specimens (39.9-64.6 mm SL), Claro River middle Claro River, at aqueduct crossing,

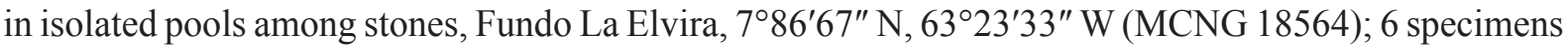
(43.9-55.4 mm SL), 1 specimen C\&S (38 mm SL), El Muerto Creek near Hato Mata Linda, $7^{\circ} 79^{\prime} 44^{\prime \prime}$ N, 632ㅇ'61" W (MCNG 18574); 10 specimens (45.7-53.0 mm SL), Mojacasabe Creek $800 \mathrm{~m}$ above its mouth in the Tocoma River, $7^{\circ} 64^{\prime} 31^{\prime \prime} \mathrm{N}, 63^{\circ} 15^{\prime} 83^{\prime \prime} \mathrm{W}$ (MCNG 18589); 9 specimens (23.5-48.4 mm SL), Santa Isabel River ((headwaters), Fundo El Chubasco, entering through Casa Verde from highway Puerto Ordaz-Ciudad Piar, 764'17" N, 6335'42" W (MCNG 18607); 1 specimen (50.8 mm SL), Creek tributary to the Uairén River, 4${ }^{\circ} 57^{\prime} 67^{\prime \prime} \mathrm{N}, 61^{\circ} 25^{\prime} 19^{\prime \prime} \mathrm{W}$ (MCNG 44892); 1 specimen (52.0 mm SL), Uruaní River between km 247-248 on the road to Luepa, $5^{\circ} 08^{\prime} 00^{\prime \prime} \mathrm{N}, 61^{\circ} 09^{\prime} 72^{\prime \prime} \mathrm{W}$ (MCNG 44936); 1 specimen ( $70.8 \mathrm{~mm} \mathrm{SL}$ ), Creek tributary to the Tocomita River, east of Guri airport, in pool at culvert (MCNG 56440); 5 specimens (39.7-63.4 mm SL), Agua Fría Creek, a tributary to the Paragua River (MBUCV 4130).

Astyanax sp. 2: VENEZUELA (Bolívar state, Cuyuní River drainage): 5 specimens (25.9-89.2 mm SL), 2 specimens C\&S (45.7-67.8 mm SL), Parapapoy River, 2 km upstream from [air?]strip (AUM 55083); 2 specimens (59.8-65.0 mm SL), Clara Creek, below the point near the island Anacoco, $6^{\circ} 460^{\prime} 0^{\prime \prime} \mathrm{N}$, $61^{\circ} 12^{\prime} 00^{\prime \prime} \mathrm{W}$ (MCNG 16437); 3 specimens (40.7-69.1 mm SL), Parapapoy River, 2 km upstream from [air?]strip (MCNG 28262); 2 specimens (37.1-58.0 mm SL), Creek in the marginal forest of Parapapoy River (MCNG 28375); 4 specimens (47.2-65.9 mm SL), tributary of Yuruari River, $3 \mathrm{~km} \mathrm{~W}$ of Guasipati, road to La Pastora, 747'14" N, 6191'69" W (MCNG 29347); 3 specimens (70.0-74.0 mm $\mathrm{SL}$ ), in pool isolated from main river course, at Paruruvaca rapids ("raudal") Paruruvaca (MBUCV 10145); 4 specimens (51.1-63.2 mm SL), Creek at km 72 on the road to El Dorado-Santa Elena de Uairen (MBUCV 26194); 4 specimens (34.9-47.9 mm SL), roadside lake at Tumeremo-Anacoco road Tumeremo-Anacoco (MBUCV 26341); 3 specimens (72.1-83.3 mm SL), stream ("morichal) in the area near a San Antonio, El Manteco-El Yagual road (MBUCV 26349); 4 specimens (58.6-66.0 mm SL), Corumito Creek, tributary of Botanamo River, on road Tumeremo-Bochinche (MBUCV 26409); 2 specimens (40.2-45.4 mm SL), Corumito Creek, tributary of Botanamo River, on road TumeremoBochinche (MBUCV 26413); 1 specimen (71.7 mm SL), Tapón de Boterano, lake on TumeremoBochincero road, 7²5'21" N, 61 ${ }^{\circ} 14^{\prime} 29^{\prime \prime} \mathrm{W}$ (MBUCV 28556); 6 specimens (26.1-89.1 mm SL), 2 specimens C\&S (35.8-56.9 mm SL), Parapapoy River, $2 \mathrm{~km}$ river uptrail from [road]strip, Dept Roscio (MBUCV 28254).

Astyanax sp. 3: PERU: 1 specimen (53.6 mm SL), Atalaya, Sepahua, Amazon River Basin, Urubamba River, Piquinia Creek, Ucayali (MUSM 13024); 3 specimens (75.0-76.9 mm SL), 1 specimen C\&S (72.2 mm SL), Madre de Dios, Tambopata, Amazon River Basin, Palmichal (MUSM 16514); 10 specimens (25.7-73.7 mm SL), Cuzco, Quispicamchi, Camanti, San Lorenzo, Araza River (MUSM 26748); 1 specimen (71.3 mm SL), Satipo, Mashir, Capirosantiari Creek, Tambo River Basin, Junin (MUSM 37885). 
RUIZ-C. R.I. et al., Revision of the Astyanax orthodus species-group

Astyanax sp. 4: VENEZUELA: 3 specimens (40.3-86.7 mm SL), 1 specimen C\&S (97.8 mm SL), Neveri River, Canal, road 2 a little to the N of Cariaco, Sucre (MCNG 19415); 2 specimens (40.3-86.7 mm SL), 1 specimen C\&S (65.7 mm SL), Neveri River, Anzoategui (MCNG 48719).

Astyanax sp. 5: VENEZUELA (Miranda): 4 specimens (6.9-84.5 mm SL), 2 specimens C\&S (47.666.5 mm SL), Cuira River. Sistema del Tuy (MBUCV 3726); 3 specimens (48.5-64.6 mm SL), Rebollero Creek, Tuy River Basin (MBUCV 5004); 2 specimens (79.3-85.1 mm SL), point near Araguita al Sur (MCNG 14300); 4 specimens (46.4-72.7 mm SL), Guare River de Tácata, aprox. 5 km above Tácata (MCNG 14092); 1 specimen (56.7 mm SL), El Lindero Creek, road 9, at the point just SE of Cupo (MCNG 17167); 23 specimens (24.8-52.1 mm SL), Merecure River (MCNG 28036).

Astyanax sp. 6: VENEZUELA: 3 specimens (55.1-85.3 mm SL), 2 specimens C\&S (33.7-60.7 mm SL), Las Peñitas River en Vigirima, NE of Valencia Lake, Carabobo (MCNG 24646).

Astyanax sp. 7: COLOMBIA: 2 specimens (58.9-76.5 mm SL), Cravo Sur River, Yopal Casanare (IAvHP 7912); 2 specimens (63.2-65.4 mm SL), Cravo Sur River, Yopal, Casanare (IAvHP 9699).

Astyanax brevoortii (Gill, 1858): TRINIDAD: 15 specimens (71.7-98.7 mm SL), Saint Andrew Country (AMNH 215258); 5 specimens (74.3-97.5 mm SL), Arima (AMNH 215269); 1 specimen (98.1 mm SL), Guanapo River (MCNG 8197); 5 specimens (26.3-52.7 mm SL), Cedros Creek (MCNG 8228); 6 specimens (3.4-4.9 mm SL), Matura (MCNG 8241); 4 specimens (37.6-72.9 mm SL), 2 specimens C\&S (51.3-71.6 mm SL), Matura (MCNG 8250). - CARIBE-VENEZUELA: 10 specimens (41.4$81.5 \mathrm{~mm} \mathrm{SL}$ ), Arenas River, between the villages Quebrada-Cumanacoa, on the bridge of road \# 1 , tributary San Juan River, $8^{\circ} 15^{\prime} 00^{\prime \prime}$ N, $73^{\circ} 23.75^{\prime}$ W (AUM 55082); 1 specimen (47.3 mm SL), Balneario Poza de Azufre, S of the border of Estado and N of Caripito, tributary San Juan River, $10^{\circ} 20^{\prime} 00^{\prime \prime} \mathrm{N}$, 6308'33" W, Sucre (MCNG 11273); 7 specimens (27.4-60.3 mm SL), Dept Valdez, La Toma River to $6 \mathrm{~km} \mathrm{~N}$ from road 9 to $4 \mathrm{~km} \mathrm{~W}$ of Guiria, tributary San Juan River, $10^{\circ} 50^{\prime} \mathrm{N}, 62^{\circ} 30 \mathrm{~W}$, Sucre (MCNG 19692); 2 specimens (58.7-74.9 mm SL), San Miguel River, tributary San Juan River, near La Palencia, $8^{\circ} 52.00^{\prime} \mathrm{N}, 63^{\circ} 12.00^{\prime} \mathrm{W}$, Sucre (MCNG 43484); 3 specimens (81.3-91.6 mm SL), Juan Antonio Creek,

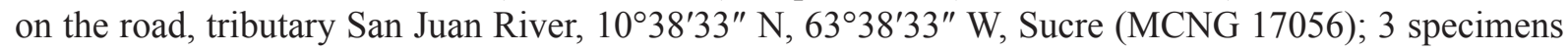
(78.0-100.1mm SL), Parque Nacional Península de Paria, sector Los Mangos,Bautista River, tributary of San Juan River, 10 $3^{\circ} 3^{\prime} \mathrm{N}, 63^{\circ} 5^{\prime} \mathrm{W}$, Sucre (MCNG 29747); 8 specimens (51.3-90.6 mm SL), 2 specimens C\&S $(60,7-65,9 \mathrm{~mm} \mathrm{SL})$, creek $20 \mathrm{~km}$ E of El Pilar, Golfo de Paria, $10^{\circ} 33^{\prime} \mathrm{N}, 63^{\circ} 5^{\prime} \mathrm{W}$, Sucre (MCNG 17036); 4 specimens (25.6-70.4 mm SL), creek, Golfo de Paria, $7 \mathrm{~km} \mathrm{~S}$ of El Pilar, road to Guariquén, $10^{\circ} 33^{\prime} \mathrm{N}, 63^{\circ} 5^{\prime} \mathrm{W}$, Sucre (MCNG 11208); 5 specimens (61.0-86.0 mm SL), Golfo de Paria, Pilar River, near the village El Pilar, near drainage into Turuepano River, $10^{\circ} 53^{\prime} 33^{\prime \prime} \mathrm{N}, 63^{\circ} 13^{\prime} 33^{\prime \prime} \mathrm{W}$, Sucre (MCNG 17028); 2 specimens (43.6-67.8 mm SL), 3 specimens C\&S (53,2-62,4 mm SL), dam of Highway 9 at $10 \mathrm{~km} \mathrm{~W}$ of Barcelona, $9^{\circ} 20.50^{\prime} \mathrm{N}, 6^{\circ} 9.50^{\prime} \mathrm{W}$, Anzoátegui (MCNG 19271); 14 specimens (44.6-76 mm SL), Cariaco River, on the road, W of Cariaco, $10^{\circ} 0.67^{\prime} \mathrm{N}, 63^{\circ} 18.00^{\prime} \mathrm{W}$, Sucre (MCNG 17014); 7 specimens (58.5-95.2 mm SL), Chiquito Stream ("quebrada", tributary to Caripe River, near Escuela, Granja Caripe River, Caripito, tributary of San Juan River, Monagas (MBUCV 9731); 2 specimens (43.2-67.1 mm SL), 2 specimens C\&S (54,6-57,9 mm SL), Acequia de Leandro, S of Guaraunos, Turuepano, Sucre (MBUCV 12261); 6 specimens (41.4-59.6 mm SL), Amara River, under the bridge on the road Maturín-Temblador, Monagas (MBUCV 12322); 2 specimens (78.9-89.3 mm SL), 2 specimens C\&S (79.9-86.2 mm SL), Caripe River, on the las Chorreras, near Caripito, tributary of San Juan River, Monagas (MBUCV 12409); 3 specimens (49.6-71.5 mm SL), Bohordal River, near the village, Medio River, N of Bohordal (bridge on the road), Turuepano, Sucre (MBUCV 20235). ORINOCO-VENEZUELA: 3 specimens (29.6-56.3 mm SL), Guarico River at Balneario Los Mangos, Barbacoas Los Mangos, $9^{\circ} 38.75^{\prime} \mathrm{N}, 66^{\circ} 54.05^{\prime} \mathrm{W}$, Aragua (MCNG 29097); 3 specimens (63,3-75,3 mm SL), Modulo "Fernando Corrales" de la Unellez, western dike, $7^{\circ} 25.33^{\prime}$ N, $69^{\circ} 35.67^{\prime}$ W, Apure (MCNG 
2219); 3 specimens (31,1-46,3 mm SL), Catis River on Hato El Morón, SE of El Tigre road to Cd. Bolivar, $8^{\circ} 30^{\prime} \mathrm{N}, 63^{\circ} 45^{\prime} \mathrm{W}$, Anzoategui (MCNG 15276); 2 specimens (52,7-53,1 mm SL), on the Los Jabillos Creek S of El Pao, 88.5' N, 68¹1.5’ W, Anzoategui (MCNG 29483).

Astyanax caucanus (Steindachner, 1879): COLOMBIA: 3 specimens (71.4-94.1 mm SL), Caldas, La Dorada, Magdalena River Basin, Bocorná Creek, tributary of Guarinó River (ICN 10968); 2 specimens (68.2-69.0 mm SL), Caldas, La Dorada, La Victoria District ("corregimiento"), Magdalena River Basin, Guarinó River (ICN 11490); 1 specimen (75.9 mm SL), Caldas, La Dorada, La Victoria District ("corregimiento"), Magdalena River Basin, Casanquilla Creek tributary of Guarinó River, road La Dorada-Victoria (ICN 11522); 23 specimens (56.5-76.5 mm SL), 1 specimen C\&S (73.1 mm SL), Caldas, La Dorada, Magdalena River Basin, La Arenosa Creek, tributary La Miel 1 River (IAvHP 8439); 1 specimen (79.32 mm SL), Santander, Pie de cuesta, Magdalena River Basin, Chicamocha River, area of Pescadero (IAvHP 10568); 2 specimens (81.3-90.9 mm SL), Atlántico, Barranquilla, Magdalena River Basin, Canal del Dique (IUQ 171); 1 specimen (52.0 mm SL), 1 specimen C\&S (71.4 mm SL), Atlántico, Barranquilla, Magdalena River Basin, Suan (IUQ 1025); 3 specimens (61.1-61.9 mm SL), Atlántico, Barranquilla, Magdalena River Basin, El Jaguey, Dique Viejo, Canal del Dique (IUQ 1296).

Astyanax clavitaeniatus Garutti, 2003: GUYANA: 2 specimens (51.3-52.0 mm SL), Tukutu River at Moco-Moco Hydro Power Station 18.8 km SE of Lethem (AUM 37164); 2 specimens (51.3-52.0 mm SL), Tukutu River, Branco River, Negro River, creek between Lethem and Lake Amuku (AUM 45177).

Astyanax filiferus (Eigenmann, 1913): COLOMBIA: 1 specimen (71.3 mm SL), Caldas, Samaná River (ICN 15618); 8 specimens (59.4-89.2 mm SL), Puerto Cesár, Los Deseos Lake, La Dagua de Ibérico, Magdalena River Basin (CIUA 692); 2 specimens (71.4-83.9 mm SL), Caldas, La Miel River at La Cachaza, Norcasia (IUQ 2230); 1 specimen (79.1 mm SL), Caldas, La Miel River at La Cachaza, Norcasia (IUQ 2232); 3 specimens (74.3-91.1 mm SL), 2 specimens C\&S (67.3-70.0 mm SL), Boyacá, Palagua Creek, Puerto Boyacá, middle Magdalena River Basin (IAvHP 3969); 4 specimens (18.9-84.1 mm SL), 2 specimens C\&S (55.5-60.5 mm SL), Bolívar, canal Dique at Soplaviento (IUQ 988); 4 specimens (78.8-66.6 mm. SL), 2 specimens C\&S (39.6-78.4 mm SL), Bolívar, canal Dique at Soplaviento (IUQ 1019).

Astyanax incaicus (Tortonese, 1942): ECUADOR: 1 specimen (89.0 mm SL), Tunin Creek, Condor Canqui, Cenepa, Amazonas (MUSM 21090); 1 specimen (75.0 mm SL), Capitan Creek, Condor Canqui, Cenepa, Amazonas, 712 m a.s.l. (MUSM 21103); 1 specimen (74.9 mm SL), Creek Capitan, Condor Canqui, Cenepa, Amazonas, 707 m a.s.1. (MUSM 21309); 5 specimens (60.6-97.5 mm SL), 4 specimens C\&S (32.5-72.6 mm SL), locality Los Encuentros, Zamora-Chinchipe $3^{\circ} 45^{\prime} 50^{\prime \prime} \mathrm{S}, 7^{\circ} 37^{\prime} 30^{\prime \prime} \mathrm{W}, 750 \mathrm{~m}$ a.s.l. (MEPN 1974).

Astyanax lacustris (Lütken, 1875): BRAZIL: 4 specimens (63.9-75.0mm SL), 1 specimen C\&S (54.4 mm SL), Bahia, Riacho do Cinzeiro, a tributary to the Pira Lake (MNRJ 22804).

Astyanax maculisquamis Garutti \& Britski, 1997: BOLIVIA: 2 specimens (72.9-77.4 mm SL), Santa Cruz, Amboro national park (AMNH 233211); 5 specimens (43.3-72.2 mm SL), Ixiamas (CBF 2644); 2 specimens (53.1-61.1 mm SL), Madidi River (CBF 7282); 3 specimens (65.5-89.1 mm SL), Mamoré (CBF 1389); 10 specimens (48.8-61.9 mm SL), Ixiamas (CBF 2751); 10 specimens (45.9-68.8 mm SL), Eslabón River, La Paz (CBF 7936); 1 specimen (58.5 mm SL), Yapacani River, Santa Cruz (UF 167479); 1 specimen (74.6 mm SL), Puno department, Carabaya province Bujurqui Creek, Candamo River (MUSM 11855); 6 specimens (20.3-64.3 mm SL), Arroyo Tacuaral, Tohomonoco, 15²7'16.67" S, 67²6'54.47" W (UMSS 8938); 7 specimens (84.0-115.1 mm SL), Ichilo River, Mamoré River (UMSS 9239); 15 specimens (28.9-62.5 mm SL), Pto Santa Ana, Alto Beni, Madeira, $15^{\circ} 50^{\prime} \mathrm{S} 67^{\circ} 42^{\prime} \mathrm{W}$ (UMSS 9720); 8 specimens (93.6-104.4 mm SL), tributary Espiritu Santo, Paractito, $17^{\circ} 01^{\prime} 08^{\prime \prime} \mathrm{S}, 65^{\circ} 45^{\prime} 01^{\prime \prime} \mathrm{W}$ 
(UMSS 9194); 6 specimens (66.9-95.5 mm SL), Arroyo Tacuara, Tohomonoco, 15²7'16.67" S, 67²6'54.47" W (UMSS 10013); 17 specimens (35.4-106.5 mm SL), Arroyo Tohomonoco, cuartel Tohomonoco, $15^{\circ} 39^{\circ} 04^{\prime \prime} \mathrm{S}, 67^{\circ} 43^{\prime} 27 \mathrm{~W}$ (UMSS 9877); 10 specimens (29.9-49.6mm SL), Paraguá River, porvenir, 134ㄴ $1.74^{\prime \prime} \mathrm{S}, 61^{\circ} 52^{\prime} 1.75^{\prime \prime} \mathrm{W}$ (UMSS 3399); 8 specimens (29.9-51.7mm SL), Arroyo Popoy, Popoy, Alto Beni River, Madeira, 1532'0.41" S, 67²3'10.53" W (UMSS 10034). - BRAZIL: 4 specimens (63.2 mm SL), Abobral River (MUSM 17138); 2 specimens (28.4-83.3 mm SL), Rondônia,

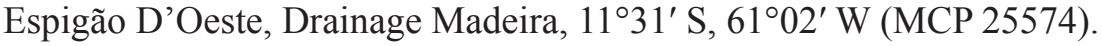

Astyanax magdalenae Eigenmann \& Henn, 1916 COLOMBIA: 7 specimens (53.5-66.7 mm SL), 2 specimens C\&S (47.6-51.0 mm SL), Córdoba, lake complex of lower Sinú River Sinú, Lorica (CIUA 470); 6 specimens (48.5-59.3 mm SL), Juan Esteban Creek, Magdalena River Basin, Santander (IAvHP 8185); 8 specimens (40.0-52.6 mm SL), Santander, Juan Esteban Creek, Magdalena River Basin (IAvHP 8186); 1 specimen (49.2 mm SL), Atlántico, small stream ("arroyo") in front of Santa Lucia (IUQ 1413); 2 specimens (50.9-52.6 mm SL), Caldas, Magdalena River, La Dorada (MPUJ 4221).

Astyanax sp. 8: COLOMBIA: 7 specimens (71.1-100.2 mm SL), Ranchería River, Guajira (ICN 9619); $2 \approx$ specimens (75.9-77.5 mm SL), Ranchería River,Guajira (ICN 9678); 1 specimen (102.3 mm SL), Tigre River, Córdoba (IMCN 3040); 2 specimens (108.11-110.20 mm SL), Ranchería River, Guajira (IUQ 715); 1 specimen (101.2 mm SL), Ranchería River, Guajira(IUQ 938); 5 specimens (60.5-86.0 mm SL), 2 specimens C\&S (73.1-75.3 mm SL), Ranchería River, Guajira (IUQ 1004); 1 specimen (69.1 mm SL), Ranchería River, Guajira (IUQ 1390).

Astyanax sp. 9: VENEZUELA (Zulia): 6 specimens (63.5-82.4 mm SL), 2 specimens C\&S (83.887.4 mm SL), El Padre Creek, Onia River, Escalante River, Maracaibo Lake, above road 2 at the town at km 35 (INHS 55460); 3 specimens (73.2-82.8 mm SL), Cachirí River, Maracaibo Lake (MBUCV 24776); 4 specimens (51.86-77.4 mm SL), 1 specimen C\&S (64.6 mm SL), Cachirí River, Maracaibo Lake (MBUCV 18265); 5 specimens (60.2-102.7 mm SL), Guasare, Maracaibo Lake (MBUCV 17027); 8 specimens (85.2-103.5 mm SL), Palmar River, Sierra de Perijá, Maracaibo Lake (MBUCV 23828); 5 specimens (51.6-81,3 mm SL), Catatumbo River, Maracaibo Lake (MBUCV 23790); 6 specimens (60.6-86.2 mm SL), Cachirí River, Maracaibo Lake (MBUCV 23827); 3 specimens (51.7-94.4 mm SL), Guasare River, Hacienda Pamplona, Guajira Municipality (UF 25431).

Astyanax poetzschekei Ahl, 1932: BRAZIL: 8 specimens (61.0-84.9 mm SL), 3 specimens C\&S (46.958.3 mm SL), Para River (AMNH 3779).

Astyanax rupununi Fowler, 1914: GUYANA: 4 specimens $(31.2-57.5 \mathrm{~mm} \mathrm{SL}), 2$ specimens C\&S (47.2-51.9 mm SL), Rupununi River, Essequibo River (AUM 37157); 5 specimens (44.7-50.3 mm SL), Takutu River, Branco River, Negro River (AUM 37161); 36 specimens (43.7-95.9 mm SL), 3 specimens C\&S (43.9-55.3 mm SL), Branco River, tributary Negro River (AUM 37984).

Astyanax siapae Garutti, 2003: VENEZUELA: 2 specimens C\&S (41.2-50.6 mm SL), Amazonas, Siapa River, Campamento Siapa II, drainage to the Casiquiare River, Negro River Basin (MBUCV 19445); 6 specimens (33.4-72.6 mm SL), 2 specimens C\&S (52.2-52.7 mm SL), Amazonas, Siapa River, small creek ("caño") between the Campamento Siapa I and Siapa II, drainage Casiquiare River, Negro River (MBUCV 19761); 6 specimens (30.3-54.4 mm SL), Amazon, Siapa River, aprox. 7 km upstream from River Campamento Siapa III, tributary Casiquiare River Basin, Negro River (MBUCV 20779).

Astyanax sp. 10: VENEZUELA (Bolívar): 3 specimens ( 38.8-54.4 mm SL), middle Claro River, at aquaduct, in isolated pools among rocks, Caroní River Basin (MCNG 18564); 3 specimens (58.2$65.5 \mathrm{~mm} \mathrm{SL}$ ), river aprox. $8 \mathrm{~km} \mathrm{~N}$ of Santa Elena at the Gran Sabana, Caroní River Basin (MCNG 18999); 11 specimens (20.2-57.5 mm SL), Morichal inundado aprox. $22 \mathrm{~km} \mathrm{~N}$ of Sta. Elena at Gran 
Sabana, Caroní River Basin (MCNG 19002); 7 specimens (50.7-58.6 mm SL), 4 specimens C\&S (39.4$70.4 \mathrm{~mm}$ SL), Tributary of Wará River, from the road exit to the airport (Fuerte Roraima), Caroní River Basin (MCNG 33923); 2 specimens (44.4-46.0 mm SL), Mapaurí River, at km 269 of the road to Santa Elena de Uairén at Gran Sabana,Caroní River Basin (MCNG 44878); 2 specimens (30.5-55.5 mm SL), small stream ("caño" or "quebrada") tributary of Sururon River at Gran Sabana, Caroní River Basin (MCNG 44887); 4 specimens (53.5-67.6 mm SL), El Venado Creek at Gran Sabana, Caroní River Basin (MCNG 44889); 2 specimens (28.6-61.3 mm SL), creek tributary of Kukenan River, at km 292, road 21 to Santa Elena de Uairén at Gran Sabana, Caroní River Basin (MCNG 44905); 1 specimen (50.6 mm SL), Uairén River at Gran Sabana,Caroní Basin (MCNG 44913); 3 specimens (44.7-51.5 mm SL), Caliope-wari River, between km 305-306, on the road to Santa Elena de Uairén at Gran Sabana, Caroní River Basin (MCNG 44916); 2 specimens (51.2-54.4 mm SL), creek at km 322 on the road to Santa Elena de Uairén at Gran Sabana, Caroní River Basin (MCNG 44922); 3 specimens (53.2-53.7 mm SL), 2 specimens C\&S (46.7-50.5 mm SL), Yuruaní River at $1.5 \mathrm{~km}$ of the Campamento de San Ignacio de Yuruaní at Gran Sabana,Caroní River Basin (MCNG 44928); 1 specimen (33.5 mm SL), at km 254, $4 \mathrm{~km}$ NE of San Ignacio, Caroní River Basin (MCNG 48071); 2 specimens (50.5-68.7 mm SL), San Ignacio River at km 258, Caroní River Basin (MCNG 48073).

Astyanax sp. 11: VENEZUELA (Bolívar): 12 specimens (27.8-57.1 mm SL), Cuyuni River Basin (MCNG 42655); 2 specimens (43.0-45.4 mm SL), Parupa River, at $200 \mathrm{~m}$ of the Campamento Parupa, road to Luepa, at km 146-147 (MCNG 44973); 4 specimens (48.3-54.8 mm SL), 3 specimens C\&S (34.5-42.2 mm SL), $5.5 \mathrm{~km}$ behind the camping site Parupa, road to Luepa (MCNG 44979); 6 specimens (50.1-62.9 mm SL), Parupa River (MCNG 44982); 1 specimen (62.0 mm SL), Kama-Merú River (MCNG 44990); 2 specimens (42.3-45.2 mm SL), Bolívar, Sacaica River, between km 180-181, road to Campamento Luepa (MCNG 44997); 1 specimen (46.6 mm SL), Parú-Mareman River, at $52 \mathrm{~km}$ of Kama-Merú River, road to Campamento Luepa (MCNG 45009); 2 specimens (48.0-53.3 mm SL), $2.5 \mathrm{~km}$ behind Campamento Parupa, road to Luepa (MCNG 45112).

Astyanax sp. 12: ECUADOR: 2 specimens (46,5-56,7 mm SL), Pastaza River, Solimões, Pastaza, 1'55,63' S, 77²48,63' W (MBUCV 32513). - PERU: 2 specimens (72.7-89.6 mm SL), Loreto department, Ucayali province, Sierra de la Contamana, Contamana, Aguas Frías Creek lower part, Ucayali River Basin (MUSM 17638); 2 specimens (73.8-75.0 mm SL), Loreto, Ucayali, Sierra de Contamana, Contamana, Aguas Frías Creek lower part, Ucayali River Basin (MUSM 17639); 5 specimens (72.9$76.1 \mathrm{~mm}$ SL), Loreto, Sierra de la Contamana, Contamana, Aguas Frías Creek middle part, Ucayali River Basin (MUSM 17606); 2 specimens (69.1-75.7 mm SL), Loreto, Ucayali, Sierra de la Contamana, Contamana, lower upper reach of Aguas Frías Stream ("quebrada"), Ucayali River Basin (MUSM 17649); 8 specimens (65.4-93.4 mm SL), Loreto, Ucayali, Sierra de la Contamana, Contamana, Aguas Frías Creek, Carachammita Creek, Ucayali River Basin (MUSM 17626); 1 specimen (77.4 mm SL), Loreto, Ucayali, Sierra de Contamana, Contamana, Aguas Calientes Creek upper part, Ucayali River Basin (MUSM 17601); 3 specimens (75.0-76.9 mm SL), 1 specimen C\&S (72.2 mm SL), Tambopata, Madre de Dios River, Palmichal, Madre de Dios (MUSM 16514); 4 specimens (70.2-78.7 mm SL), Loreto, Maynas, Ucayali, Contamana, Aguas Frías Creek (MUSM 17648); 1 specimen (79.8 mm SL), 2 specimens C\&S (57.5-78,0 mm SL), Loreto, Itaya River, Peruvian Amazonas River Basin (INHS 39933); 5 specimens (36.8-53.8 mm SL), Loreto, Alto Amazonas, Pastaza River, Peruvian Amazon River Basin Solimões, 39,95' S, 76 25,30' W (MBUCV 32556); 3 specimens (37.1-46.5 mm SL), 2 specimens C\&S (37.6-48.4 mm SL), Pastaza River, Solimões, Pastaza, 328.28' S, 76²17.11' W (MBUCV 32586).

Astyanax utiariti Bertaco \& Garutti 2007: BRAZIL: 3 specimens (42.8-50.1 mm SL), 2 specimens C\&S (41.9-50.7 mm SL), Buriti, Tapajós, Mato Grosso (MCP 42715). 
RUIZ-C. R.I. et al., Revision of the Astyanax orthodus species-group

Astyanax sp. 14: PERU: 1 specimen (108.5 mm SL), Madre de Dios, Manu, Manu National Park, Pakitza, Manu River (MUSM 2457); 3 specimens (38.6-47.6 mm SL), Madre de Dios, Manu, Culli Creek, Alto Madre de Dios River, Madre de Dios River Basin (MUSM 3814); 2 specimens C\&S (45.685.4 mm SL), Madre de Dios, Manu, Manu National Park, Pakitza, Picaflor stream, Madre de Dios River Basin (MUSM 3822); 1 specimen (88.7 mm SL), Madre de Dios, Manu, Manu National Park, Pakitza, Trompetero Creek (MUSM 3848); 3 specimens (98.3-81.9 mm SL), Madre de Dios, Manu, Manu National Park, Pakitza, Picaflor Creek, Madre de Dios River Basin (MUSM 4662); 1 specimen (56.0 mm SL), 2 specimens C\&S (45.2-78.6 mm SL), Madre de Dios, Manu, Manu National Park, Pakitza, Martin Pescador stream, Manu River, Madre de Dios River Basin (MUSM 9076); 1 specimen (50 mm SL), Puno, Sandia, Tavara River (MUSM 46848).

Argopleura magdalenensis (Eigenmann, 1913): COLOMBIA: 8 specimens, Valle del Cauca department, Tulua municipality, Carmelita locality, Cauca River Basin, Portugal de Piedras River $1 \mathrm{~km}$ before mouth in Cauca River, $4^{\circ} 03^{\prime} 46^{\prime \prime} \mathrm{N}, 76^{\circ} 18^{\prime} 44.9^{\prime \prime}$ W. 962 m a.s.l. (IUQ 3109); 2 specimens C\&S, Quindio Department, Quimbaya municipality upper Cauca River, La Vieja River in La Española locality (IUQ 1576); 2 specimens C\&S, Quindio Department, Quimbaya municipality, upper Cauca River, La Vieja River in Buenavista Creek (IUQ 691).

Bryconamericus thomasi Fowler, 1940: BOLIVIA: 3 specimens, Amazon Basin, del Plata/Bermejo, Grande de Tarija/Tarija, Saykan River (UMSS 04968); 6 specimens, Amazo, Itenez, San Pablo/Parapeti, Heredia River (UMSS 00891); 7 specimens C\&S, Del Plata/Bermejo Emborozo River (UMSS00740).

Carlastyanax aurocaudatus (Eigenmann, 1913): COLOMBIA: 2 specimens, Quindio, Armenia municipality, Fachada locality, Upper Cauca River, La Vieja River, Bambuco Creek sector Colegio San Jose (IUQ 3494); 4 specimens C\&S, Quindio state, Circasia municipality, La Siria locality, Cauca River, La Vieja River, El Roble River Basin, La Siria Creek, 4³5'19" N, 7542'39" W, 1470 m a.s.l. (IUQ 866).

Hemibrycon boquiae (Eigenmann, 1913): COLOMBIA: 2 specimens C\&S, Caldas state, Neira municipality, Tareas locality, Cauca River, Tareas River to $100 \mathrm{~m}$ from road Neira to Salamina, $5^{\circ} 12^{\prime} 04^{\prime \prime}$ N, 75²3' $56^{\prime \prime}$ W, 1286 m a.s.l. (IUQ 492); 3 specimens C\&S, Quindio Department, Salento municipality, Boquia locality, upper Cauca River,La Vieja River Basin, Boquia Creek tributary of Quindio River (IUQ 2633); 5 specimens C\&S, Quindio state, Salento municipality, Boquia locality, upper rio Cauca,

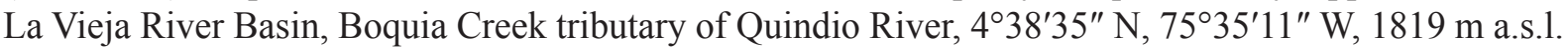
(IUQ 2681); 2 specimens C\&S, Quindio state, Salento municipality, on the road to Boquia locality, upper Cauca River, La Vieja River Basin, Villa Paola Creek tributary of Quindio River (IUQ 547).

Hemibrycon polyodon (Günther, 1964): ECUADOR: 1 specimen C\&S, Napo-Sucumbios province, Estero Venado, Coec River $3 \mathrm{~km}$ down stream from campsite (IUQ 3586); 9 specimens, ZamoraChinchipe province, San Antonio Creek, 21 Mar. 1979 (MEPN 1533).

Hyphessobrycon bifasciatus Ellis, 1911: BRAZIL: 3 specimens, Rio de Janeiro state, Município de Casemiro de Abreu, original course of rio São João, south of Professor Souza, 22 32'11" S, 42 ${ }^{\circ} 8^{\prime} 8^{\prime \prime}$ W (MNRJ 42997).

Knodus carlosi Román-Valencia 2003: PERU: 34 specimens, Cusco department, La Convencion province, Echarate district, lower Urubamba River, Katshingari creek, Upper Ucayali River Basin 478 m a.s.l. (MUSM 31463); 43 specimens, Loreto state, Amazon, Marañon River drainage (MUSM 3811). - ECUADOR: 1 specimen C\&S, Sucumbios province, Tiputine River (IUQ).

Tetragonopterus argenteus Cuvier, 1816: COLOMBIA: 11 specimens, Putumayo department, Amazon, Puerto Leguizamo municipality, in front of Santa Belen de Yaricaya, Yaricaya creek tributary of Putumayo river (ICNMNH14384). 